\title{
The Wondrous Bird's Nest I
}

Hans jacob Christoffel von Grimmelshausen

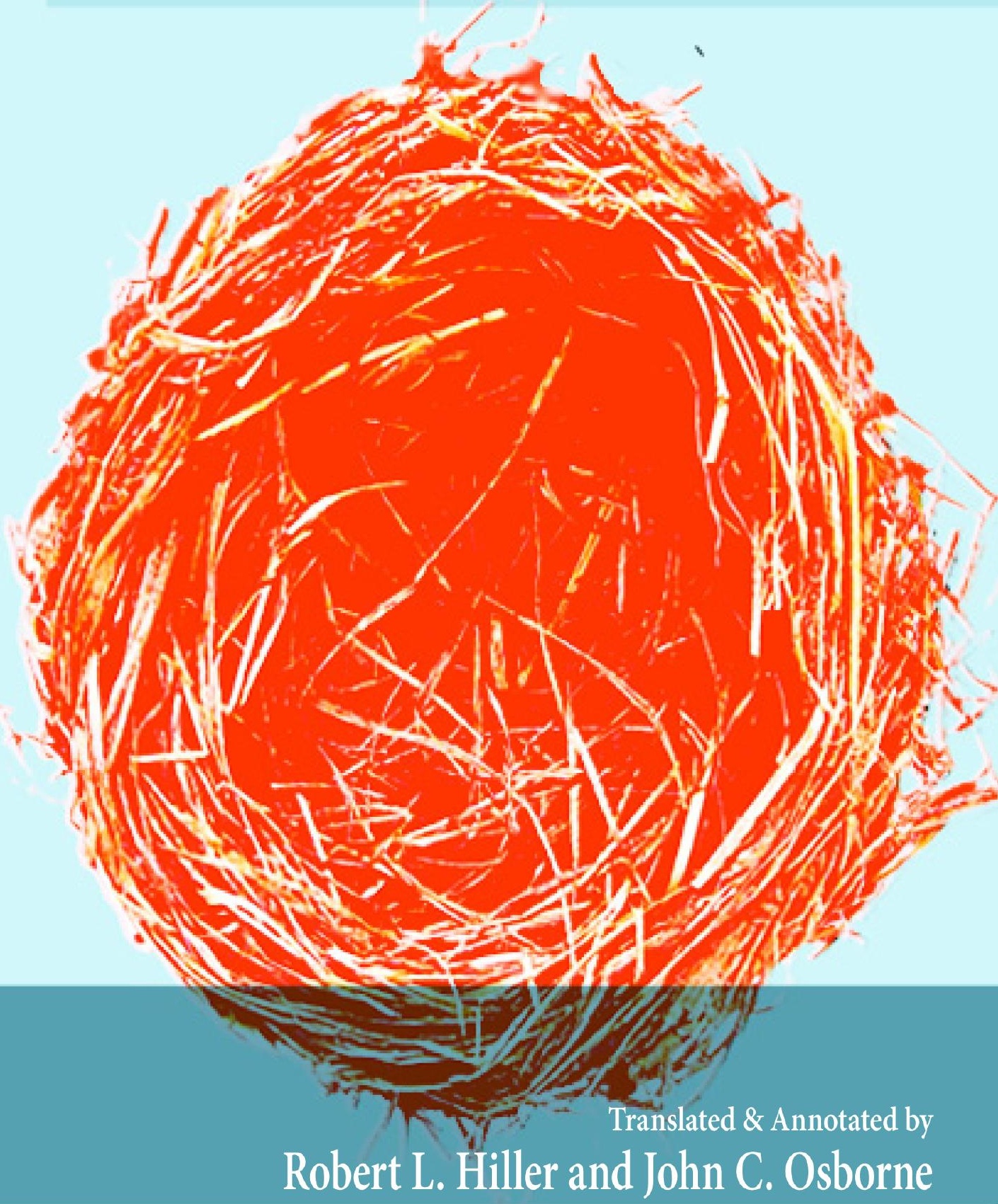



The Wondrous Bird's Nest I 



\section{The Wondrous Bird's Nest I}

Hans Jacob Christoffel von Grimmelshausen

Translated \& Annotated by

\section{Robert L. Hiller and John C. Osborne}




\section{The Wondrous Bird's Nest I}

(C) 2011 by Ute Stargardt and Martha Lee Osborne

Digital version at www.newfoundpress.utk.edu/pubs/hiller

Newfound Press is a digital imprint of the University of Tennessee Libraries. Its publications are available for non-commercial and educational uses, such as research, teaching and private study. The author has licensed the work under the Creative Commons Attribution-Noncommercial 3.0 United States License. To view a copy of this license, visit http://creativecommons.org/licenses/by-nc/3.0/us/

For all other uses, contact:

Newfound Press

University of Tennessee Libraries

1015 Volunteer Boulevard

Knoxville, TN 37996-1000

www.newfoundpress.utk.edu

ISBN-13: 978-0-9846445-0-6

ISBN-10: 0-9846445-0-4

Grimmelshausen, Hans Jakob Christoph von, 1625-1676.

[Wunderbarliche Vogelnest I. English]

The wondrous bird's nest I / Hans Jacob Christoffel von Grimmelshausen ;

translated \& annotated by Robert L. Hiller and John C. Osborne. xxxiv, 190 p. : digital, PDF file.

Translation of: Wunderbarliche Vogelnest I.

Includes bibliographical references.

1. Thirty Years' War, 1618-1648 - Fiction.

I. Hiller, Robert Ludwig, 1915- II. Osborne, John C., 1928- III. Title. PT1731.A4 E588 2011

Book design by Jayne W. Rogers

Cover design by Andrea E. Markel 


\section{contents}

Chronology of Grimmelshausen's Works................... ix

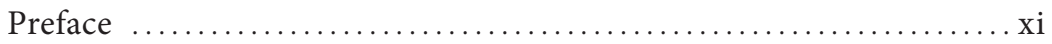

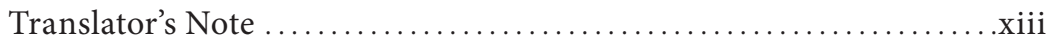

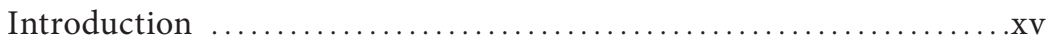

Foreign Words and Phrases Used in the Text $\ldots \ldots \ldots \ldots \ldots \ldots \ldots$............

The Wondrous Bird's Nest

by Michael Rechulin von Sehmsdorff

The Ballad of the Wondrous Bird's Nest

Chapter One: [Michael comes by the wondrous bird's nest, becomes invisible, and uses his belly gases to gain his freedom.] .......1

Chapter Two: [Sir Pnnlss goes a-wooing for a wealthy wife, or: The

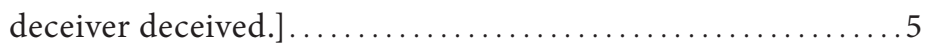

Chapter Three: [Sir Pnnlss' screams and what they mean; item, a breakfast with a band of beggars.] .................... 15

Chapter Four: [Two Capuchins and a parson's wife, a disputation between Calvinists and Catholics, and the miraculous chastisement of a blasphemer.]

Chapter Five: [A skinflint's plans are thwarted by a seduction, and Michael repays the skinflint's wife for flavoring her cheese.]....33

Chapter Six: [May bewails the passing of December, and Michael is mistaken for December's ghost.]

Chapter Seven: [The ardor of a parson who would seduce a young married woman is cooled in a right merry way, and Michael runs afoul of hobgoblins in the winecellar.]. 
Chapter Eight: [A disputatio on Pre-Adamites, and how two studiosi are saved from certain death.] .........................53

Chapter Nine: [Michael is an unseen wedding guest and witnesses the devil being put into hell.] ........................61

Chapter Ten: [A visit to a rich man's house, and a vain young lady's fright at what she sees in her mirror.]

Chapter Eleven: [Michael saves a poor man's nanny, feeds his starving family, and comes to understand Simplicissimus' symbolum.] ..73

Chapter Twelve: [Michael sees a thief sell a cow back to its rightful owner, and is the unwilling judge of lovemaking both upstairs and below stairs, before he intercedes to prevent robbery and murder.]

Chapter Thirteen: [A shepherd and his wife cheat their master, and the miraculous transformation of a ham into a shoe effects the reform of a dishonest innkeeper.] ...................91

Chapter Fourteen: [Michael gets a new pair of shoes and hears of a plot against young Simplicissimum, which plot, however, he is unable to foil.]

Chapter Fifteen: [The cow thief and murderer gets his just deserts, an innkeeper misinterprets the actions of young Simplicissimi and the innkeeper's wife, old Simplicissimus vents his spleen against the learned author of Asenath, and Michael sees to it that young Simplicissimus is exonerated of a charge of lechery.]

Chapter Sixteen: [Michael hears a golden rule and warning from the mouth of a peasant lad and punishes a cavalier for trying to do to a cobbler's wife what the cobbler had done to the cavalier's shoe.]

Chapter Seventeen: [Michael is witness to a palm-greasing but cannot decide whom to punish.] 
Chapter Eighteen: [A right tall tale about an encounter with a wolf; Michael seduces a maiden while both are flushed with drink.] .. 129

Chapter Nineteen: [Michael prevents a herdsman from committing a sin which cries to heaven and realizes that the salvation of his own soul is on shaky underpinnings.]................. 135

Chapter Twenty: [Michael is punished by a swarm of bees and casts away his wondrous bird's nest, only to see another poor sinner come into possession of it.] .........................141

Short References and Abbreviations Used in the Notes ........... 155

Notes: Title Page .......................................... 157

Notes ................................................... 159

Bibliography ......................................... 185 



\section{Chronology of Grimmelshausen's Works*}

Note: included for each work is the German short title, the nom de plume (in parentheses), and the English short title (in brackets).

1666 Satyrischer Pilgram I (Samuel Greifnson von Hirschfeld), [The Satirical Pilgrim, Part I]

Der keusche Joseph (Samuel Greifnson von Hirschfeld), [Chaste Joseph]

1667 Satyrischer Pilgram II (Samuel Greifnson von Hirschfeld), [The Satirical Pilgrim, Part II]

1668 Simplicissimus I-V (German Schleifheim von Sulsfort), [Simplicissimus]

1669 Die Continuatio [Simplicissimus VI] (German Schleifheim von Sulsfort), [Continuatio]

1670 Dietwald und Amelinde (H. J. Christoffel von Grimmelshausen), [Dietwald and Amelinde]

Ratio Status (Hans Jacob Christoph von Grimmelshausen), [Ratio Status]

Landstörtzerin Courasche (Philarchus Grossus von Trommenheim), [Runagate Courage]

Der seltzame Springinsfeld (Philarchus Grossus von Tromerheim), [Heedless Hopalong]

Der erste Beernhäuter (Illiteratus Ignorantius), [The First Sluggard]

${ }^{*}$ Not listed are the various Europäische Wundergeschichten-Calender [European Calender of Wondrous Stories], the authorship of which is now disputed. 
1670 (continued)

Simplicissimi Gauckeltasche (Illiteratus Ignorantius), [The

Simplicissimi Magic Book]

Musai (Samuel Greifnson von Hirschfeld), [Musai]

1671 Der ewigwährende Calendar (Simplicissimus)] [The Perpetual Calender]

1672 Rathstübl Plutonis (Erich Stainfels von Grufensholm), [Plutus' Council Chamber]

Die verkehrte Welt (Simon Lengfrisch von Hartenfels), [The Topsy-Turvy World]

Proximus und Lympida (H. J. Christoffel von Grimmelshausen), [Proximus and Lympida]

Das wunderbarliche Vogelnest I (Michael Rechulin von Sehmsdorff), [The Wondrous Bird's Nest, Part I]

Der stoltze Melcher (no author given), [Proud Melcher]

1673 Der Teutsche Michel (Signeur Messmal), [German Michel]

Der Bartkrieg (no author given), [The War of the Beards]

Das Galgen-Männlin (Israel Fromschmidt von Hugenfelss), [The Mandrake]

1675 Das wunderbarliche Vogelnest II, [The Wondrous Bird's Nest, Part II] 


\section{Preface}

The Wondrous Bird's Nest is the fourth of the five novels by Hans Jacob Christoffel von Grimmelshausen which constitute the socalled Simplician cycle. The longest and most famous novel of the cycle, Simplicissimus, has long been acclaimed as the first great German novel, and several English translations of it are available. Our own renderings of the next two volumes, The Runagate Courage and Heedless Hopalong, presented them to the Englishspeaking public. The Wondrous Bird's Nest is a complete and fully annotated version of Das wunderbarliche Vogelnest. Within the next few years we hope to complete our translation of the remaining novel, The Wondrous Bird's Nest, Part II, so that the entire Simplician cycle, one of the most significant and delightful groups of prose fiction works in world literature, will be available in English translation. 



\section{Translators' Note}

The Wondrous Bird's Nest is based primarily on J. H. Scholte's edition of the first edition (1672) of Grimmelshausen's Das wunderbarliche Vogelnest, but the texts and notes of a number of other editions were consulted (See Bibliography, Part A). In order to preserve as much as possible the flavor of the German original, we have chosen, as we did in our translations of Die Landstörtzerin Courasche (The Runagate Courage, Lincoln, Nebraska: University of Nebraska Press, 1965) and Der seltzame Springinsfeld (Heedless Hopalong, Detroit, Michigan: Wayne State University Press, 1981), to leave most of the many foreign words and phrases in the text untranslated, and to retain the "Baroque" sentence structure and rhetorical flourishes whenever they do not obscure the meaning. Even though in virtually all instances the meaning of the foreign words and phrases should be obvious from the context or from English cognates, a list of them and their English equivalents precedes the text.

The vagaries of seventeenth-century spelling of proper names have been retained in the Chronology of Grimmelshausen's works, the Notes, and the Bibliography. Thus there may be several variations in the spelling of a single name.

Although the narrative in the editio princeps is uninterrupted, we have divided it into twenty chapters as all modern German editions do. We have also supplied short chapter headings, which is not customary in German editions but which may be of help to the reader who is searching for a specific episode.

Notes to the text, arranged by chapter, are appended. A list of the short titles of the secondary works cited precedes the Notes. 
References to works by Grimmelshausen are given by book and chapter, so that any edition may be consulted. All translations from German in the Notes are our own. 


\section{introduction}

\section{The Wondrous Bird's Nest}

The Wondrous Bird's Nest, the fourth of the five Simplican novels, first appeared in late 1672 and, like the three earlier works-Simplicissimus, The Runagate Courage, and Heedless Hopalong-suffered the fate of almost all literary successes of the time: it was immediately pirated. The legitimate publisher countered by issuing a reprint of the novel which was like the editio princeps in almost every respect, except that it listed the place of publication as Amsterdam instead of Monpelgart. Shortly after the reprint appeared, yet another edition of the novel was put out, either by the pirater of the original edition or by some other publisher bent on capitalizing on the novel's popularity. Thus, within about two years no fewer than four editions of The Wondrous Bird's Nest were made available to the German reading public.

The popularity of the work derived in large measure from the success of the earlier novels in the Simplician cycle, and either Grimmelshausen or his publishers obviously made a conscious effort to associate in the public's mind The Wondrous Bird's Nest with the earlier works. The very title of the novel indicated that it was a sequel to Heedless Hopalong, for Hopalong, his hurdy-gurdy girl, and her bird's nest were all prominently mentioned. Moreover, an attempt was made to link the work to Simplicissimus in ways both blatant and subtle. The title page proclaimed that this work was written "in the Simplician manner," and the more observant reader could not fail to note that the alleged publisher, Johann Fillion of Monpelgart, was the same one who had first put out Simplicissimus. Moreover, the name of the alleged author of The Wondrous Bird's Nest, Michael 
Rechulin von Sehmsdorff, was an anagram of German Schleifheim von Sulsfort (the alleged author of Simplicissimus), Melchior Sternfelß von Fuchshaim (Simplicissimus' given name), and Samuel Greifnson von Hirschfeld (identified in the Beschluß to Simplicissimus as the real name of its author). All these names, as scholars were to realize only more than a century later, were also anagrams of Hans Jakob Christoffel von Grimmelshausen.

\section{The Wondrous Bird's Nest and the Other Simplician Novels}

The Wondrous Bird's Nest is, in fact, similar in many ways to the three earlier works to which its title page referred. Like two of them, it arises from the preceding novel in the cycle, in this instance Heedless Hopalong. The narrator-hero is the same young halbardier who snatched the hurdy-gurdy girl's wondrous bird's nest as it was falling to earth and, because of its magic powers, was forthwith rendered invisible to his comrades. And like all three of the earlier novels, it leads into the next novel in the cycle. Michael, the hero, describes how the nest falls into the hands of its next owner. As in Runagate Courage and Heedless Hopalong Grimmelshausen's finest literary creation, Simplicissimus, appears as an active character. Like all three of the earlier Simplican novels, The Wondrous Bird's Nest is related in the first person by a fictitious narrator and may seem, at first glance at least, to be a typical picaresque novel. Like them it presents vivid descriptions of everyday life and of a host of different human types. And like them it is written in artless colloquial language which renders all the more effective those few passages which are in the stilted style of the chancellory, the florid language of the marinist novel, and the pathetic and pseudo-Biblical tone of the sermon and homily. 
There are, however, significant differences between The Wondrous Bird's Nest and the earlier Simplician novels. First of all, it was not broken down into chapters with short headings, as were the other Simplician works. This difference must have been felt strongly, at least by the Felßeckers, for in their editions of the collected works of Grimmelshausen they divided The Wondrous Bird's Nest into twenty chapters, but without chapter headings, a convention which almost all modern editors, except those who reproduce the editio princeps, have followed.

A second difference is strongly implied by the frontispiece illustration of the novel. The comparable illustrations to The Runagate Courage and to Heedless Hopalong depict the protagonists of the works, together with some objects of symbolic significance, and the dominant figure in the frontispiece illustration of Simplicissimus is the phoenix. The Wondrous Bird's Nest, by contrast, was preceded by a copper etching portraying two figures, a child looking through a telescope at a pile of masks, and a satyr holding behind him in one hand a mask and before his eyes with the other hand the wondrous bird's nest. To seventeenth-century readers, who were accustomed to and sensitive to the emblematic and symbolic importance of book illustrations, this picture referred not to the three earlier Simplician novels (even though the phoenix in Simplicissimus does have one satyr's foot), but to Grimmelshausen's very first published work Der satyrische Pilgram (which can be translated either The Satirical Pilgrim or The Satyr's Pilgrim), for which an illustration was chosen which also depicted two figures, a satyr and a pilgrim. The satyr and the pilgrim illustrate an anecdote which Grimmelshausen recounts in the introduction to The Satirical Pilgrim about a "satyr who chased away a pilgrim to whom he had before amiably given lodging for no other reason than that he /the pilgrim/ had breathed on his frozen hands to make them warm and had then blown on the hot food to make it 
cold." Grimmelshausen goes on to explain that his intent is to honor the satyr's pilgrim by demonstrating that everyone and everything can be viewed by a single person in two different ways, a positive and a negative one, because “except for God's almighty goodness, which is divine, there is nothing in the whole world which is perfect and without flaws, nor, on the other hand, is there any creature or thing (except for the wretched devil and his followers) which is so bad that it does not have something about it which should be praised." In The Satirical Pilgrim Grimmelshausen treated twenty general topics. Each discourse was divided into three parts: a Satz, which listed everything good about the subject; a Gegensatz, which described everything bad about it; and a Nachklang, in which the author voiced his own "unauthoritative" opinion. The illustration to The Wondrous Bird's Nest may therefore be a warning to the reader that it is a different sort of work than the three earlier novels, perhaps one which will focus more on general problems of concern to all mankind than on the specific adventures and misadventures of its protagonist.

An examination of the text of The Wondrous Bird's Nest reveals yet other differences. In the three earlier Simplican novels a world at war formed the backdrop of the adventures of the protagonist. In The Wondrous Bird's Nest the world portrayed is one at peace, and Grimmelshausen presents a panoramic view of this world, with its landscape of open fields, woods, and forests dotted with solitary farms, cottages, monasteries, villages, and towns. And in terms of space and time this world is quite different from the one depicted in the earlier novels. Even though Grimmelshausen sometimes avoided identifying specifically where and when Simplicissimus, Courage, and Hopalong experienced their various adventures, the inordinate number of place names and historical events which are mentioned make it easy to determine the time and place of virtually every action. In The Wondrous Bird's Nest, however, both time and place are kept quite 
vague. We know from Heedless Hopalong that the action must begin in Munich in June of 1669 and from The Wondrous Bird's Nest, Part II, that the action ends on August 24 of presumably the same year, but the only indication of historical time in The Wondrous Bird's Nest is a single reference to the war between the Duke of Lorraine and the Count Palatine which took place in 1668-1669. Moreover, the hero-narrator gives no indication of how long his journey lasted. We know only that it took place during the summertime. Nor do we know precisely where his travels took him, only that he reached a region which was already Polish territory but where German was still spoken, and then turned back and hurried homeward.

The hero-narrator of The Wondrous Bird's Nest is quite different from Simplicissimus, Courage, Hopalong, and even Philarchus, the alleged narrator of the adventures of the latter two. We learn nothing whatsoever about his ancestry, his family, his education or lack thereof, and his social status-factors which Grimmelshausen is careful to mention in his portrayals of Simplicissimus, Courage, and Hopalong. We do not even know what trade he plied before the bird's nest fell into his hands. Some critics have called him a lansquenet, and it is true that on his first appearance, in both Heedless Hopalong and The Wondrous Bird's Nest, he is one of a group of "twelve hearty men with halberds" who have been sent to capture the hurdy-gurdy girl, but he may well be simply a young man who has been deputized for one specific and isolated police action. Only twice does he give any indication of knowledge of things military, once when he refers to a capitano and his tirones and a second time when he mentions "the Swedish war," but the former could well be second-hand knowledge, and he could not possibly have had any first-hand knowledge of the latter, for he could scarcely have been born before the end of the Thirty Years' War. We do know his name from the title page, but from his tale we learn only that he is young, rather intelligent, a 
bit proud of some bits and pieces of erudition he has gathered from somewhere and of some slight knowledge of Latin, French, and Italian, and that he is a strong lad who in his home town was called "Mighty Mike." Moreover, we never learn what he looks like. This is all the more surprising because Grimmelshausen, although he was not as skillful or as interested in describing the physical appearance of his major characters as one might perhaps wish, nevertheless included some splendid descriptions of them, particularly those given by Philarchus in The Runagate Courage and Heedless Hopalong. Not so with Michael. We do not know whether he is tall or short, fat or thin, blond or brunette, handsome or ugly. He remains as invisible to us as he is to his fellow man.

Michael's invisibility, perhaps the crucial difference between him and the other protagonists, is one of Grimmelshausen's most fortuitous inventions. Because his fellow men cannot see him, Michael, like the satyr of the frontispiece, is able to perceive the world unmasked, to observe people who, thinking themselves unobserved, put aside the masks they show the world and reveal their true selves. Through Michael's eyes, for example, we see an impoverished nobleman attempt to conceal his true condition and marry into a family which he takes to be wealthy but which really has as little money as he does; we hear a skinflint peasant who has kept his grown children in bondage ponder on how he can foil his daughter's plans to marry; we watch a shepherd and his wife joke about the way they are cheating their master, and an innkeeper decide to strengthen his wine, which he has so watered down that his guests refuse to drink it. Even the most intimate situations are not hidden from Michael. He looks on as a parson attempts to seduce a young married woman, and as a peasant lad succeeds in seducing his bride-to-be. He is an invisible witness to the lovemaking of a merchant and his wife, and of the hired man and the servantmaid who work for them. And he is 
present when a cavalier and a cobbler's wife are quick to take advantage of the cobbler's absence.

One decided advantage of Michael's invisibility is that it affords him access to virtually every level of society. He can enter the most luxurious mansion and the most wretched cottage with equal ease, and as a consequence he is able to watch and listen to the high and the mighty, the low and the humble, the rich and the poor, to men and women, to young and old, to respectable folk and vicious criminals. He is present when two clergymen plot the downfall of a rival, when beggars boast of their cheats and deceits, when a mayor's wife accepts a bribe for her husband, and when two thieves plan to rob and, if necessary, to murder a wealthy merchant. In contrast to Simplicissimus, Courage, and Springinsfeld, and to nearly all heroes of the picaresque novel from Lazarillo to the present, Michael enjoys absolute social mobility, and his tale, on one level, is a penetrating satire on the follies, vices, and immorality of men and women in all walks of life.

The Wondrous Bird's Nest, however, is more than a clever social satire, for Michael's invisibility, which conceals the "outer man" from us, serves to focus attention on the "inner man." We soon begin to see this "inner man" quite clearly, even down to his vital organsparticularly his stomach, with which he has a very special relationship, to whose grumblings, complaints, and commands he listens and pays heed, and to which he carefully attends when he has overindulged, which, alas, happens all too often. But not only his stomach, which would remain concealed even if he were visible, is revealed to us; we also see that part of him which is truly invisible: his mind. More importantly, we observe how his very invisibility, which cuts him off from the rest of mankind but makes it possible for him to see so much that is hidden from others, not only puts him in the position to judge the actions of others, but also slowly and inexorably compels 
him to turn his eyes inward, to examine and judge his own thoughts, ideas, and motives, and, ultimately, to come to some understanding of what is every human being's invisible but most prized possession: the immortal soul. Thus on one level The Wondrous Bird's Nest is the story of an inner journey, one which is by no means as aimless as the journey taken by the "outer man" and by the "world" in the frontispiece illustration.

\section{Structure and Form}

The failure of most critics to recognize the significance of Michael's inner journey has led them to consider the structure of The Wondrous Bird's Nest primarily in terms of the external events which are described, and to characterize the work as a loose collection of anecdotes, or even as a cycle of novellas. More sensitive and perceptive critics have recognized that the novel is by no means a rambling, aimless tale, but a cleverly constructed narrative which reflects the twisting and turning path the "world" pursues and at the same time portrays, in a succession of ascending stages, the education of the hero-narrator. Michael's education is in the form of a journey which is similar to that taken during the sixteenth and seventeenth centuries by a young gentleman after he had concluded his formal studies: the Grand Tour, the Bildungsreise, from which the traveler was expected to return prepared to assume the responsibilities which society imposed upon him.

There is one rather clear indication that Grimmelshausen intended The Wondrous Bird's Nest to consist of two parts of almost exactly equal length. In the editio princeps, probably the only edition whose printing Grimmelshausen supervised, there is one paragraph, in the very middle of the novel, which is set off from the text which precedes and follows it: the paragraph in which reference is made, 
for the first time in the novel, to Simplicissimus, and in which the narrator cites Simplicissimus' motto "Perception deceives" (the last paragraph in Chapter 11). The adventures in the text leading up to this paragraph have led Michael, little by little, to this insight, which he must first possess if he is to continue his "inner journey" to the desired conclusion. Closer examination of the narrative up to this point reveals that it, in turn, is divided into two sections of nearly equal length (in terms of pages).

In the first section, the first quarter of The Wondrous Bird's Nest (Chapters 1-5), Michael is still testing the powers of the bird's nest. As yet he has no plans as to how to use the invisibility it affords him; he has only the vague notion that with it he can lead a life of ease and luxury. This phase of his development ends with his theft of a satchel in which he can carry his loot. Whenever he physically intrudes into a situation - such as when he knocks down a Calvinist who has blasphemed the Virgin Mary, and when he punishes an old woman for moistening heads of cheese with her own urine-he does so in anger, instinctively, and he seldom reflects on his actions.

Michael's innate sense of morality only begins to assert itself in the second section of the novel (Chapters 6-11). He begins to consider himself too good to be a purse-snatcher and common thief, and decides to steal only from usurers and money lenders. Furthermore, he now begins to act with more discernment and deliberation, motivated not by anger but by a sense of justice and morality. He saves a young married woman from seduction and two students from death, and he bestows money and food on a poor cottager and his family. Finally, he reflects more and more on what he has experienced. When a young wife breaks into tears and begins to shriek after she has been told that her aged husband will certainly soon die, Michael realizes that he would have interpreted these actions as signs of genuine grief if he had not only moments before heard the young woman say 
that she is really perturbed at losing her fine house and life of ease. The two students' completely erroneous conjectures about how they came to be saved from death make clear to Michael the absurdity of man's ideas about events which defy easy rational explanation. And when he considers that the young lady who saw his face in the mirror while she was primping took him to be an evil spirit, while the poor cottagers whom he aided regarded his actions as coming from God, he becomes keenly aware of how great the impact of circumstance and individual subjectivity is upon human judgments. Now he cannot but agree with old Simplicissimus that "Perception deceives."

The narrative after the central paragraph also consists of two parts of nearly equal length which may be called the third and fourth sections of the novel. In the third section (Chapters 12-16) Michael begins to realize that his way of life is reprehensible, and he consciously attempts to use his invisibility to right wrong, prevent crime, reward good, and punish evil. He now decides not to steal money from any Christian, but instead to go to Poland and rob a rich Jew, and on the way he intends to take only what he needs to feed and clothe himself. Of course, he still on occasion acts unthinkingly, as when he takes a ham from a stewpot and puts in its place his shoe. Moreover, while trying to punish and reward, he accidentally and thoughtlessly does harm to others. In successfully foiling the attempt of the thieves to rob a merchant, Michael incurs guilt, as he realizes, when one of the thieves dies unshriven, and while his letter to the judge exonerates young Simplicissimus of charges of lechery and adultery, Michael's decision to keep a coin, the disappearance of which led to young Simplicissimus' dismissal from the monastery, actually makes it impossible for the young man ever to prove his innocence in this regard.

Many of Michael's actions in the third section of the novel show clearly that he has not grasped the full meaning of old Simplicissimus' 
motto, that he recognizes only in others the truth of it. In the fourth and last section of the narrative (Chapters 17-20), however, Michael slowly begins to understand how his own perceptions are deceiving him. He witnesses a scene in which a young peasant lad rebuffs a girl who suggests that they go into the bushes together where no one can see them. The lad points out that God, who sees all, will assuredly see them. And Michael, upon reflection, realizes the truth of this assertion, and upon examining his own actions, invisible to mankind but all too visible to God, he comes to the realization that a thief is a thief, whether he steals from a Christian or a Jew. Michael abandons his plans and hastens homeward. A further important insight comes when he recognizes that in the case of the bribed mayor's wife he cannot possibly determine which party is guilty and deserving of punishment, and he comes to understand that he has not been ordained to pass judgment on others-only God has that right.

Even though Michael is now resolved to lead a God-fearing Christian life, he must sin yet again, and more grievously, before he can take the final steps of his inner journey. He seduces an innocent maiden befuddled by wine and sleep. The full import of this deed becomes completely clear to him when he stops a shepherd from committing a "sin which cries to heaven," for Michael dimly perceives that he himself has violated the innocence of one whom he, by rights, should have protected from harm and that he has thus done what the shepherd was about to do. And as he examines his deeds and misdeeds more and more closely, he comes to see his own condition in its true light and to become aware of his "vacuousness," "stupid ignorance, and trifling capabilities." This awareness of his insignificance makes possible the humility and contrition which are necessary if he is to be forgiven his past transgressions. Michael is now prepared to cast away the bird's nest, to renounce all further attempts to judge, 
punish, and reward, and henceforth to rely solely on God's goodness and mercy.

Michael's inner journey, like that of the world in the illustration to his tale, moves first in one direction and then in another. In the first section of the novel he is unaware of a goal for the "inner man," but in the second section he moves persistently toward increased insight. However, the realization that "perception deceives" prompts him to strike out in the wrong direction again. Insensitive to the need to examine himself in order to become aware of how his perception is deceiving him, he sets out to play God. Only in the fourth section of the novel, beginning with the comprehension of God's omnipresence, does Michael once more move toward the ultimate goal of his inner journey. With the achievement of a clear picture of himself, of his true condition, and of the potentialities which lie before him, Michael brings to an end both his inner and outer journeys.

\section{Techniques}

In The Wondrous Bird's Nest Grimmelshausen employs a number of narrative techniques and devices, some familiar from earlier novels and some now evident for the first time, in order to structure his work, to portray Michael's character, and to develop the central themes of the novel. Perhaps the most obvious of these is the repeated instrusion of the invisible narrator into the situations which he encounters. Sometimes he betrays his presence by some noise he makes, by shuffling his feet or by laughing out loud; sometimes it is a physical action he performs, all too frequently a violent one; and on three occasions he speaks to others. These intrusions by an invisible man invariably create in the visible world consternation, bafflement, 
and even fear and terror. They also compel Michael to become aware of how inadequate human faculties and judgments are.

Another technique which Grimmelshausen uses with great skill is the creation of contrasting and comparable episodes. The opulence of the mansion is contrasted with the squalor of the cottage, the perfectly innocent relationship between young Simplicissimus and the innkeeper's wife which is presumed to be lecherous, with the actual premeditated adultery of the cavalier and the cobbler's wife, to mention only two examples. Comparable actions and episodes also reflect on each other in an ironic but meaningful way. Michael, after stealing wine from a cellar, is thrown down the cellar stairs by invisible spirits, and later the invisible Michael hurls two thieves down a flight of stairs. In his wanderings Michael attends two wedding feasts. After the first, he is present when a peasant boy and girl lie together, and after the second, he himself seduces a maiden. Another striking example of Michael's performing an action which he has previously observed as a passive bystander concerns the realization of God's omnipresence. Michael hears a peasant lad point this out to a girl who wished to sin; later Michael, referring the reader specifically to this episode, points out the same thing to the shepherd who is about to sin. Perhaps the most interesting episodes which reflect on each other are the three in which insects play a significant part. After chastizing the blasphemous Calvinist Michael muses that God "generally punishes His most powerful and most obstinate enemies with the most miserable and most insignificant insecta." Later Michael himself is plagued by lice. And in the last stage of his journey, after he has been attacked by a swarm of honeybees, he reflects that "God the Almighty is able to employ even the least of insecta to chastize his wayward children." 
Grimmelshausen also takes care to choose Biblical allusions which will reflect meaningfully on the action described. The explicit references to the rich man and Lazarus indicate clearly Michael's view of the probable fate of the wealthy family and the poor cottagers at the Last Judgment. Michael later refers again to the same story from the Bible when he ponders the mayor's wife and the bribe, but here the emphasis is on the fact that it is the Bible to which mankind should turn for guidance rather than to misguided and sinful mortals. Michael's advice to the shepherd to "show thyself to the priest" makes much the same point by bringing to mind Jesus' words to the leper in Mark 8:4. Perhaps the most forceful example of the use of Biblical allusions is found in the crucial scene in which Michael finally comes to grips with his own sin and begins to feel remorse. In the words which Michael addresses to himself, Grimmelshausen has included a number of words and phrases from Psalm 51, which David sang after Nathan had rebuked him for having sinned with Bathsheba (II Samuel 11-12). In this way Grimmelshausen is able to imply that Michael's act of lust is comparable to David's, as is the action which Michael must take to attain God's forgiveness and mercy.

Grimmelshausen makes particularly skillful use of rationalizations to show Michael's progress toward self-awareness. Throughout the first three sections of the novel Michael is forever rationalizing his sinful behavior. He assures himself that robbing a usurer, and later a Jew, is not really a violation of God's commandment, that taking food and drink from the wealthy is not really wrong because they have so much of it to spare, that keeping coins that were thrown to musicians is perfectly all right because the money had been thrown away. He tells himself that he has every right to take some wine at the feast following the sale of the cow because he was a witness to the transaction, and he reasons that he can eat and drink his fill at the wedding feast and church fair because the hosts are urging all 
the guests to do so, and he is a guest. Even after he has realized that theft is theft, no matter who the victim may be, he persuades himself that it is better to take what he needs than "to become a suicide by starvation, against the will of God, against Nature and the laws of the world." Only after he has fully recognized and admitted his own sinfulness does he not only reject such rationalizations but realize that "this manner of excusing sin is itself a sin."

\section{Theme and Symbol}

In The Wondrous Bird's Nest Grimmelshausen treats several of his favorite themes. One is the "topsy-turvy world," which results from man's unreasonable insistence on gratifying his own desires instead of doing the will of God. Wherever Michael looks, he sees people producing disorder and grief by doing the opposite of what they ought to do. He fully realizes how perverse mankind is when he hears the little songbird enjoining the world to praise God, and when he contemplates the ant colony in which each member cooperates fully with the others in quest of a common goal. Old Simplicissimus' motto "Perception deceives" is a second theme which pervades The Wondrous Bird's Nest. Michael sees the truth of this maxim demonstrated in the actions and reactions of others, but he resists at first looking into his own soul and examining his own motives. Instead, he decides to lend God a helping hand, and in so doing he illuminates a third theme: the difference between man's justice and God's. In his attempts to reward and punish as he deems best, Michael is much like the tailor in the Grimm fairy tale who sits on God's throne during the Lord's absence and metes out justice in such fashion that the punishment is never commensurate with the crime, and completely unlike God's judgment would have been. The contrast is nowhere more vivid than in the scenes in which Michael and, later, the 
thieves are pushed down the stairs. Michael's fall, which can be seen as God's warning to him to leave off his sinful ways, leaves him battered and bruised, but otherwise unhurt; but when Michael pushes one of the thieves down the stairs, the thief breaks his leg and his back, and ultimately loses his life. Whenever Michael punishes what he considers a sin, more often than not blood flows and bones are broken; but God's punishments, where Michael is concerned, are far gentler, and each time he is punished, as in the case of the bee stings, a remedy is provided to ease the pain of his chastizement.

The central and most significant symbol of the novel (and of its sequel) is, of course, the wondrous bird's nest, and there are many ambiguities attending it. In bestowing invisibility on its bearer, thereby permitting him to see all, it bestows a capability which is the prerogative of God alone. Its origin, too, is at best ambiguous. Michael receives it from the hand of a dying miscreant, the Hopalongian hurdy-gurdy girl, and as he watches its next owner receive it from the hand of a sorcerer, or at least one versed in black magic, he also sees that this event is attended by a great pack of wolves, which are manifestations of the forces of evil. But does this indeed mean, as some critics have asserted, that the bird's nest is itself evil in origin and nature, an instrument of the devil? After all, Michael, while invisible outwardly, becomes visible inwardly not only to the reader but indeed to himself, and by being forced to regard his innermost self, after he has seen and judged others in their intimate hidden dealings, he is also compelled to examine and judge his own character and actions. The bird's nest is thus the means by which Michael is able to fulfill the most important command which the eremite imparted to Simplicissimus when he was a small boy and which is the central lesson for all of Grimmelshausen's characters, whether they grasp and pay heed to it or not: nosce te ipsum, "know thyself." Recognition that the world is topsy-turvy, that man is deceived by 
his perception of the world and of himself, and that it is the right of God, not man, to judge and punish is beneficial only if this recognition leads one to know oneself, for such self-knowledge, in Grimmelshausen's view, is the only way to achieve the genuine humility and contrition which are prerequisite to the truly Christian life. The bird's nest, it seems, is intrinsically neither good nor evil; rather, it is, like virtually everything else which falls into man's possession, a force for either good or evil, depending upon how its owner uses it. The very power which brings the hurdy-gurdy girl to her demise and damnation leads Michael to know himself and to resolve to live the sort of life in this world which can lead to salvation in the next.

Finally, the bird's nest is the symbol for the method used by the satirist himself. The author states at the end that his purpose in writing "this little book" was not only to please the reader and give him an opportunity to laugh at the folly of others, but also to cause him, if he feels that he himself has been depicted, to remain silent and "mend his ways, but also to pray God not only that He not allow you to fall, but also that He rescue your brother." 



\title{
Foreign Words and Phrases used in the Text
}

\author{
accommode: furnished \\ dicentes: words, statements, \\ utterances \\ actuarius: court clerk \\ discipules: pupils \\ agnus dei: Lamb of God \\ (medallion) \\ disputatio (ionibus): disputation(s) \\ annoncement: announcement \\ estime: esteem \\ annotationibus: annotations \\ exemplaria: copies (of books or \\ manuscripts) \\ aqua: water \\ ex officio: by virtue of one's office \\ attendre: wait \\ extraordinaire: extraordinary \\ baseylemons (baiser les mains): \\ compliments \\ gallant homme: cavalier, gallant \\ basilisci: basilisks \\ histori: story, tale \\ cloaca: cesspit, open cesspool \\ horas: prayers \\ comoedia: comedy \\ insecta: insects \\ compagnie: company \\ in specie: in coin \\ contentament: satisfaction, \\ contentment \\ in summa: to sum up \\ contre-marche: countermarch \\ in summa summarum: to sum up \\ once and for all \\ convivium: meal, repast \\ judicium, judicio: judgment
}




\begin{tabular}{l|l}
\hline laicus: lay brother & $\begin{array}{l}\text { praeludium Veneris: amorous } \\
\text { foreplay }\end{array}$ \\
\hline mamselle: young lady & refugium: refuge \\
\hline materialia: materials, things & rencontre: battle, encounter \\
\hline medicus, medicii: doctor(s) & salva guardia: guard duty \\
\hline mon Dieu: my God! & satyrus: satyr \\
\hline monsieur: Mr., gentleman & signor capitano: captain \\
\hline mouchoir: handkerchief & specialiter: especially \\
\hline prombre: number & studiosi: students (at a university) \\
\hline praelegatum: pre-legacy & viaticum: money to help defray \\
\hline partarius: notary & travel expenses \\
\hline
\end{tabular}




\title{
The Wondrous Bird's Nest of the HOPALONGIAN HURDY-GURDY GIRL
}

\author{
full of adventurous but instructive stories, \\ told in the Simplician manner \\ very useful and amusing to read
}

Prepared by

Michael Rechulin von Sehmsdorff

\author{
Monpelgart \\ Printed by Johann Fillion \\ toward the end of the year
}

1672 


\section{THE BALLAD OF THE WONDROUS BIRD'S NEST}

My bird's nest lets me see the crooked path, Which this, our world is e'er wont to pursue. The child can't see it with the strongest glass, For masque upon masque is all he has in view. I'll show you that we all are blind, and why, And whether you pay heed or no, I'll say: Beware, ye errant mortals, harm is nigh! Desist, lest ye from God's straight path should stray! 


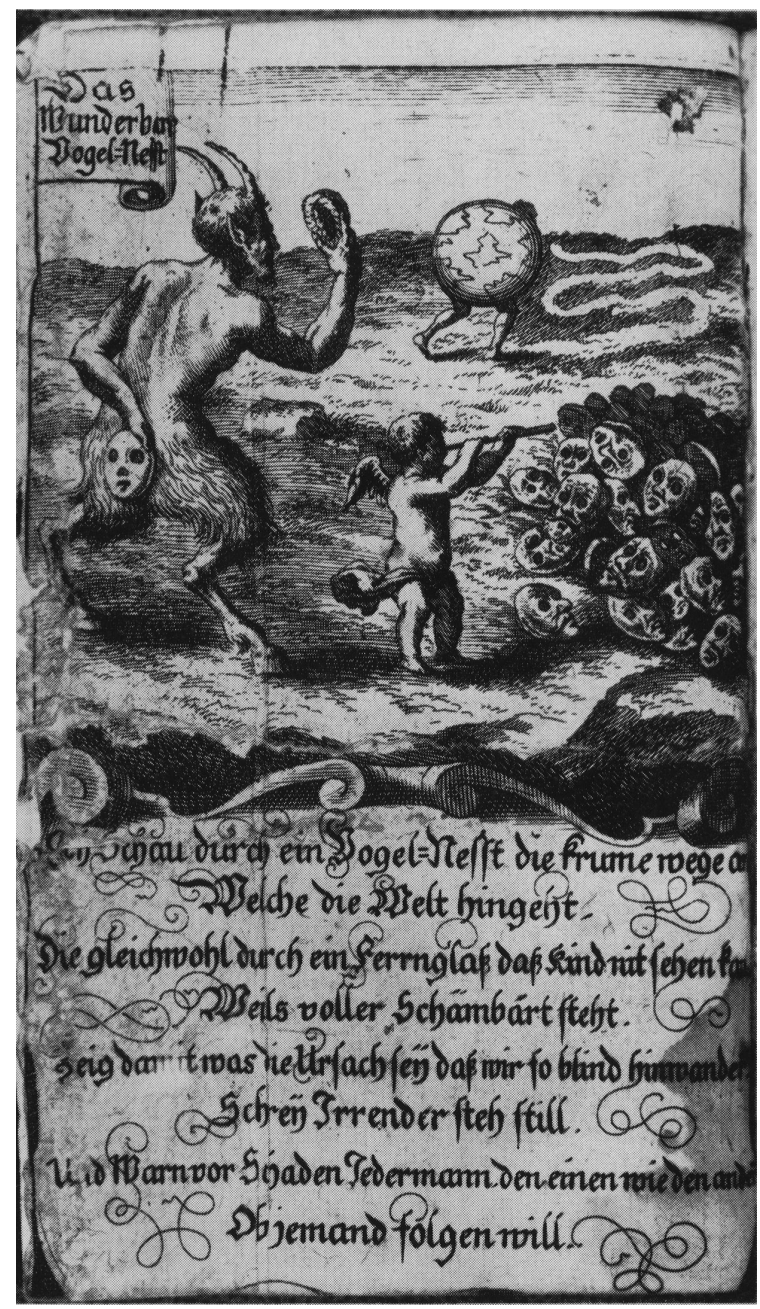

[frontispiece illustration of editio princeps; the German poem under the illustration is the ballad of the wondrous bird's nest] 



\section{chapter one}

In his life history, heedless Hopalong tells in what manner his hurdy-gurdy girl plucked from a tree this bird's nest about which I shall now undertake to speak, how she thereby became invisible, played all sorts of waggish pranks, and finally was deprived of life and limb; item, how at her demise the man who bent down to pick up a handkerchief she was dropping when breathing her last disappeared body and soul, hide and hair, clothes and all, so that since then no one has found out whither he has flown or fled. ${ }^{1}$

Now, dear reader, this fellow who disappeared was none other than myself, and in the handkerchief was the aforementioned bird's nest, which I caught as it was falling in hope of snatching whatever money or the like might be in it. But had I not caught it in midair but let it fall to earth, it would never have come into my possession, since in that case I should have been able to see neither the handkerchief nor the nest itself. But when I had it and now remarked from the actions and words of my comrades, the other halberdiers who together with me had been dispatched to capture the ghost or sorceress or accursed water fairy, that no one was able to see me, I should nevermore have exchanged this slight and small tree-crook nest with the King of England for all his kingdoms and provinces, for I was already making far loftier plans than Gyges did with his ring when he betook himself to the court of the King of Lydia. ${ }^{2}$

I no longer worried about food or drink or how I should henceforth clothe myself, or where I might safely rest and sleep; rather I pictured to myself such a great heap of lordly delights which I 
thought to obtain through the power and effect of this little nest that I was amazed at my good fortune and horrified at the power I now possessed, despite the fact that I had seen with my own eyes the wretched passing away and miserable end of the life of the woman who had possessed this nest before me and had used it in the way I was of a mind to do.

I paid little heed to the fact that the man who wrote the old chapbook about Fortunato, his purse, and his wishing cap 3 had wished to say, depict, and do nothing more than to demonstrate to the whole world that such wondrous things as these, which arouse impertinent desires without completely satisfying them and fill our minds with vain dreams but by no means truly afford them contentment, in the end bring nothing but misfortune with them. And it makes no difference whether such rare, uncommon, extraordinaire strokes of good fortune (as people like to call them) have their origin and their effects from the superabundant and yet still hidden treasures and secrets of nature, or that they come into our hands from Old Iniquity himself, the despoiler and archfoe of the human race; as we indeed know from experience that many people use mandrakes, 4 thieves' thumbs, ${ }^{5}$ and the like instead of a lucky purse like Fortunato's, and instead of a wishing cap use billy goats or indeed the devil himself to carry them from one place to another as they may desire. But all this I shall now put aside so that I may speak of my bird's nest alone with all the less confusion, and may tell how possession of it profited me, even though when I first came by it I too did not consider whether it might bring me advantage or harm.

Now after I had assured myself that no one could see me, I remained with the men with whom I had come, in order to finish what we had set out to do. I also went along to the inn where they were served and given a breakfast by the representative of the gentleman whose beloved was the owner of the clothes and jewels which the 
dead woman had been wearing. There I heard their wonderment at my disappearance and their various opinions and speculations about whither I might have gone; from which I learned that bewonderment is born of ignorance and that people make mountains out of molehills before they know that many a mountain gives birth to naught but a mouse. 6

I had as much of an appetite for food and drink as did my comrades, and therefore I snatched up a spoon without their noticing it and helped them devour the soup; and when we were finished with that, I also snared a piece of meat, which disappeared from the bowl before their very eyes, and after I had cut off my portion from it, it appeared in the bowl again, at which all present were horrified and were faced with the choice of whether they wished to eat any more of it or not. But from this I gathered that I must needs be more careful if I wished to keep my presence completely unnoticed anywhere. And then I became thirsty, and so that the tankard or glass from which I drank might not also disappear before the eyes of my already confounded comrades, which might have stupified them even more or per chance might have caused them to resolve to lay about them with their halberds in the room and execute me as they did the woman mentioned at the beginning of this chapter, I took a hearty draught from the innkeeper's large wine pitcher, which served me quite well, and grabbed from the basket standing there some white bread, with which I stuffed my pockets for future use, and then made ready to take my leave. But I was loath to open the door to the room myself, and therefore I let slip out gently and quietly some strong belly gasses, which as luck would have it I had in supply, and with which I so polluted the air that my comrades themselves threw the door wide open and chased out all the dogs, whom they blamed for the stench and with whom I walked outside in order to seek a better fortune for myself in the world. 



\section{Chapter Two}

It was already afternoon when I was walking through a forest in which I saw standing under a tree not far from the road a nobleman together with his servant who had tethered their horses and were engaged in a serious conversation with one another. I sneaked up in order to hear what they might be negotiating about with one another. The servant was dusting off the squire's boots, but the squire was fluffing up his periwig and at the same time instructing the servant in what fashion he was to behave when they came to the manor together. "Yes, Jack," he said to him, "par dieu, much now depends on you, and you can do more than anyone else to help me get the mother's consent and the girl to boot; just be sure that you always make my fortune in every way ten times greater than it really is; for my expectant future mother-in-law is a very wealthy widow who has many gold pieces, and for that reason would not give me her daughter in marriage if she knew the least thing about my impoverished state.

"And one more thing, damme! If perchance I should get drunk at night, so that I yowl and scream in my sleep as is my wont, and they hear me and ask you about it, then answer that I was doubtless dreaming that I was hunting in my forests, of which I have a great many, and that this is wont to happen to me at times when I have been on the hunt for several days in a row. Let me take care of the rest. I'll set things right with the chambermaid with a sovereign or two. Just be careful in everything you say not to let the cat out of the bag; if all goes well, I'll give you as a bridegroom's present the striped 
coat I had made but two years ago, so that at the wedding you may appear and shine like one of noble birth.”

He gave him many other instructions, and the servant promised to do his very best, all the while grooming his squire, on whom I, for my part, planned to play a trick, in which in fact I succeeded exceedingly well; for as he was powdering his periwig, I untethered his horse without his noticing it, mounted it, and rode off toward the manor where the squire was of a mind to go a-wooing1 for at the same time I wished to test whether the horse as well as myself, when I sat on it, would be invisible. But the squire straightway screamed: "Ods bodikins, Jack! My horse is loose, go catch it." The servant tried to approach the horse, but I fooled him by riding it hither and thither so that he was not able to catch it. This I did till the squire mounted the servant's horse in order to catch his own, whereupon I went full gallop toward the manor and let the pursuing squire bless his innocent horse as long as he liked with imprecations that it should break its neck, nor did I dismount till I was in the middle of the manor courtyard, for the gate happened to be open.

What was the good squire to do now? He was simply obliged to follow, although he had neither hat, coat, nor sword on or around him. But what put the seal on this letter, which confirmed his shame, or rather increased it, was that the good gentleman had in his haste not put on his periwig when he had mounted the servant's horse, and for that reason was obliged to appear with a freshly shorn head. I could hardly keep from laughing out loud and being heard when the rabble from the manor came running from all directions to see this fine spectacle. What ever will be the squire's excuse, I thought, for arriving on his servant's horse, and looking so strange in the bargain? But he was able to manage this much more skillfully than I had imagined, for he quickly mounted his own horse again and took the servant's by the lead, in order not to be seen by either mother 
or daughter, because he had no hat on to doff to them and offer the customary baseylemons. ${ }^{2}$

Thereupon he cleared out of the manor with all haste and back to his servant. He was hardly gone when the lady of the manor together with her daughter came up and asked what had happened, whereupon the servants told them everything which they had seen. The old lady shook her head at this, because she could make no sense of it, and ordered the drawbridge raised and the gate locked, for she said there might perchance be footpads about who were plotting heaven knows what manner of knavery, and in such situations one should be wary.

I took off my shoes, hung them on my belt, and began to sneak all around the house, in order to see whether I might find the old lady's gold pieces of which the squire had boasted; but I was beating my head against a stone wall, because I dared not break open either coffers or crates, much less open any doors, lest I be heard; and I could not get ahold of the keys either, since the old lady herself took care to carry them on her belt, which vexed me grievously. I imagined to myself that she must needs have scraped together much money, because otherwise everything in the house was so bare and frugal, as is wont to be the case in the homes of skinflints, whose hearts and souls are bent on hoarding up money.

The old lady herself, together with her daughter, was sitting in a room and spinning away as zealously and diligently as if they both had been hired to do so. The daughter's face and bearing made her appear much more beautiful and noble than did her clothes, for $\mathrm{Na}-$ ture had shown herself much more generous with her gifts than had jealous Fortune with hers. The maiden's eyes were still full of tears when I sneaked into the room. I know not why she had been crying, but her mother said to her: "There is simply no other way, my dear child! If we are to be able to afford the life which our birth and 
station demand, it will be necessary that we keep together what little we have, and for food and clothing make shift with what our lands provide, and moreover scrimp and save from this and from what we earn with our own hands enough so that we may put some of it by, instead of my selling one silver goblet now and thereby breaking and spoiling our set of twelve. It will be only three more weeks till all our flax is spun; then I shall receive at least twelve sovereigns for the yarn. That, in turn, will get you a fine dress in the new fashion in which you need not be ashamed to be seen at Cousin Freddy's wedding."

During this her mother's speech, the good maiden shed a few more tears, which so moved me to pity that I should not have stolen a thing from the manor, even if I had found a thousand brand new ducats in specie there. Rather I should have preferred to hear more from the old lady, and she would have indeed liked to say more because she was off on her favorite subject, but a dirty stablerat interrupted her discourse by running in and saying: "Your Grace, to judge by the horses, that fellow who was at the manor a half hour ago is once more outside the gate. He is talking with the overseer, claims to be Your Grace's cousin, and desires to speak with Your Grace." Hereupon the old lady peeked through the glass bay window, turned around quickly, commanded the stableboy to be off, saying to him, the overseer should proceed to announce the gentleman to her; but to the maiden she said: "Oh Criminy, daughter! It is Sir Pnnlss!3 Quick! Away with the spinning wheels and spindles, and on with your bluemorn dress, ${ }^{4}$ straighten things up, perfume the rooms," etc.

She, for her part, threw on another skirt and put a robe around her shoulders, and before she was even finished, the overseer came in and said: "Your Grace, Sir Pnnlss is at the gate and desires to come in and to wait upon Your Grace." "Go and let him in," she answered, 
"but not too quickly, so that my daughter may also dress up a little." But before she knew it, the maiden was dressed and tressed, for which reason the old lady ran down into the courtyard, and with harsh words, so that the squire outside the gate might hear them, she gave the overseer a rude upbraiding for having kept the honorable cavalier waiting so long, but with her eyes she gave the overseer to understand that he should pay no heed to her words.

Thereupon he was let in and given a friendly welcome by the lady of the manor, to whom he in turn paid decorous compliments. She led him into a room, and I sneaked in with them as if I were one of them or must needs be present, simply to hear how the squire would put a good face on his first arrival at the manor; for the lady of the manor told him that a short time before a cavalier, but one without hat and sword, had been in her courtyard, who, to judge by the horses and the way her servants had otherwise described him to her, must needs have been himself; for that reason she was greatly desirous to hear what manner of adventure had brought him there. "'Twas indeed I," he answered, "but never in all my days, dear cousin, 5 did such a vexatious thing befall me as today; and this shall indeed be a warning to me, henceforth never to ride afield alone with only one servant. In yonder woods that scurvy dog suddenly fell off his horse, I know not whether because he fainted, or fell asleep, or drank too much yesterday. All at once, there he lay, as if he were dead, for which reason I myself was obliged to dismount to look to him; during this hasty leap from the saddle my hat and periwig got caught on the limb of the tree under which my servant fell into this condition. I found him with his eyes rolled up in his head and shook him till I brought him back to his senses again; but before he was quite able to realize where he was, my horse ran away, and if I wished to get it back, I needs must mount my servant's horse and catch mine myself, because my servant was of no use in this. That, most esteemed cousin, 
is why I came here and straightway rode off again, not only to look to my servant but also to my hat. If I knew for sure that the sluggard was sleeping in the saddle, I should whip him like a dancing bear."

"Alas, dear son," said the old lady, "tis perchance the beginning of the falling sickness. ${ }^{6}$ Now if this servant is faithful and therefore dear to you, I shall give him a physic so that in the future he'll be free of it, particularly if he use it before twenty-four hours have elapsed after the seizure." "Why," answered the squire, "should my dear cousin take such pains on his account? If it isn't this fellow, it'll be another one. I can get servants aplenty, even if I whipped them every day and chased them off, because they know that in my service food, drink, and clothing are good, and they're sure of their wages." "Not so, dear cousin!" said the old lady. "After all, they are human beings too, and it behooves us, when such illnesses befall them in our service, to aid them with counsel and succor." But this she did not only to prove her sincere feelings toward the servant, but also to demonstrate her daughter's cleverness to the monsieur.

And when she gave a little signal with a bell, the stableboy, who was not as dirty now, however, as the first time, but rather dressed in clean livery, entered and asked with a deep bow what Her Grace was pleased to command. The old lady answered: "Go tell your young mistress to bring the key to the medicine chest." But to the squire she said: "We must, for heaven's sake, make haste to take care of this fellow." Now while she was still talking about this, her daughter came in splendidly dressed in her bluemorn frock, which masquerade, on the part of both the stableboy and the young lady, put me in mind of people acting in a comoedia.

The mother (after Monsieur Wooer had made his compliments extravagantly enough to his beloved) straightway commanded her daughter to prepare Recipe No. 17 for the servant of her cousin, Sir Pnnlss, and to see to it that he take it, the sooner the better; in the 
meantime she would speak with the cook about what to prepare for the evening repast, and she thereupon took leave of monsieur with a courtly bow, with the request that he bide a short time with patience till she return, to which he responded with equal courtesy, answering: "In all things my most esteemed cousin has but to command her obedient servant."

As soon as she had turned her back he followed the daughter to the medicine chest, which was a large box filled with all manner of materialia, such as roots, juices, electuaries, herbs, powders, distillates, plasters, ointments, and such, all in tins, boxes, phials, little cloth bags, etc., so that I quite approved of it as a model of an excellent family medicine chest, if, of course, the containers actually had in them what the labels described. Here the enamored Sir Pnnlss renewed and repeated his earlier compliments and expressed clearly enough for what purpose he was there.

"Gallant and eminent lady," he said to her, "the fame of your incomparable beauty and virtue, which has spread through the whole land, has also resounded in my unworthy ears and made me your most devoted slave! And this high fame has also aroused in me such a burning desire to look upon your person with my own eyes that I had not a moment's peace, but needs must recognize that I must obediently wait upon your mother, my highly esteemed cousin, in order to see whether perchance I might have the good fortune to see you and to worship your angelic form; and since at this moment this longed-for good fortune is indeed mine, I cannot refrain from confessing to you unreservedly that I bestow upon you, the vanquisher of my heart, all my freedom, and now desire nothing more exalted than the great honor of tarrying in your most charming presence forevermore and through all eternity, and of proving by all manner of faithful service that I am your most devoted slave." 
He brought forth a great deal more nonsense of that sort, to which the maiden replied politely enough. But I thought to myself, the fellow is pretending to be the maiden's servant, whereas he is really seeking to become the master of her mother's ducats, if only she have enough of them. [I did] not wish to listen to his bombast any longer, but sneaked off after the old lady to hear what goodies she was having prepared for the evening, from which repast I thought to snatch my share. I arrived just as she was dictating to her quarter-cook (for she spent hardly four hours of her daily service in the kitchen, because she assuredly spent the rest of her time doing other work) and giving orders about which pigeons' necks she should wring, and which chickens and capons, along with a suckling pig, she should stick; already hanging there were a calf and a young kid which had been stripped of their hides, so that there was no need to pay any money to a butcher; and already soaking in water were a moldy old ham and a few dried-out sausages, which were to be served with the salad. The lady of the manor was going to fetch the pickled venison from the cellar herself, which warmed the cockles of my heart, but certainly not those of the old lady; for when I sneaked into the cellar with her to take a hearty drink, she, thinking herself alone, lamented with a great sigh about her troubles: "Oh Lord!" she said, "The devil take it." (fishing from a keg a piece of stinking venison, for the loss of which she grieved more than did prodigal Cleopatra for the loss of her invaluable pearl). ${ }^{7} \mathrm{Oh}$, that I must now once again waste as much on one meal as I otherwise use in a week. I needs must go hungry three or four days for a week if I am to make up for it by saving and skimping." She did some more grumbling, not all of which, however, I was able to understand, nor desired to hear, but rather I permitted her to go back up the stairs unhindered and to lock me in the cellar to quench my burning thirst. 
This I did all the more fully by drinking from my hat, since I lacked any suitable drinking vessel, and I found the wine slight in quantity, to be sure, but in strength and taste far more excellent to drink for free than is wont to be the case in inns where one must pay for it.

I was obliged to remain a prisoner there for a whole hour before the cook came to fetch the wine drippings to cook with. To be sure, she took a good draught of the best Jochem, 8 but was nevertheless so discreet as to fill and take up stairs with her a porcelain mug filled only with beer. With her I emerged from my imprisonment, because I was plagued by thirst no longer, and arrived just as mother and daughter were urging monsieur's servant with kind words, while his master was urging him with threats, to take the medicine which had been prepared, which he no more needed than a wagon needs a fifth wheel. I was obliged to bite my tongue to keep from laughing when I saw this arsebackward folly and what puking faces the poor ninny made till he had gulped down this unnecessary draught of medicine. 



\section{Chapter Three}

In the meanwhile the time for the evening repast approached; therefore the table was set and everything put on it which belonged on it. I went over to the table in order to hear what manner of merry discourses there might be, but there were nothing but compliments, puffery, and statements which were intended to show the great wealth of each party. Now because no place had been set for me and I was loath to take anything from the table, I got a smoked sausage by the tip-end and straightway dispatched it on its way to its billet till I might quarter a piece of ham along side it; but the ham was not only not sliced, after the meal (when the servant had pulled off his master's boots so that the latter might go to bed) it was locked up in a box, and as much of a to-do was made about the missing sausage, which they thought the dog must have eaten, as if not only Candia 1 but Venice herself, had been devastated by the neglect of the careless servants and had fallen into the hands of the Turks.

Now after the squire had gone off to bed sober (for there had been no one there to get him good and drunk in the good old German way), they then tried to loosen the tongue of his servant, who after taking the medicine, so the old lady claimed, durst not become tipsy on beer, and must not drink any wine at all, lest that make his condition even worse. Nevertheless, he did not fail to boast loud and long, in accordance with his instructions, about his master's great riches, to which both the old lady and the young one listened with pleasure and reverence; and indeed, he put a better face on the matter than I should have thought the lout would be able to. But when 
his squire began to scream and yowl in his sleep, he missed the mark by a mile, I know not whether because he had forgotten his squire's good instructions, or because he had simply grown sick and tired of lying. When the lady of the manor then asked him what the screams signified, he bluntly answered: "When my master begins to scream that way, he is commonly wont, shortly thereafter, to shit in his bed (if you'll pardon me saying so)," whereupon the maiden became so consternated that her face turned the color of a glowing coal.

The old lady straightway took note of this and worried that because of this her daughter might perchance become disinclined to, and go back on, the impending advantageous marriage, and for that reason she gave her aforementioned daughter a little smile and said: "You must not be s. 'Tis really a good thing that he gives warning before he shoots, because after all, that way one can still get out of his line of fire, or even retreat from the bed till the salvo is over. You must not be so frightened at this." "Yes, but Mother," answered the maiden, "I am not concerned about what you think I am, but about the sheets. They are borrowed, more's the pity, and must be returned tomorrow."

At this the mother was more consternated than the daughter had been by the servant's annoncement, because he had heard that they had been obliged to borrow the sheets; therefore she wished to muddy the waters and remedy her daughter's gaffe, and she said to her: "Why, you lazy baggage! Why did you not tell me? I should have given you a pair from the chest." The good maiden, wishing to excuse herself, said: "Well, yes, if I had thought there were any in it," at which the squire's servant pricked up his ears, and I laughed so hard that all in the whole room heard me, and thereby I so horribly startled them that young and old, woman and maiden, and, in summa, everything with two legs ran out the door. I, for my part, was so angry at having so heedlessly forgotten myself that in my great 
ire I walked over and squeezed the wine tankard standing there so hard that not a single drop was left in it. After that I too sneaked off and wiggled into the hay in the stable, where I pondered on what I had seen and heard that day. I especially was most amazed that these people, who after all were of a mind to marry and to enter into such a close blood relationship with each other, were not loath to pull the wool over each other's eyes with such double-dealing falsehoods, lying fraudulence, and boastful pretensions. Oho! I thought. If they do this unto each other when they wish to establish an indissoluble friendship with each other, how will they treat those who have dealings with them and whom they do not deem worthy of their kinship? With such thoughts I passed a few hours, till I finally fell asleep.

The following morning my thirst drove me once more to the house, to see whether I might perchance quench it with a drink of vermouth, for in the cellar the day before I had seen that the lady of the manor, as any sensible house wife would, had a supply of such healthful medicated wines in various little kegs. And happily I was successful, for when the cook (who was also obliged to serve as keeper of the wine cellar and the keys) came to fetch something from the cellar for breakfast, I know not anymore what, I whisked down into the cellar with her, permitted her to lock me in, and after she had locked the door I assailed half a loin roast which had been on the table the night before and had not been consumed, either because of the stinginess of the mother or the restraint of her would-be future son-in-law. It tasted excellent, and I not only felt not a single pang of conscience that I made more bold than the gentry to attack such a tasty morsel, but also I goaded myself on to drink more than twice as much as I had a mind to, or my thirst warranted. But I was even more fortunate, in that the cook soon came back, not, to be sure, to let me out (for after all, she knew naught of me), but to fetch more victuals. At that moment I sneaked through the door, and the last thing I 
heard was the cook saying to the quite desecrated roast: "A plague on you! Who's been at you? Cats don't carry knives! Oh me, what will milady do?" But I did not worry myself a whit about that, nor about whether the marriage between the squire and the mamselle might come to pass or not, but rather I put on my shoes once more and wandered out of this temple, having in mind to betake myself to a large city where there were merchants and moneychangers, to see whether perchance the occasion might arise for me to share with one of them his excess monies.

I had walked for approximately two hours when I encountered not far off the road a company of beggars who had made a fire and were sitting round it cooking and frying food, truly merry lads. Outwardly, to be sure, they were miserable and pitiable to behold, but their cheerful laughter, their uninhibited demeanor, and untrammeled speech made me recognize that inwardly they were completely free spirits, which then, of course, drew me to them. I had been sitting with them for barely a quarter of an hour when they heard a coach full of travelers approaching. "On your way, Slyboots." they said to an old man. "Tis your turn now to demand tribute." And this Slyboots was not slothful either, but forthwith closed his eyes and had a young lad lead him with a cane to the road, where with a doleful and pitiable clamor he extorted a few coins from the travelers. When he came back to the compagnie it was the wish of all of them to buy a good honest measure of wine with what he had secured, because by the sound of the two-and-a-half-measure flask it was clear that it would not last another round for everyone in turn to take a full draught, particularly since a large pan of cooked eggs was there which pled for such a convoy. I observed especially how an ancient grandmother, who to my mind had learned to pursue this profession in her youth, prepared a mixture of flour, eggwhite, brains, blood, and verdigris and made from it for a lad a scab, 2 after she had first 
washed off the old one, right down to his healthy skin, and had skillfully shorn his scalp anew. "There, my child," she said, "now you truly have such a pretty mange that no one could paint one which looked more natural! Just pay heed that you not make any mistakes when you're saying your prayers; whenever you notice that people are not Catholic, for heaven's sake leave out the Ave Maria, and don't beg for alms for the sake of Our Dear Lady either, but instead add to the Lord's Prayer "and Thine is the kingdom and the power and the glory"; but if you don't know whether a village is Lutheran or Catholic or Calvinist and also durst not ask what it is, then pay heed to the statues and saints' shrines and crucifixes by the wayside; if they have fresh flowers or are well kept, then make so bold as to pray like a Catholic; if not, pray like a Lutheran; and if you know full well that you are in a Calvinist village, then say 'Forgive us our debts, as we forgive our debtors' and not 'Forgive us our trespasses, etc.,'3 as was the custom since ages past, because people gladly give alms to those of their own faith, and even large coins too, whereas many a person will not even cast a glance at anyone of another confession, even if he were ten times more in need of alms than someone of his own faith. Just take care that you be cautious and diligent, and you'll fare better than if you were tending horses for some peasant, or were even to secure and in time possess a large pile of goods of your own, because these turn the otherwise free spirits of their owners into martyrs and tormented slaves, and their bodies into the bonded thralls of somebody under whose jurisdiction their bodies may hap to be. Whereas in our own order you possess and richly enjoy noble freedom, and with it, under the mantle of poverty and from the wealth of others who are compassionate, everything which you need to maintain your life of idleness.

If some niggardly dog does not wish to give you anything, then knock on another door; if a country is spoilt by war, hard times, or 
mortal epidemics and thus not conducive to your prof-eat-ion, ${ }^{4}$ then go to another, and let those who have given up their hearts to hearth and home, to their fine and well-situated properties, stay home and suffer destruction, devastation, and death."

The old woman imparted to this lad a host of other such fine lessons and instructions, and I do not believe a hunter would devote greater effort to training a young spaniel, or a signor capitano to drilling his tirones; ${ }^{5}$ and the little boy was of the sort who willingly learn what they are taught, and after all, who would not, if they're preaching to you naught but sloth, freedom, and indolence?

Another one was telling old Slyboots how formerly he had played a mute for four years, which manner of begging had profited him so well that he had got together quite a bit of money, which, however, was pilfered from him by the young wife whom he had had at that time and on whom he had doubtless been too easy; whereupon he of necessity had been obliged to take up speaking again in order to inquire after his wife, whom in fact he had come upon with a young tinsmith but had dared not address, firstly because she had not been his lawfully wedded wife, and then too so that she might not betray that he was pretending to be a mute. "You cannot believe, nor can it be put into words," he went on, "how it vexed me that I was obliged to throttle and bottle up the rage within me; and this was the greatest cross and burden I've been obliged to bear since I left off working like a horse at the jackass job of a day laborer and, by taking up the beggar's bag and cane, entered into the priceless freedom of our lordly life! But straightway thereafter I got me another doughty young wench, a basket weaver's and tinker's daughter, who not only was able to learn our trade better than my first wife, but also presented me with at least one child every year, or two every other year, by means of which children I took in many alms; on top of this, she devised a clever trick to make money when it was otherwise hard 
to come by, namely, in the winter time when we were outside a village she stripped herself completely naked in the bitterest cold and left clothes and children behind with me; in this condition she often received in one day one, two, or three florins' worth of clothing, depending on whether she came upon compassionate womenfolk who felt shame for her, which set right well with me and wangled us many a bowl of hearty broth." 



\section{Chapter Four}

While the beggars were telling each other their capers, two Capuchi monks came by, and the beggars did not even do them the honor of standing up and begging alms of them, I assume indeed because they knew that the monks have naught but agnus dei1 to give away, of which they desired none. One was an old pater and the other a young cleric. I left the beggars, and because the monks were going my way marched along with them to hear what manner of discourse they might have with one another on the way; but I heard as much as if I had been walking with two mutes, except that before entering a village they sat down together and said their horas ${ }^{2}$ together.

In the meantime I pondered on these dissolute beggars, vagabonds, and useless runagates with whom our German lands are flooded, as it were. I was already considering proposals about how I wished to proceed with them, to employ their order for the good of the fatherland, and what I should propose in regard to them at the Imperial Diet, should I ever become a prince of the realm. I selected the healthy ones among them to be soldiers, in order to protect the fatherland and make war on the Turks, and in this country of mine (which in my mind I possessed) I was already building penitentiaries and workshops in which I planned to make such arrangements for the rest of them that both the deaf and the mute, the blind and the halt, would be able to work in them and not only earn their daily bread for themselves, but also provide food for the rest of the miserable cripples, and, moreover, would be able indeed to save and turn over every year a considerable surplus to the common weal; whereby 
this riffraff would be disbanded, God Himself no longer angered by their rude life, the countryman no longer molested by such large hordes of them, and an order established such as is pleasing to God and useful to mankind.

But in the midst of these thoughts I did not think at all that I myself was a worse footpad than these beggars, since at the time I was planning, with the aid of the bird's nest, invisibly to rob honest folk and enrich myself. But had I thought of that, I, like that woman who was presented with proof of her having sinned just as she herself was about to punish a subordinate for the same transgression should doubtless have pled and said: "Alas, God have mercy upon us, we are all prey to human frailty!"3

But enough of this! When the Capuchins had finished with their prayers, my schemes were also at an end; for that reason I went along with them into the village to see what manner of convivium their pious prayers might produce, but they did not turn in at the inn, but instead sat down under the linden tree which stood on the square between the church, the parsonage, and the inn, in order to enjoy the shade and to rest their bones, fatigued by the great summer heat. I likewise took a rest, and scarcely had I sat down when out of the parsonage came the parson's wife, a truly beautiful young woman who was, however, as I later remarked, as simpleminded as she was pretty. She bade the two Capuchins a very friendly welcome, with the added request that they come into the house with her and have a drink and whatever the kitchen had to offer; but the Capuchins flatly rejected her sweet offer, I know not whether because they perchance feared that through this woman the devil might be setting a trap for their chastity; she, for her part, was not greatly pleased by this answer and said: "Good Lord! How peculiar you are! Just come right in! I am the parson's wife and was wed to my husband but four weeks ago. Do come in, for if we clergymen do each other no honor, then who else 
will?" But the Capuchins did not wish to, but instead went on their way, albeit that I could tell by looking at them and by my own condition that a good drink would not have done them any harm. But on the other hand I also thought: Be thankful to God, my dear young woman, that the Capuchins did not follow you into the house, for if your husband had come in, he would have thanked you no differently than if in his absence you had invited these beggar monks, whom he detests anyway, into the house for quite a different purpose, even though neither you nor they had anything evil in mind. Besides, I was irked at the Capuchins for not going into the parsonage, because I was of a mind to quench my thirst there along with them, for which reason, since I was in need of a drink, I went to the inn to see whether one might not be forthcoming there.

Sitting there was a whole table full of peasants, all of whom were of the Calvinist religion, to which faith, in fact, the whole village adhered; and they were most piously singing several songs and psalms from Ambrosius Praisewater's hymnal ${ }^{4}$ while drinking their wine unadulterated by water, which mixture I liked much better than pouring real water into the wine as the Italians and the Spanish do. Straightway thereafter two Catholic passagieres also came in who partook of a bite to eat there and whom the peasants recognized when they crossed themselves, because of which the peasants straightway changed their song and to mock them sang the Ave Maria gratia plena. When the Catholics, however, paid no heed to this, they began to tell all manner of bawdy tales which supposedly had happened in the Catholic church because the priests had not instructed their parishioners more carefully.

One told a story from Tales Merry and Grave: 5 "Once when a little girl was saying confession, the priest asked her if she ever peed in the bed, and when the child answered 'No!' he said, 'Well, don't ever do it, for I eat little children who pee in the bed.' Whereupon the little 
girl said: 'No sir, I don't pee in it, but I have a little brother at home who shits in the bed. Eat him!'” And thereupon they all began to laugh as if they were daft and deranged, all the while looking around to see whether the Catholics would make some rejoinder to it or grow angry at it; but these two acted as if they had not heard or understood anything, but rather when the laughter died down one told the other the following: "In our neighborhood recently a Protestant person was about to baptize a child, and when he came to the place where he asked the godfather: 'Dost thou renounce the devil? Repeat after me: I do renounce him.' The godfather then answered: 'Dost thou renounce the devil? Repeat after me: I do renounce him.' The parson shook his head and said: 'Methinks thou art a fool!' And the godfather straightway answered: 'Methinks thou art a fool!' Whereupon the parson grew angry and said: 'Get this witless fool out of my church!' The godfather thought he was supposed to continue to repeat after him and likewise said: 'Get this witless fool out of my church!' Now if the child was ever to be baptized they must needs get a more sensible person to take the godfather's place."

Straightway thereafter one of the Calvinists told how a priest had asked a young girl in confession whether she liked boys, to which she answered: "Sir, heretofore the boys and I have never paid much heed to each other, but on the next holy day I'm getting a new frock, and then the humping will really begin!"

"In Switzerland," another said, "where the most pious mountain folk come to church at best but once a year, at Eastertime, an eightyyear-old father sent his twenty-five-year-old son to church for the first time, and when he came back home he examined him about what he had seen and heard. Then the son told how one fellow had gone on and on about another one, about how he had been betrayed and bartered, seized, bound, dragged off, beaten, and finally even crucified. 'Yes, father,' he said, 'they treated him so badly that I truly 
pitied him. ' Lord! Lord!' replied the old man. 'Hasn't that affair been settled yet? It's been a good twenty years since I was last in church, and even back then they were arguing that case. I just wonder what our magistrates are doing, that they don't settle it for once and for all!"'6

"That's not surprising," one of the Catholics then said, "for we know from Dr. Schupp's Friend in Need that once upon a time a German nobleman who was being examined from the catechism by his parson to see what he knew about Christianity bluntly answered that he was a fool and that he thought that the parson was one tooinstead of saying that he was a Christian and believed in Christ."7

But so that there would be no more talk of this, another Calvinist said: "After a Swiss had confessed to a Capuchin and had received absolution, he wished to give him a farthing for hearing his confession, but when the pater refused to accept the money he said: 'Go on and take it, dear old father, you should not be made a fool of for naught!'” And thereupon they all again broke out in laughter as before; the Catholics joined in the laughter and said: "That must surely have been an ill-bred oaf!" But then they countered with this story: "When a parson was giving a funeral sermon for a deceased shoemaker and came to the place where he was also supposed to praise the dead man, he said: 'Dearly beloved, I should also extol our departed brother for his godlessness and other virtues; but in order that I may earn the sovereign which is owed me for the funeral sermon, I hereby say to his everlasting praise that bad as he was otherwise, he did have a beautiful red beard, just like our sainted apostle Judas Iscariot," etc. ${ }^{8}$

This thrust the Calvinists parried with another when one of their party said: "And what about you Catholics and your confessions anyway? Everyone knows about the village of Schttrwlt, 9 of whose citizens they say to this very day that even the most pious amongst them 
once stole an axe. This taunting insult goes back to an incident which took place during the time which you deem the holiest of all and during which you seek to rid yourselves of your sins through confession and penance. For after one of them there, during Shrovetide, had feigned piety and had received absolution, he went out of the church door and when he went to pick up his cane leaning by the church door he picked up instead a brand-new axe which was standing next to the cane and took it with him, saying: 'Ah! The Lord provides! This will go on next year's list of sins!"”

"I believe," said another Calvinist, "that telling one's sins specialiter in confession was merely invented and imposed by priests to keep the conscientious fearful and under pressure to contribute money; for who would not hold in high esteem a person to whom he must entrust his innermost secrets, and who would not aid this person with all his fortune, stuff his pockets and keep his belly fat in order to keep him in good humor and remain in his good graces? But others, like us in the pure reformed faith, take it to be just a joke, as did that woman who could not be absolved of her sins unless she told her husband that her last-born child had been sired not by him but by another. The woman, to be sure, did as she was commanded to do, but how did she do it? She waited till the child was crying, and in order to silence it she said to her husband: 'Peter, put a blanket over your head and frighten the child a bit so the little bastard will be quiet!' The husband did as he was bade, and when thus disguised he began to growl 'Boo! Boo! Boo!' his wife said to him: 'Go away, you nasty bogey-man! This is my child, not yours,' etc."10

Hereupon one of the Catholics answered: "That is the same old song sung by those who because of pride do not wish to confess their sins, or who because the devil has tricked them into false modesty do not wish to tell of their sins, thereby making a mockery of the humility of true penitents. Nor is it at all credible that confession derived 
from the avarice of our clerics, since they obtain enough from their prebends to meet all their needs, and they also need not provide for any heirs, for whose sake they would have cause to scrape together a great deal, as do your clergy.

"Not long ago a Protestant prince called together all the divines in his country to confer on something concerning the liturgy. They waited in the antechamber till someone came and said that the divines should enter; all obeyed save one, who remained outside; now when this one was missed, another was sent to call him, but he was loath to enter, saying that only divines had been commanded to enter, but he was not a di-vine but a di-aqua; ${ }^{11}$ now if the prince should call in the di-aquas, then he too would present himself. The messenger reported what the man outside had said, at which the prince and others thought that he might perchance be touched in the head and therefore sent two of his colleagues to him to see what was wrong with the fellow. They asked him how they were to take what he had said and what he had meant by acting so contrarily. He answered: 'They only asked for di-vines; now there is not one amongst you who does not receive as part of his yearly income at least a half a barrel of vinum. So you may well call yourselves di-vines. But I have nothing of that kind, but instead must needs moisten my lips with water, and therefore I must needs account myself one of the di-aquas. Why should I be together with you when I am not asked for, etc.' Through this merry prank the di-aqua brought it to pass that the prince had a half a barrel of wine bestowed yearly on him too, making a di-vine of him as well."

Telling this story, which was already sufficiently well known to them anyway, so embittered the Calvinists that they gnashed their teeth, and in order to mock the Catholics they all began to sing the Ave Maria again. The Catholics, however, did not grow angry at all about this, or at least acted as if it did not vex them in the least; and 
when the Calvinists paused a little, or simply had screamed themselves hoarse, one of the Catholics said: “That's fine, gentlemen. That's the way one should pay homage to the Mother of God. If you continue this way, there is good cause to hope that you'll soon become, if God so wills it, good Catholics yourselves." "What? Pay homage?" said the biggest man among the Calvinists. "What? Us soon become Catholics?" And with that the mad fool leaped up from behind the table and stood in the middle of the room with his arms akimbo and said: "You people must know that when we sing that song we are mocking you because you have let yourselves be persuaded to worship a diaper-washer." This vexed me not a little when I considered that the humility of the most glorious Holy Virgin, who for all our sakes gave birth to the Saviour of the World, deserved better than to be reviled by such a blockhead, especially since even the Turks do not let such blasphemies go unpunished. What? thought I. Are you to speak ill of the mother of Him of Whom you believe that He will save you from sin, death, devil, and hell? The two Catholics, however, with patient sighs put their pipes in their pockets, and were indeed not unwise to do so, for one could readily see from the looks on the faces of the Calvinists that they were itching to tan their hides if they had but uttered another word.

This moved me to pity, and when the above-mentioned fellow did not cease to speak contemptuously of the Virgin Mother, who is praised by all men as blessed in all eternity, world without end, I gave him such a solid clout on his insolent snout that it knocked out four of his teeth and he himself, the whole length of him, fell to the floor on his back. And no one should be surprised that this blow had such a strong effect, because in my home town they called me Mighty Mike, because I am able to hand out such boxes on the ears so mightily and masterfully. All present took fright at what had so wondrously befallen him, and deemed it divine retribution and 
a warning, simply because they were able neither to see me nor to know who had dealt him this blow. I myself, however, deemed it divine punishment for him, because God is wont to speak truth even through the mouths of sinners, and generally to punish his most powerful and most obstinate enemies with the most miserable and most insignificant insecta.

Now while both Calvinists and Catholics were sitting there completely dumbfounded, the fellow, who was bleeding like a stuck pig, picked himself up again and showed himself as quiet and docile as a lamb. On this occasion I thought that I should have made a fine praeceptor, since with one blow I had been able to produce such wellbehaved discipules; but if they had been able to see me, how those half-drunk peasants would have thrashed me and made me pay for my preceptoring.

In this moment of quiet, while everyone was gawking at the victim, I grabbed the peasants' tankards and guzzled them empty to the very bottom, because up to now I had still been suffering from thirst, because I had not been able to get at them as unnoticed as I wished to. The two strangers went their way, and I cleared out through the door with them. I know not what the peasants said, or what manner of miracle they made of it when they discovered that the wine had vanished from their tankards. 



\section{Chapter Five}

That same evening I went no further than to a tiny little village which had no inn and only about thirteen houses. There I turned in at the one which had the largest pile of manure in the courtyard, because on that account I took it to be the richest home in the village and therefore believed that I too should be able to best get my feed there that night, but I found myself deceived, for this farmer was a miserly wretch. He had no servants or hired hands, but instead lived with his now grown-up children, whom he fed a watery soup and a big panful of oatmeal, with which they were obliged to make do, but which nowadays not even hired men or maidservants would have put up with. So I was very nearly obliged to go hungry, for as long as they were eating their evening meal I sat sulking behind the stove and fed on my own impatience, since I could entertain no hope that anything worth eating might be lodged in my stomach that evening.

Straightway after the meal the two sons were sent to feed the horses, and the daughter to feed the kine. In the meantime the mother went off to gather together the market wares, namely, what she was of a mind to sell the following day at the nearest marketplace. These wares consisted of a dozen two- or three-pound heads of milk cheese, three score eggs, several cockerels, and about ten pounds of butter which she had divided into one-pound bricks. All this she neatly packed into a large basket, save the chickens, which had been put separately into a wicker cage. I should have been able to light the way for her while she was doing all this, because I sneaked after her everywhere she went and watched what she was doing, but that was 
not the reason I did this, but instead I laid hold of a piece of rotten cheese, together with a bit of butter, which, to make up for the long wait, I munched on with a piece of bread which I still had in my pocket. After this I went with her back out of the cellar to the room where her husband was sitting, his head in one hand propped on his elbow, and with the other hand picking his teeth as if this very evening they had been obliged to grind up steak and venison. But the good man had in mind something different than I imagined, for straightway thereafter he said: "Yes, wife, 'tis simply not right for us to give our Meg to Nicholas' boy Bobby Joe. Think about it yourself! We should then be obliged to straightway hire a maid; she would cost us at least twenty guilders a year, not counting her keep. And just think how much the wedding would cost us, what with the fiddlers, the bridal feast, the bridal gown, and clothes for us and for our two boys. And just think how much we should be obliged to give her for her dowry, not to mention the praelegatum, ${ }^{1}$ which we assuredly must needs hand over to her, thereby reducing our entire income by half. And anyway, these are such hard times, in which our crops and cattle will soon not be worth anything, so that we barely have enough left over to pay the manor taxes and the stewards their taxes and interest, and on top of all this, should we put on such a feast and thereby ruin ourselves completely?"

"What you say is true, my dear Jack," answered the wife, "but you must also remember that day and night come when it's time for them, whether you like it or not. That girl has long since reached the marriageable age, and to please you has rejected several proposals, and has put up with more in our house than any maidservant would, and has done her best, and this is a very good marriage for her too. Should you make so bold as to thwart this one too, as you did the others, then you'll be treading on thin ice, and Meg's guardians would see through your game and say you wish to stand in the 
way of your daughter's happiness just so you won't be obliged to part with her maternal inheritance. So be careful what you do, and do not make so bold as to try to prevent something if you see that you can no longer prevent it anyway."

"What!" the farmer then said. "Am I to have a child who won't obey me? She'll not have the fellow against my will, even if she were to have kittens about it! I'd like to see anyone who can force me to let her marry." Now when the farmer's wife saw that her husband was growing so mad, she said nothing more except: "As far as I'm concerned, you're the master, and smarter than I am, so do with your daughter as you wish."

Straightway thereafter the sons came in and their father commanded them to go to bed so that the next morning they might arise all the earlier; and then the daughter came in, and he commanded her to do likewise, but only after she had first washed the dishes in the kitchen. Now because the cheese which I had eaten for supper had given me a great thirst and there was no hope of quenching it with wine this time, I went out with her, and sticking my head into a bucket like a cow, I very stealthily took a large swig of water, which was something I had not tasted for a long time. Then I saw and heard how Meg, while washing the dishes, sighed and wept, without my being able to divine the cause thereof, which, however, I soon learned. For when she went to bed, I sneaked after her and lay down in a corner of her room on some black linen rags and old sacks, but because of the cheese, of which I had partaken too much late in the night, I was no more able to go to sleep than was Meg, who continued to lie there in her bed heaving heartfelt sighs. But after about an hour and a half had passed, someone knocked on the shutter. "Meg! Meg!" he called wery softly. "O sweetheart, wake up and let me in!" Meg got up and first made sure that it was really her Bobby Joe, and when she recognized him opened the shutter and said: "If you'll be good, I'll 
let you in, and I'll tell you something which is important to you and me." Thereupon Bobby Joe swore by all that's holy that he would do as she wished; Meg then let him in and informed him of everything which her father and stepmother had said to one another that evening about them, which conversation she herself had heard while standing outside the window and eavesdropping.

"Yes," she said, "they say that if you have a stepmother you'll get a stepfather too, but my stepmother means better by me than does my very own father! If she had her way, we should be able to get married right away. But if things go the way my father wishes, as long as he's alive I shan't be permitted to take a husband, even if I should be obliged to wait till I be accounted an old maid." Bobby Joe, for his part, consoled her and said that if that was the way things stood, she must needs think of herself first and of what was best for her. This much he knew: that her two guardians and his parents looked with favor on the marriage, and if she were willing to take him under these circumstances, he would not forsake her, in all eternity, but would see to it that they were united forthwith; in summa, he spoke such sweet words to her that Meg finally said yes, and so far as I could tell got his firm promise that he would marry her.

Hereupon I heard from the smacking noises that she was letting him kiss her, and shortly thereafter go a good bit further, for he sweettalked her out of her maidenhead, and upon repeating this pastime again and again he grew so wild that the bedstead complained of it and I myself grew quite ill from it. Toward daybreak, however, he left Meg weeping, albeit he swore with terrible oaths that he would be faithful to her and climbed back out the same window by which he had entered, promising to return the following night and to report what his parents and her guardians had said about their having taken each other. 
Now when Meg put on her clothes in the morning to go milk the cows, I sneaked along with her out of the room where she, to be sure, had spent a tender night, but I a hard one; for not to mention other nuisances, fleas in that room, rather than sleep or rest, had honored me with their attentions. I therefore left that unhappy village, and after walking about an hour came upon a merry little woods through which flowed a lovely little brook, by which I lay down under a tree with the intent to sleep a while. But scarcely had I dozed off when I heard something plop down close by me, which awakened me again. When I opened my eyes, look you, it was my farmer's wife, who had put down beside me the basket in which she had her market wares. I watched her as she unpacked one after another her butter and cheese and moistened the bricks of butter one by one in the little brook so that they would stay good and hard and fresh. And the cheeses were lying there in a separate pile, and over them she squatted like a broody hen over her eggs and moistened them as nicely with warm water as she had before wet the butter with cold water, so that I could not but think to myself: "May lightning singe your arse!" But I did not simply leave it at that, but put on my glove and grabbed a handful of stinging nettles which they give to crayfish ${ }^{2}$ and which, as luck would have it, were growing there. Thereupon, quickly and with all my might, I grasped the farmer's wife, still squatting there leaning forward and doing her business, around the waist and rubbed the nettles into her backside so that she flashed and bucked like a she-ass. She screamed, to be sure, as if she were being murdered, but I paid no mind to that, but instead so belabored her arse and thighs that she will surely remember her cheese-wetting for a little while. And I believe that I'd not have stopped belaboring her to this day, had I not recalled just then that the evening before I too had eaten of these cheeses, which caused me such revulsion that I must needs spew out everything I had inside me, whereby I nicely decorated the dress of 
the farmer's wife here and there; but I did manage to keep down my lungs, liver, and guts, with which organs I betook myself thence and left the farmer's wife to do and think whatever she wished.

May the most gracious, honorable, and virtuous reader forgive me for telling this story so crudely and coarsely. I should have been most willing to dress it up a bit, but I have not been able to find gentle words for such uncouth things. 


\section{chapter Six}

This cheese affair with the farmer's wife had driven all thought of sleep from me, and because I knew that this day the weekly market was being held in the next market town, I set out on my way to see whether I might once more in proper manner fill my stomach, which I had just now so disgustingly emptied. I arrived just at the time when the marketplace was becoming the most crowded, and the first article I acquired was a satchel, which I snitched from a leather-goods merchant who, after all, was offering them in order to get rid of them; for I thought to myself: God knows, no matter what sort of booty I might come upon, I should not be able to keep it if I had no satchel to put it in. After that I levied on each baker a tax of one half-penny roll so that I might treat no one unfairly and take too much from him, for I was confident that I should be able to get the rolls down dry, so that I should have no need of pissed-on cheese to accompany them to their destination. After this I sneaked around the marketplace like a fox around a henhouse when he is lying in ambush for a chicken or goose, and in fact, since I was invisible I might well have filched the one or the other person's purse together with his money, had I not considered myself too good to take up the despicable profession of the cutpurse.

Now when I had tired of strolling about, I went into the stateliest house I saw, where the yard was full of chickens, pigeons, capons, geese, and turkey toms and hens. Here, I thought to myself, I shall finally find something good for the gullet. And I was not deceived either, for the renter-warden himself, the highest official in the town, 
lived there, who, however, was an old man, lay mortally ill at the time, and for that reason, with the permission of his noble lord, had ceded the wardenship to his as yet unmarried son. I sneaked along after a lovely smell which led me to the kitchen, where the spit was turning over the fire, round about which were set large and small pots. I should have liked to have had some good warm broth, but just as no one gave me any because they were not able to see me, so I did not wish to ask for any lest I be seen and my presence noted; therefore I took a roll from my satchel and dunked it into a pot of stewing beef so often till I had refreshed my stomach so well that it made so bold as to ask for a drink. And I should have straightway satisfied its demands from the water barrel in the kitchen, had I not seen that shortly before the cook had peed into the water ladle, or dipper, and, after she had poured out her own water onto the drainboard, had put the ladle back into the water barrel without rinsing it off. I began to become convinced that I was predestined at this time to partake of this sort of distilled liquid with both my food and my drink. But I was not obliged to attendre so very long before I saw the cook take a hearty swig from a large earthenware bowl which she kept under that drainboard; which action I imitated better than a monkey while she was sticking several pairs of young pigeons onto a spit and was neither thinking of her bowl nor able to see it. So now my hunger was stilled somewhat, and I waited with longing for the kitchen door to be opened again so that I might look around a little elsewhere, which indeed did happen when the nurse came in and demanded a cup of soup for her master.

I sneaked out and came to a door where a peasant was standing and asking the clerk to announce him to the renter-warden, whereupon the peasant was straightway admitted, and I went into the room with him. The new renter-warden, who was the son of the old one, had about as much hair on his chin as a tree frog, but what he lacked 
there he made up for with his awesome periwig, from under which he peeked forth like an owl which is about to hoot. "Well," he said, after the peasant had finished his gramercies, 1 "what do you wish, my friend?" "Not much in particular," answered the peasant. "I should like to ask Your Grace for some advice, of which I'm sorely in need, which is the God's honest truth." And with that he fell silent and kept twirling his hat and picking lint off it, and at the same time looking at it as intently as if his business were with it rather than with the renter-warden. Thereupon the renter-warden spoke further: "Well, what do you wish? Speak up!" Only then did the peasant continue, saying: "My neighbor Val, that unneighborly fool, which is the God's honest truth, accused me of stealing his wooden mallet, which is the God's honest truth, and called me a rogue and a thief and my wife a whore and a witch, which is the God's honest truth. So I wished to ask most graciously how I should act towards him; I therefore ask the austere renter-warden, as my revered magistrate-which is the God's honest truth-to counsel me." The renter-warden answered: "If what he said is the God's honest truth, I counsel you not to bring suit against him." "Most austere and gracious Renter-Warden, you don't understand the matter aright, which is the God's honest truth. If someone called you a rogue and a thief, which is the God's honest truth, and your wife a whore and a witch, which is the God's honest truth, would you tolerate that?" "My dear fellow, that would be different," said the renter-warden and commanded him to withdraw and to appear on the next court day together with his adversary.

I went out the door with him, because I did not care to be locked up long in that office, and passed into a large cheerful room where a table was set for eight people, with everything on it save the food. From that room one was able to go through another door into the one wherein the sick man lay, which I surmised because I saw his nurse go in there with her soup. But in the large room stood two women, 
a young one and an old one, of whom the young one appeared to be very grieved and tearful, the old one, however, of somewhat better cheer. It seemed to me that they were taking very intimate and secret counsel with one another, and that pricked my curiosity to hear what they were discussing. "Yes, mother," the young one was saying as I sneaked up to them, "a thousand florins is a fine sum of money, to be sure, but it vexes me well nigh to death that this old husband of mine, while still alive, has turned over his office to his son. You cannot believe how hard it will be for me to leave this well-appointed household. As regards him, I really don't care, he can die or recover. He can't do anything anyway but fret and grouse by day and groan and fart by night. I have in fact often wished that it were the custom that when an old man makes a widow of a young wife and yet, however good a provider he may have been, has not taken her maidenhead, that after his death she should marry his son. But never mind what I wish! It is in vain, as all wishes are wont to be. Our noble lord should not have straightway bestowed the office on my husband's son, but rather should have shown greater consideration for a poor widow. If he had, I should have been well able to support some good lad who became my second husband and help him with bribes to obtain the office, which I feel sure I should have easily brought to pass if the office had but been vacant for only six months, and I should have continued to live in the renter-warden's house!" "Daughter," the old woman answered, "you certainly had it all well planned, but who can help it that it did not work? You must take consolation in the fact that you are returning home a thousand sovereigns richer anyway than when you left a year ago. That money, even though you had no hopes of inheriting anything from me, will soon get you a fine young man for a husband." "Yes," answered the daughter, "but the old man isn't dead yet. Who knows how long he'll lie there croaking?" 
With that both the doctor and the apothecary came out of the sick man's room and brought such unpromising news concerning the renter-warden's possibility of recovery that his wife, who was already grieved anyway, began to screech at the top of her lungs, and had I not heard what she had just said to her mother, I must needs have pitied her from the bottom of my heart. Because the parson too now straightway came to visit the sick man, the renter-warden's wife commanded that the meal be served. Thereupon a meal fit for a king was brought in, for they were entertaining theologii as well as medici, who ate and drank with a will to the good health of the sick man. At the table were sitting the parson, the doctor, and the apothecary; the render-warden's wife and her mother; the old renter-warden's son, who had now become renter-warden, and his clerk; and lastly another man whom they called the notarius.

Everyone at the table became so convivial and frolicsome that my heart leapt for joy; and in fact, why should I have grieved much, since the others were so little troubled over the demise of the sick man? The son was so saddened about his father that he jocularly told the guests how deferentially the peasant had kept repeating his catchphrase "which is the God's honest truth," at which the son laughed more than was seemly. Not a dish was removed to make way for other food from which I did not take my share, and with it I filled my trouser pockets and my satchel as well as my stomach; and it was a stroke of good fortune for me that they served the wine in pitchers with spouts, for I was able to suck a swallow from them whenever I wished without being obliged to pick them up or take them in my hands. In fact, I should easily have been able to fill my pockets full of silver beakers, but I feared that there might later be discord among the heirs and that great unhappiness might result. Anyway, I had made up my mind to steal from no one but a usurer who had excess money in his coffers and during the prevailing great shortage of money was 
allowing his coins to grow moldy and at no time permitting any of them to circulate among the people, save when he knew for sure that he would increase his pile by doing so.

Now so that I might find such a person, I quit the house in which they hoped soon to have a corpse. I put my shoes back on in order to fit my feet for the road and to wander on with full pockets and well provisioned, and half soused in the bargain, but before I went I wished to drink a St. John's toast ${ }^{2}$ and for that reason grasped a half-measure silver beaker which was standing on the wine table and drank so copiously from it that little more was left in it. But I did it so clumsily and awkwardly that they not only saw me put down the beaker again, but also heard me shuffle out the door, at which all the merry guests at the table were quite frightened.

"Now I believe," said the son, "that my father will not recover, for I indeed take this to be his ghost, and I am assured that he will attain eternal happiness, if the tale of yore be true that those persons whose ghosts are seen while they are still living attain eternal life."

I very nearly laughed out loud at that statement, but I did manage to restrain myself and waited till I had staggered out of the house and finally out of the village. And I did not stop walking till I reached some pleasant green bushes, where the wine, which really began to do its work in the fresh air, so overcame me that I was obliged to turn off, lie down, and sleep till dear bright day dawned once more. 


\section{chapter Seven}

That same morning I breakfasted right there in my camp on what I had brought along, but had no particular appetite for wine because the day before I had taken on somewhat more of a load than I was wont to carry, and in so doing had so heated my stomach that a drink of fresh water tasted better to me. On the food of which I had partaken I walked a good four miles without encountering anything worth telling about, and I should have gone on even further, had I not again felt hunger, thirst, and the need to rest at the same time. Another marketplace to which I then came seemed to me to be very convenient for satisfying my desires, that is, to eat, drink, and sleep. For that reason, after I had once more tied my shoes to my belt I turned in at an inn, in order to satisfy both myself and my needs; but the innkeeper (no disrespect to God's gift intended) had such a sour, gut-tearing, and sauerkraut-like ropy wine that after yesterday's it just did not taste right to me, even though I saw a fine opportunity to drink all I wished without any danger. 'Tis true that a little of this wine went a long way, for while I was there a party of eight travelers came along for whom one measure was more than enough, but who, as I could easily tell by looking at them, would not have been filled up by twelve measures, had the innkeeper had a different wine. When they had gone, after making sufficiently sour faces, the innkeeper's wife said to him: "I thought that would happen to you. You never let well enough alone! You should really have been able to figure that weak wine cannot tolerate as much watering as strong wine can! 'Twill serve you right if you are stuck with it and it spoils 
completely." "Be quiet, be quiet, you fool!" answered the innkeeper. "I'll improve it a bit by adding some of my better wine to it so that it will sell." I left these two to their quarreling and pondered on where I might get a better drink, and as I was thinking of this and that, it occurred to me that generally the most excellent wine is to be found in the homes of the clergy. Therefore I made my way to the parsonage, where I found the door ajar, because a woman had just gone out to do I know not what. I sneaked inside and right up to the parlor door, which, however, I dared not open lest I should frighten the people in the parlor, who were having a merry time together, or give them cause for suspicion that something strange was afoot. But because I should nevertheless have liked to get into the parlor betimes, I caught one of the chickens which was just then strolling past me to go to roost and so shook it that it began to squawk as if a marten were after it, for which reason the master of the house himself forthwith opened the door, not to let me in but to see what the devil might be after his chickens. But I went in anyway and found a full glass of wine on the sideboard and a pitcher on the bench next to it, which pitcher I robbed of half its contents before the parson and the woman who had been in the room with him came back from the chickens, which happened too quickly for me to skip, much less to be able to get back out of the room.

The two resumed the discourse which the squawking of the chickens had interrupted. He was half drunk and therefore all the freer with his words. "Yes, dear Susanna," he said, "'tis not so great a sin as people make it out to be. The patriarchs of old often strayed from the straight and narrow, and as a matter of fact they kept mistresses and concubines and not a one of them was damned because of it." With that he pressed the little woman's hand and began to fumble about her breasts, so that it appeared that the praeludia Veneris were about to begin in earnest; but the young woman still had rather much 
control of herself and said: "If it is not a sin, then why do you gentlemen preach so dreadfully against it?" "Hah!" answered this fine little man, "That we must do because of your jealous husbands, for were they to know, as we do, that it is not so great a sin, think how disorderly life would be, and how many a man would lose his life because of it! That is why we must keep this a secret from them." I thought to myself: Oh! You scoundrel! A lie like that deserves a punch in the mouth, and I was of a mind indeed to give him just that, as I recently had to the Calvinist, not only to punish him thereby for his godless lies, but also to drive the prickings of the flesh out of him. But I thought of something better so as not to lay violent hands on one of the annointed of the Lord.

But when I saw the woman in danger of losing her honor, and both of them were already quite a good ways down that road, I took pity on her because of her innocence and because she was about to be plunged into damnation through the falsity of the very person whose calling it was to show her, through the truth, the way to eternal life. For that reason, as he was about to go the last mile I seized him around the middle and tucked him under my arm like a feather (for in weight he was as trifling as were his words) and rushed out the door with him into the yard, where I swished him around in his own cesspit till he looked as well greased as a leg of veal ready for roasting. After that I dragged him up on the dung heap so that he might recover a bit and so that his clothes might drain off a little. The young woman whom he had meant to seduce came out of the parsonage, and contrary to nature's custom, looked much greener about the gills now that the danger was past than when it had been the greatest. I, however, remembered the pitcher in the parlor and therefore went back to it and caressed it so lovingly that not a drop was left in it.

After this I sat down in a corner and reflected on what I had seen and heard the two do and on what I had done myself. I did not repent 
of what I had done, and because of what I had seen and heard I was no longer surprised that there are lewd hussies who lie with godless clergymen (I say "godless clergymen," because pious ones will shun not only wanton whores but also respectable matrons), even though it has been said a thousand times and there are ten thousand examples that clergymen's whores are damned in all eternity and become the devil's own mounts. ${ }^{2}$ For, dear reader, why should such intrinsically weak, simple-minded, and preternaturally lewd creatures as women not be more apt to believe those who are held in such high regard and who claim to know all the hidden mysteries of the Scriptures, when they tell them with such great assurance the very things they wish to hear, are glad to comply with, and wish themselves that they were so?

During these speculations of mine, the parson had recovered somewhat and realized where he was, but for all that, still did not know how he had so quickly fallen from such pleasant delight into such a loathsome plight. The sudden fright had so rattled him that when his housekeeper, who had just then returned home, began to question and fuss over him, the only reply which he was able to make was: "Leave me in peace!" And when she did not leave off fussing over him, he finally said: "Leave me the hell alone!" But she took him into the house, into the parlor, and with the help of her brother, whom she had sent for to aid her, finally into his bed. How the fright agreed with the little woman I cannot say, but it is my opinion that she will remember this encounter sufficiently well that she will never again allow a clergyman to go as far as this one did.

I should have paid it no mind, had I been out of the parsonage once more, even though I did not know where I should turn in for the night, because it was already rather late. But I was held right there by the good wine, of which I was confident I might guzzle without damage to myself as much again as I already had in my belly; and 
this I succeeded in doing, but it did not agree with me very well, for when the maidservant went into the cellar with her brother (who was obliged to hold the light for her so that she would not be afraid) in order to fetch a two-measure pitcher of wine for the two of them to drink with supper, I sneaked along. But she never let the pitcher out of her hands, so there was no way I was able to get at it. Now since I did not wish to leave the cellar without having taken a drink, for I had already learned how difficult it is to take a drink unnoticed when on the table there is only one pitcher, I therefore let them lock me in the cellar, even though I saw no vessel from which I might drink, for my hat was good enough for that; besides, I had enough food left from what had been prepared for me in the renter-warden's kitchen to last me for a good three days.

Now when the abovementioned two went away with their wine, I drew enough from the keg for myself, doing it nice and softly so that no one might hear me, which precaution, however, I might have spared myself, for, sitting on the stairs, I had hardly eaten and emptied a hatful of wine down my throat when I heard that there were yet other invisible guests present who were knocking on the wine keg far less timidly than I had. Naturally, that made me feel as if I had as many ants on my head as hairs, scurrying about like soldiers when they hear drumrolls call them to hie to their weapons or to execute a contre-marche. The more time went by, the louder the din became, and with it the greater my fright too, so that the fear which I had put into the master of the house and little Susanna was doubly repaid me. Finally, I heard wine being tapped, barrels being coopered, filled and carried up and down the stairs, for which purpose the door was quite conveniently opened, although I was able to see no one who was performing all these actions. I wished to get out the door and be rid of this terror, but halfway up the steps I received such a blow that I tumbled back down the stairs and lay there till daybreak, even 
though, save for my incomparable fright, I was not especially injured by the fall.

Now when with the break of sweet day everything had passed and I again had all my five senses, I finally understood why the housekeeper had fetched such a large pitcher of wine all at once, namely so that she might not be obliged to go into such a spooky place a second time. I thought to myself: Let this be a lesson to you for the rest of your life, not to insult any clergyman ever again, since the spirits avenge them so terribly. In the meantime my fright left me little by little, and in fact so completely that I thought once more of food and drink, of which I partook again despite my difficult situation, and waited with yearning for the cellar door to open, which, however, did not happen till the housekeeper's brother fetched a fresh drink for the barber who had bled the parson. Then I ran out as if the bailiff were after me, and even the very greatest thirst would not have compelled me to go back down there, even if naught save Hippocras ${ }^{3}$ and Malvoisier 4 had been laid down there.

As I walked across the yard the parson was lying at the window for a breath of fresh air after having been bled, and I well saw from the look of him that now he was lusting after neither women nor virgins, neither concubines nor wives, much less after Susanna, and I believe that if anyone had been able to see me, he would have seen the same virtue in me, so lame was I still in all my bones, unless the breakfast I had eaten had imparted to me a better color than being bled had to the parson. Just then, to help me continue my journey, two poor studiosi came along who asked the parson in Latin, as a matter of professional courtesy, for a viaticum, and straightway he quite generously sent them on their way with two farthings. Now with them I easily got out of the parsonage yard and through the gate, which I should not have opened myself, even had I been obliged 
to wait impatiently for yet two more hours, because, of course, I desired that my presence there should remain undetected. 



\section{Chapter Eight}

With these two students I continued on the road which I intended to take anyway and soon remarked from their discourse that one was a theologus, or at least thought to become one, whereas the other one still faced the decision of whether he wished to become a jurist or a medicus. The first one said to the other that during the next disputatio he was going to undertake to affirm the tractatus Isaaci Peyrerii de Prae-Adamitis (in which he had presumed to prove that there had already been human beings on earth before Adam). ${ }^{1}$ The other one, however, answered him by asking whether he did not know that this same author had recanted and condemned this erroneous opinion of his. On top of that, it would not behoove him as a Christian theologo to agree more with the lies of the Egyptians and other heathens ${ }^{2}$ than with the clear word of God and the interpretation of the Church Fathers; one found it stated clearly enough in the Holy Scriptures that Adam was the first created and before him no other, and therefore there was nothing more uncertain in the world than tales someone might babble about what is supposed to have transpired before the Deluge (save for what is reported in Holy Scripture). "You remind me," he continued, "of those who, like the old heathen philosophers Epicuro, Democrito, Anaximandro, Thaletis discipuli, Metrodoro, Anaximene, Aristoclo, Archaelao, Xenophane, Leucippo, Diogene Appolloniate, Anaxarcho and others, wished to dream of many other worlds than our own. ${ }^{3}$ Would not anyone who spread such ideas be like Luciano, who sailed through the air to the sun, the moon, and the stars and found them inhabited by people and 
animals?4 Anyway, I should like to hear how, dear sir, you intend to prove the existence of your pre-Adamites." "How?" answered the other. "From naught save Holy Scripture itself. For when God Himself asked Job in his thirty-eighth chapter 'Where wast thou when I laid the foundations of the earth? declare if thou hast understanding. Who hath laid the measures thereof, if thou knowest? or who hath stretched the line upon it? Whereupon are the foundations thereof fastened? or who laid the cornerstone thereof?' then He added to that and said 'When the morning stars sang together, and all the sons of God shouted for joy?' And these very people were the so-called pre-Adamites, who are here called the 'sons of God' and whose race lasted down till the Deluge, especially since we read in Genesis 6 that the sons of God saw the daughters of men (that is, the daughters who were born of Adam's race), that they were fair, and they took them wives of all which they chose, and of them were born giants and mighty men in the earth, men of renown, because of which miscegenation, mainly, the earth was visited upon by the Deluge, in which the pre-Adamites also were annihilated and extirpated; which same miscegenation was so displeasing to God that because of it after the Deluge He extirpated the Sodomites with fire and brimstone from the face of the earth 5 and most sternly forbade His chosen people, the Israelites, that sort of behavior, even in the slightest matters; for which reason the Jews, to this very day, are not permitted to wear garments of half wool and half linen, to hitch two different kinds of beasts before one wagon, to sow two different kinds of crops on the same field, or even to cook two different kinds of meat in the same pot, and many other things of that sort."6

"Nonsense! Nonsense!" answered the medicus or jurist (I really know not what he has since become). That which is written in the Book of Job is in regard to the holy angels; and the 'sons of God' in Genesis 6 were the sons who sprang forth from the tribe of the holy 
patriarch Seth and who were surely reared in the fear and love of God, but who married into the tribe of the desparate fratricide Cain, despite the fact that their pious parents, at God's command, forbade them to do so. So, my dear sir, if you have no better arguments to put on the table, you'll lose the disputatio."

The theologus, for his part, said: “The hallowed angels were most certainly the sons of God; but when the world was created Lucifer and his band had already been cast out of heaven, else he should not, out of envy, have deceived Eve. Now if Lucifer and his band, by virtue of their creation (for everything God created was good), as well as the hallowed angels who remained faithful to God, were good, and the sons of God, but damned after their fall from grace, then how can God say to Job that all the sons of God shouted for joy, since after all, no praise of God comes from the damned, and since, as some maintain, one-tenth of all the hallowed angels rebelled against God, or, as others claim, the serpent dragged a third of them down with him? So much for point one. Now as to point two, namely, the sons of God whom Moses mentions in Genesis 6: Even if the miscegenation, displeasing to God, between the tribes of the blessed Seth and godless Cain, who intermarried, had bred and brought forth giants, a third race as it were, then certainly God in His goodness could not have been so highly displeased at marriages between one people and another, both of them born of Adam, that He would send the Deluge on that account; further, even if this were indeed the case, I could not see how the Sethites and Cainites, both born of Adam, would be able to bear and bring forth a third race so unlike either of them-that is, giants. Therefore, the people who married must needs have been the pre-Adamites mentioned in the Book of Job."

"Fiddlesticks! Fiddlesticks! Fiddlesticks!" said the other. "We only know of one human race, namely our own, which was created to take the place of the fallen angels, and from which race was also born the 
Saviour of the world, through whom we poor sons of Adam have been set aright once more, to enjoy the blessedness of selfsame angels, unless we choose to walk the broad and easy path to you know where. I no longer wonder that there have been, always and everywhere, so many factions and heresies, when I see that even now every visionary is intent upon proving, on the basis of Holy Scripture, his silly notions and foolish crotchets, when in fact all of us should be striving, in fear and trembling, to achieve our own salvation.

"Let us suppose (but not concede), my dear sir, that you prove indeed that there were pre-Adamites: Of what use will that be to your own salvation? Of what concern are the pre-Adamites to us Adamites? Our Lord God doubtless had His most holy reason when $\mathrm{He}$ did not cause everything to be writ down in Holy Scripture, particularly that which is not actually necessary for our salvation! What need of all this brooding about whether pre-Adamites existed or not, since they, or our knowledge of them, can neither help nor hinder us on the path of Christ our Saviour which all of us should be following?"

"Such knowledge," answered the theologus, "will surely not harm us either in respect to our salvation. We ought to contemplate diligently God's wonderful creatures and praise the Creator in all His works. Wise Ecclesiasticus says this beautifully when, in Chapter 43, he admonishes us to praise God, saying: 'We may speak much, and yet come short: wherefore in sum, He is all. How shall we be able to magnify Him? for He is great above all His works. The Lord is terrible and very great, and marvelous is His power. When ye glorify the Lord, exalt Him as much as ye can; for even yet will He far exceed. Who hath seen Him that he might tell us? and who can magnify Him as He is? There are yet hid greater things than these be, for we have seen but a few of His works.'7 Moreover, my dear sir, you well 
know that we do ourselves no small honor when we are able to set forth such new findings and defend them in public disputationibus."

"Oho!" answered the jurist. "Is that what ails you, my dear sir? But you should bear in mind that almost all heresies began this way. The blessed and ingenious Thomas à Kempis says that it is better to possess humility than to be able to discourse on it at great length; 8 and the old proverb is more than true enough when it says that you can't tamper in the least with three things without doing them irrevocable harm: faith, the human eye, and the maidenhead. And why should we burden ourselves with such specious arguments when we see every day with our own eyes, if we but take the trouble to look, enough of God's wondrous works to inspire us to praise Him; and we have no need to invent strange and unheard-of creatures as Theophrastus Paracelsus does in lib, de Nymphis, Sylphis, Pygmaeis \& Salamandris, \& c. ${ }^{9}$ and as Heinrich Kornmann does in Monte Veneris, 10 especially since we must take care that the accursed devil not deceive and trick us mortals by assuming the shape of such nymphae (or water sprites), pygmaei (or mountain gnomes), sylphis (or air sprites), and salamandri and vulcani (or fire sprites)."

During this discourse we came to a place where a footpath through the forest turned off from the main road, for which reason my two studiosi were obliged to choose which of the two they desired to take; and after they had stood there for a while, a man approached whom they asked about the right and most direct way to the village ahead of us. ${ }^{11} \mathrm{He}$ told them to take the footpath and said that it was an hour shorter and also better to walk on than the main road, and that he himself had in mind to betake himself on it to the aforementioned village. This fellow led the way, both students followed him, and I brought up the rear. We had been walking hardly half an hour when I perceived that the further we went, the more impassable the 
path became and the thicker and wilder the forest, for which reason I began to suspect the worst. However, I relied on my invisibility and on the fact that we were traveling through a country which was at peace; I also thought that the two students would not be such children or cowards as to permit themselves either to be kidnapped or robbed so easily, since each carried in his hands a sword instead of a cane. But while I was turning these thoughts over in my mind, a fellow with a blunderbuss jumped out behind me and cried out to my two companions to surrender, and the moment the two turned round to look at him, the man in front who had led the way wrested the sword away from the theologo; the other student, when seeing himself forsaken and himself and his disarmed comrade up against two armed men, took such fright that he looked as pale as a ghost and lost both heart and his sword, which dropped from his hand, and, along with the other one, begged the two footpads for mercy and pity.

But these two were deaf to the students' pleas and forced the poor ninnies to leave the footpath and walk to a more secluded place in the forest. I sneaked along with them to see what they intended to do with the two good scholars, till we came to a place where they were obliged to sit down and strip to their shirts, of which each was wearing three; then I heard the most pitiable words which each uttered in an effort to save his life, although the two highwaymen had not yet said what they were after, but rather, as mentioned above, acted as though they were deaf and dumb. It was not enough that each was obliged to strip down to his three shirts; they were even forced to take off two of the shirts, keeping on only one, which gave them to understand clearly enough that the shirt they still had left was to be their shroud or winding-sheet. Because of this they began an even more pitiable lament than before, such as should have moved a stone to pity and compassion, but the two monsters remained so 
completely unmoved that I could not but wonder at it. "Alas!" said the one student to the other. "Had we only learned not vain follies, idle nit-picking, and silly disputations, but rather how we should die decently and like good Christians!"

Now when it came to the point that one of the brigands cocked the gun to finish off the one studioso, I stepped to him and tore the piece out of his hands so quickly and violently that it went off and the shot flew harmlessly into the air; and in a trice I reversed the piece and knocked that murdering thief in the head so hard that he dropped to the ground like an ox that has been pole-axed by a butcher. The blow, the fall of the man I hit, the disappear- and discharging of the piece, and the deliverance of the student who was about to die all happened in an instant and at such an unexpected moment that the comrade of the man who was lying there unconscious was astounded and, all pale in the face, stood stockstill, like a stone statue, facing the other student. That did not bother me in the least, and I walked over and gave him such rude digs in the ribs with the piece that he writhed like a snake and finally took to his heels in such fashion that his feet carried him off as fast as if the devil were either chasing him or even carrying him off.

I sat down a little while to see what the students would do now. They got dressed posthaste, as it were, and gathered their things together as hastily as if they were stealing them. But when the fellow whose comrade had run away and whom I had knocked down came to his senses somewhat, so that he moved and tried to get to his feet, the students seized their swords, went at him, and were about to run him through, so that I was barely able to hold back both of them and keep them from carrying out their vengeful purpose, for which reason I was obliged to speak, were I to save that fellow's life, saying to them: "Can you not comprehend that if at this time the commission of a murder had been permitted, you two would have been the first 
who would have been obliged to die? If, however, you wish to see this man punished for his crime, then take him and deliver him to the law!" At these words they were so affrighted that they forthwith left off, particularly when they felt their arms, by which I had grasped them, in the clutch of an invisible power which was hindering them in their undertaking. But nevertheless, they had no desire to seize the highwayman in order to turn him over to the authorities, but instead let him escape into the woods. For them it was enough that this time they had escaped death, and what did it matter to them (they perhaps thought) what further crimes the fellow might commit, and therefore they felt no need to bother themselves further about him.

Now when they had gotten dressed again, had shouldered their few belongings, and had recovered from the great shock they had experienced, only then did they think about how wondrously they had been saved from death. They were unable to believe that because of their merits they had been deemed worthy to receive from God such palpable help through their guardian angel, and yet they were unable to imagine either that the devil would have prevented such murder and mayhem; therefore they once more delivered themselves of all manner of erroneous notions and foolish crotchets, for no other reason than that they did not know the power of my bird's nest, for otherwise it is to be hoped that their discourse would have turned out differently. They knew not whether the manes or the lemures, the coelites or the inferi12 had aided them in their hour of need, and I believe that if I had not been loath to talk further with them, in my invisible state I should have been able to persuade them that I was one of the above-mentioned Paracelsus' or Kornmann's airy sprites or gnomes, or even one of Lucianus' men in the moon, or the ghost of a pre-Adamite dead now these hundred thousand years. 


\section{Chapter Nine}

After that, I let them go on their way alone, and it tickled me that I, an uneducated idiot, knew the reason for what had happened, while they, highly educated fellows, were obliged to guess at the reason and were not better at it than a blind man is at judging colors. The captured gun I smashed to pieces against a tree because I had no need of any weapon, and then I wandered on to the next marketvillage, where I arrived at the inn just as a wedding feast was being celebrated with food and drink and the dance was beginning; for which reason a great crowd of husbands and wives, youths and maidens, were leaving the tables and hurrying to the dance floor, save for a few aged topers and old crones, who remained in their seats, the men discussing their farms and talking about the old days and how weddings were celebrated in their time, the women either bewailing the misery caused by drunkenness or, in typical feminine fashion, making catty remarks about all manner of folk, both single and married, condemning some because they had dressed and appeared in clothes that were too splendid and others because they had dressed too simply. I should have enjoyed listening to them, had I only known the people whose wealth they were able to estimate so accurately and whose morals they knew how to criticize and dissect so nicely, but since I did not know any of them, it was no fun for me, so I snatched here and there from the table food both roasted and baked, and stuffed my stomach, as well as my satchel, so full of it that I found myself sufficiently provisioned for a full week, and also quenched my thirst as manfully at the innkeeper's wine counter as if 
two people had been drinking. After that I wiped my mouth as any other parasite would and went to see how the dancing was going, at which I observed the crude young peasant rabble groping and handling one another's flesh as artfully and expertly as any fifty-year-old butcher who knew every trick of the trade. ${ }^{1}$

Now when I had seen enough of this, I went out of the barn where they were dancing and into a stable and lay down in the furthermost corner on a pile of straw in front of the mangers to sleep off both my tipsiness and my fatigue. But I had been lying there for hardly half an hour when a hired hand came in with a servantgirl who, to judge by the way she talked, was either a Swabian or at least had lived with Swabians for a long time. I thought they were going to feed the cattle, but they had in mind a different diversion. As best I could tell from what they said, the wicked rascal was tickling the good wench so that she said over and over again: "Stop, oh do stop!" But he did not leave off what he was doing, but instead suggested to her, with gestures I suppose (for since it was dark I was not able to see, and since he did not say anything I was not able to hear what he proposed to do), something impudent which she, however, did not wish to permit, saying that if it were to go that far, he would go further, till finally the fellow swore by all that is holy, yea, said that the devil might take him if he did more than just put it-know not what-against it; but the wicked rogue did not keep his word with the poor ninny, for straightway after that she said: "Ow! Now the divil's got ya, got ya, got ya, etc." and she continued to say this over and over again for some time. He, for his part, answered every time, saying "So let the devil get me, get me, etc."2 Now the longer this went on, the louder their voices became and the faster they shouted, just as if they had agreed to do it posthaste, which strange litany seemed so ridiculous to me that I was hardly able to keep from laughing. But as soon as I laughed out loud, I also spoiled their sport, for as close as they had 
crept to me before, just as quickly did they now run away from me again, and left me in peace to sleep as long as I desired. 



\section{Chapter Ten}

The next morning, however, I was obliged to get off me arse all the earlier, for when the maid sang while she was milking the cows, she woke me up, and when she turned them over to the cowherd, I went on my way and in two hours came to a pretty little town, around which were beautiful gardens, planted both for pleasure and for profit, for which reason I was not able to forbear to go into one of the prettiest ones, because the gate to it was ajar, with a mind not only to feast my eyes but also to loll about a while in the shady greenery.

Straightway upon entering I passed a walkway lined with shrubs gracefully intertwined, along the sides of which divers servants were hurriedly sweeping clean with brooms the pathway in a beautiful flower bed, from which servants' talk I learned that a splendid banquet was to be held in the garden that noon. I walked further and came to an imposing house in which they were likewise cleaning up, setting the table, pouring cold water, polishing glasses, and preparing in the kitchen a magnificent meal. The hall in which the meal was to be served was furnished most pleasantly, the chairs upholstered in velvet and covered with bolsters and pillows beautifully embroidered in the modern as well as the classical style; ${ }^{1}$ the floor had been sprinkled with rose water, and next to the table, which had been set, the floor strewn and adorned with all manner of beautiful and sweet-smelling flowers, while the walls were covered not with tapestry but were hung with the most artful paintings, and the sideboard was filled not only with precious crystal glasses in all manner of shapes but also with drinking vessels of gold, silver, and gold plate. 
Now just as the garden would have been Paradise enough for me, had it only lasted forever and should I have been permitted to live there always, I could not but be even more astonished by this hall; in summa, it looked to me so like a display case or at least like an artful painting that I almost did not believe my own eyes, but rather imagined that this feast for my eyes was perhaps merely a dream.

I had taken off my shoes and hung them on my belt, as I was always wont to do when I sneaked into a house, so that the people would be all the less apt to hear me tramping about, and thus my desire to see everything in the house caused me to proceed all the more boldly. First I came into the kitchen, where the roasting spits were turning by themselves and pots were sitting round about the fire; all the walls were covered from top to bottom with metal, copper, brass, and pewter ware so brightly polished that it seemed as if I were not in a kitchen but somewhere in a steel mountain. On top of that, the half-cooked foods presented such a delicious aroma to my nose that I felt an appetite to eat, even though I was not yet hungry.

From there I climbed up a spiral staircase and came into a hallway from which I was able to look into several rooms, each of which was furnished with a canopy bed with costly drapes, a table with several easy chairs, and walls decorated with tapestries of golded leather. Now while I was gaping at all this, a door opened and a maid with a silver perfumer stepped out; she left the door open, therefore I sneaked in and came into a room so beautiful that it would have been good enough for even the King of Morocco to live in; yea, it far surpassed the aforementioned hall, despite the fact that no preparations were being made to eat here. The very first thing I beheld in the room was a lady who was standing before a large mirror and primping, but she had actually finished with that, and had all manner of rouges, pomades, tormae solis, 2 oleum talci, 3 tooth and hair powder, distilled water, and the like, enough to fill half an apothecary's shop. 
She was only waiting for the maid to return with coals so that she might put little black beauty spots here and there on her face. In the meantime she engaged in all sorts of monkeyshines before the mirror: she leaned forward; she looked to see how her laughter became her; she pressed her lips together, and then changed the shape of her mouth in all sorts of ways, just as Pickle Herring changes the shape of his hat, ${ }^{4}$ and made her eyes sparkle as if they were caressing her own image in the mirror. In summa, she engaged in such tomfoolery that I was hardly able to restrain myself from laughing out loud. Now while she was thus enraptured in worship of herself, she suddenly glimpsed my silently laughing face in the mirror (for my bird's nest was not of the sort which made one invisible in the water or in a mirror, of which, however, I was at the time unaware, else I should have taken better care), at which she forthwith turned around to look behind her, and when she saw no one there again looked in the mirror, in which she once more beheld me, which so frightened her that she let out a loud scream and turned pale as a ghost.

All atremble she sat down in an arm-chair, clapped her hands together and her eyes heavenward, from which I was easily able to surmise that she had seen me in the mirror and taken me for an apparition from hell who was mocking her vanity and folly. For that reason I trundled out of the room, for the door was still open, and came to the spiral staircase just as the maid came running up to see what was ailing her mistress. She, however, refused to say what had happened to her, but instead engaged in pitiable laments, showing that she was indeed repenting of her folly. I, for my part, scurried down the stairs, and since everyone was running up to see how the young lady was faring, I found the hall completely emptied of everyone and some decanters of wine standing in cold water. I grabbed one of these and took a little sip of about three quarts out of it, and thereupon betook myself to the wondrously beautiful garden, looked at the beautiful 
garden, looked at the beautiful flowers and rare plants, and during this stroll, to while away the time, munched on a piece of white bread and roast beef, of which I still had a rather good bit in my satchel.

No more than a quarter of an hour later several ladies and gentlemen arrived, and also the young lady's parents, to whom this garden, the outbuildings, the house, and everything else belonged, which parents heard with great sorrow from the servants that their daughter had been taken ill. Everyone ran to come to her aid, but because she would not reveal to anyone what had befallen and was perturbing her, there was no way of consoling her either. Instead, she behaved in such fashion that one might have assumed from her continuous sighing that she was somewhat touched in the head, although what she said was still fairly rational. They sent for the medico, whom her mother told that when she had sent her dear child to see to it that the forthcoming meal should be prepared properly, she had been hale and hearty, but now, alas, she found her in this miserable condition. The doctor, however, could make nothing of her condition, but said that it must be the result of either inordinate worry, fear, or an unexpected shock. I was vexed at myself that my presence had caused such a sad alarm and should have spoiled such a magnificent feast in such a delightful place, particularly since when I first arrived everything had reminded me of the hall to which beautiful Psyche had been carried off, yea, the patient herself had reminded me of Psyche. ${ }^{5}$ Indeed, I was so perturbed at myself that I deemed myself a veritable harbinger of ill fortune. My greatest consolation was that if the young lady were to die, as her mother feared, it had all happened against my will.

Amidst this sad confusion the gentleman arrived in whose honor the entire company was assembled and whose presence had caused them to foregather there in order to see and judge whether a marriage might be arranged between himself and the oft-mentioned 
young lady. He was a handsome fellow, attired and decked out as rich and fashionable dandies of our time are wont to be. Now how he was greeted and whether they also straightway permitted him to wait upon his deathly pale beloved I do not know, for I was still walking about in the garden, suffering from pangs of conscience because I had endangered the life and well-being of so beautiful and distinguished a lady. But it was not very long at all till all sat down to eat, whereupon I saw that the young lady was sufficiently recovered to sit down with them, although it seemed to me that she was still very quiet and sad, and had forgotten all the lovely and charming faces and gestures which she had but recently been practicing before the mirror.

Everyone present spoke to her in naught but honeyed words and honored her like a goddess. The butler served her like a slave, and at the doctor's advice musicians were obliged to perform before the meal so that her distraught spirits might be again assuaged and recreated, from which the good young lady gradually revived once more and blossomed in a fine healthy color. In summa, she was soon feeling much better than I had dared hope, and straightway thereafter the party became so lively and merry that I took this life to be an illustration of the one led by the rich man in Luke 16.6 Therefore my conscience was again at peace, and I myself right merry and so bold that I went up to the young lady's room, because now it was empty of people, stood there before the mirror and in this way confirmed for sure that I was not invisible in it, since I saw my own figure in it. Following that, I came into an antechambre where there were sweetmeats which were so lavishly prepared that I could not but be astonished, because I had never before seen the like. There were entire towers and castles made of marchpane, whole platters full of all kinds of fruit, yea, hams, saveloy, and that sort of tidbits, made entirely of sugar, painted, gilded, and decorated with flowers, not to 
mention candies and preserves. I must have stood there for better than an hour, till I had had my fill of looking at everything. After that I went back into the dining hall. What had not been eaten from the first courses had already been removed and others served. There I saw all kinds of pasties: on one of them stood a beautiful pheasant in its natural plumage, as if it were alive and about to fly away; on another a capon; on a third a capercaillie; on a fourth a brace of blackcocks, and on a fifth several partridges; and so on. On some only the feet of a hare or the head of a bird peeped out, on others the hoofs of a stag. I very nearly lost my wits over them, because it all seemed so outlandish to me. I deemed a roasted suckling pig particularly fortunate, because it had a lemon in its maw, which would have been filled with slop, had it lived to a proper sow's age. More and better choice morsels were left on the plates than were eaten, but I should much rather have preferred a good warm broth in my stomach.

Therefore I sneaked into the kitchen to see whether I might get such a bowl of soup, but there was none to be had there. However, I did come upon a French potage, which is a kissing cousin to the Spanish olla podrida; ${ }^{7}$ to this I addressed myself right heartily, because it happened to be standing by the fire, and in that good broth there were among other things some very choice morsels. I especially enjoyed the gizzards of all manner of fowl, the morrels, and the little pieces of Spanish bread, 8 which I used instead of regular bread, just as I did my fingers instead of a spoon, since this fine grub seemed to have been prepared to be eaten this way.

Now when I had bolted down my fill, I too went into the hall to drink, and grabbed from the sideboard a half-measure goblet of Hippocras, which I at first took to be good red Jochem, ${ }^{9}$ and I emptied it right down to the very bottom. After that I stood there and observed with astonishment how little and how slowly some of the guests ate, just as if there were nothing good on the table before 
them. God forbid that I compare anyone to fatted pigs, but some of those fat paunches were in fact just as bored with their food. They sat here over their meal, yet the sumptuous foods by no means satisfied their taste, while, by contrast, the other four senses experienced far greater pleasures, for the musicians delighted the ear, the welladorned hall and the splendid table the eye, the mild air and the soft seats the sense of touch, and the aroma of foods, flowers, rose water, and incense the nose.

In the meantime the people slowly began to become a little tipsy, and who would not have, after pouring the wine so neatly down his gullet? And even though it was pleasant to be in this hall, once I had eaten my fill I should have sought peace and quiet somewhere under a shady tree in the garden, had a fellow with a viola da gamba (or bass viol) not performed so lustily that it detained me. This fellow's playing so pleased the dandy that he tossed him a whole handful of shiny new guilders, all of the same minting, two of which rolled so close to me that they seemed to be imploring me to have mercy upon them because of their beauty and to pick them up and put them into my pocket, which indeed I did, without delay. Of course, I was not in the least of a mind to steal anything there (picking up money which someone else tosses out and throws away is something different), else I should have been able to easily pick up as many silver goblets as I might carry, but I was satisfied merely to empty a few more of them, and when this began to make my head spin, it seemed to me to be time to make myself scarce, and therefore I took a saddle of venison and a roast hare with me, because they perchance had kept one another company in the woods too, perhaps had even been caught together, larded with the same bacon, roasted on the same spit, and now had been taken from the same table at the same time.

These I took under my arm, for my satchel and my trouser pockets were already sufficiently stuffed with victuals anyway, whisked 
out of the house and garden, and when at the city gate I remarked that the dogs there were able to smell me, even though they were not able to see me, I went a roundabout way. After about an hour or an hour and a half I came to a village where I climbed into the hayloft of a miserable cottage which was some poor soul's home, and lay down to sleep on some dry goat fodder lying there, which suited me exceedingly well. 


\section{Chapter Eleven}

At sundown I was awakened by a clamour, for which reason I got up to see what the to-do was about. It was a beadle with two soldiers who had seized a goat from my host, who had just then come home from work with his wife and children (of which he had with him altogether eight little urchins); and they were leading the goat away because he owed fourteen groats in manor taxes, as they called them. The wife clasped her hands over her head and cried out continually and without surcease: "Oh, God in Heaven above, have mercy! Wherewith shall I now feed my poor little children?" The children, for their part, were all crying out at the same time: "Oh, our nanny! Oh, our nanny! Our nanny!" The husband begged the executors of the judgment to be patient for just one more week, pleading by God and in the name of God, of His passion, of all the saints, and of the Last Judgment, but to no avail. He entreated them even more fervently, but in vain! They simply walked off with the goat and left the poor man, together with his wife and children, to lament as long as they would. Wringing his hands, the man went into the living room of his wretched quarters, his wife and children after him with pitiable howls and cries, and I followed with deep sympathy in my heart. "Alas!" he said. "'Twould be no wonder if one were to do what God bade him never do! I have not a farthing even to buy salt! I have not even any lard for a broth! Despite all my toil and trouble, because of these oppressive taxes I have scarcely enough left to feed my poor children even a crust of bread! And in addition to all this, these slave drivers come and take 
away the most valuable thing in the house. What am I to do now, if you are to be deprived of both lard and milk?"

He howled more doleful words of that sort in a deep bass voice, his wife accompanied him in a wretched tenor, and the various children (who with their different sizes represented, as it were, the pipes of an organ) provided the alto and soprano voices, so that together they produced a harmony of most lamentable music ${ }^{1}$ which moved me, not without reason, to pity and Christian compassion, and made me reflect on what a difference there was between this life of misery and the other sort of life which I had witnessed earlier that day. I thought to myself; today you were in the rich man's house, now you are in the house of poor Lazari.2 But I rejoiced about one thing: namely, that the father, mother, and children were all hale and hearty, which was not the case with Lazaro.

Now when I thought back on the noon meal today, I also remembered the two guilders which I had taken as booty at it, and pulled out one of them and threw it on the table so that it clattered. The poor couple was affrighted, to be sure, but they soon recovered again and said as one: "This the Dear Lord has given us to redeem our nanny."

And the poor man ran off straightway with the guilder to ransome his goat, although it was already rather dark. The wife and children, however, were well consoled and gave thanks to God for the money which they had received. Then she began to cut up bread to go in the soup, and awaited with longing the return of the goat so that she might boil its milk for the soup which she was preparing, and to this end she made a fire on the hearth, in which the children, to still their hunger, in the meantime roasted carrots; but some of them stealthily snitched from their mother some pieces of the bread meant for the soup and ate them so surreptitiously that they did not even move their lips, but rather allowed the bread to melt in their mouths and then swallowed it down. 
In the meantime the husband came back with the goat and reported that the scoundrels who had enforced the judgment against them, or "hexecutioners," 3 had not only milked the goat dry, they had also pocketed as their fee the change from the guilder, with which he was supposed to buy salt, which caused another lament from the wife and children, for now she knew not how she would be able to cook any soup, since there was no salt, lard, and milk.

However, so that the children might at least have something warm in their stomachs, the mother took an egg (for this household also boasted a laying hen), stirred it into the water, let it boil, and shook every last grain of salt out of the salt bag and over the pieces of bread; and when this meager soup had been put on the table, large and small sat down and, after saying grace, attacked it with their wooden spoons, so that not a drop of it was left in the bowl. And did these people not have a different appetite than those fools in the garden today? The table (I could tell by its artful construction that the father had made it himself) was, to be sure, so crowded with starving children dressed in rags that no one else could sit at it, but I was able to reach over them quite easily, and because I pitied their wretched misery, particularly since besides the roasted hare and the saddle of venison my satchel and trouser pockets were filled with all manner of pieces of meat, roasts, white bread, and such-like wares; also because I perceived that both husband and wife accepted the money as a special gift which God had wondrously bestowed upon them, I opened my generous hand even wider and began to put before the children, one after the other, goodies from my trouser pockets, for after soup the father had not wished to cut another piece of bread for them, and indeed, he and his wife themselves ate rather sparingly.

From my trouser pockets, before I had emptied them completely, I was able to impart to each of them (to old as well as young) a goodsized portion, which the grown-ups accepted with astonishment and 
the greatest amazement and the poor children with a clapping of hands and the greatest joy, and they gave thanks to God and praised the Christ child for having given them, for once in their life, enough to eat. And they fell to so mightily that it tasted good to me too, and when I saw that it was being so well used, I emptied my satchel onto the middle of the table, at which their joy was twice as great; but the roasted hare and the saddle of venison I put into the satchel to keep for myself. And since the pine knots which these people were burning instead of candles made the room, which was tiny anyway, rather warm and smokey, I was not able to wait for the end of the meal, but instead betook myself back out to the goat fodder, on which I slept till the blessed light of morning.

Now when I awoke long after sunrise, I saw that mine host was weaving baskets, while his wife and the two oldest children sat there spinning coarse oakum fibre to make sackcloth, which employment seemed to me far too unprofitable to feed ten mouths, not to mention also paying money for taxes. The woman was wearing her husband's woolen shirt, which he was wont to wear in the winter, and he a pair of twill pants covered all over with patches, and the children were all going about dressed so shabbily that I was not able to tell from these rags which they had on which ones were girls and which boys; with which clothes they also covered themselves at night, for in the room I saw the youngest daughter covered up with her clothes, sleeping in her nest made of leaves and moss. The grown-ups' bed seemed to be made of straw, which, however, was already rather well ground up. The bedstead, along with the table, chairs, and benches, were all the husband's own handiwork, and it seemed to me that he also had been the carpenter, mason, and thatcher for the whole house. The windows were of paper, and the stove in the living room was stuck together of bricks and gutter tiles. In summa summarum, everywhere there was nothing but poverty to be seen; for that reason I looked in 
my pockets also for my remaining guilder, and put it on the table as payment for the night's lodging, and went to look for a more pleasant place for myself.

On the road, and while I was walking all by myself, I contemplated how differently from one another we people in this world live, and yet was not able to discover the origin and cause of so great a difference. But when I considered that the rich had cause to struggle just as vehemently against vanity and all kinds of sensual pleasures as do the poor against impatience and the desire also to possess something, I concluded that God so ordained it so that He might crown with glory the rich man for his humility and benevolence, and the poor man for his patience and forebearance, provided, of course, that each had made himself worthy of such glory in his life on earth. And so I could not but be astonished that the day before I had frightened and perturbed the rich lady but gladdened and consoled the poor folk, when the former doubtless took me for an evil spirit, but the latter for an angel from heaven. I brooded about the reason why human judgments are generally so erroneous, and concluded that they seldom hit the mark because blind judgments, or man's perception, originate in the nature of the emotions of the inner mind; for without doubt that lady's common sense and moral sense told her that she was committing a sinful folly before the mirror, so when she by chance saw my face in it, what good could she conclude from such an apparition? The members of the poor household, on the other hand, were sighing and lamenting their troubles to God when they received help and consolation in the form of the unexpected appearance of a sovereign, and to whom, then, should they have ascribed this conferment other than to Him to Whom they were lamenting their need? Now even though both parties had come to such different conclusions about me that these conclusions could not have been any more different, nevertheless, their perception deceived them both, 
and taught me how little we ought to trust and place faith in our own opinions.

For that reason I am not surprised that old Simplicissimus put on all the etchings which are in his life story the motto Perception Deceives, 4 especially when I bear in mind that during this journey I once saved his son's life (for which reason, perhaps, he so often uttered this phrase, and chose it as his symbolum), ${ }^{5}$ namely, when a jealous cuckold accused his wife and him of having committed adultery, which tale, as I shall later tell, will bear out my above-mentioned opinion concerning the cause of the deceptiveness of human judgments. 


\section{Chapter Twelve}

Occupied with these thoughts, I must have walked for two hours before I had thought them through completely, and after I had passed through a grove of trees beyond which lay a beautiful level field, I saw a fellow walking along the edge of the woods with a cow in tow 1 which fellow betook himself onto the road where I was and which took us to E., a town of that name, which we would be able to reach in about one hour. Now before we had put more than a half hour of the road behind us, a man on horseback overtook us quite easily, because we were walking slowly. This man said "Good day" to the one with the cow and asked him whence he was coming with this cow and whither he was going with it. He answered that he was from C. and intended to drive this cow, which he had raised himself, to market in E. and to sell it there, because he was in dire need. "'Pon my word!" said the man on horseback. "Had I not today with my own eyes seen my maid milking the beast in my barn and driving it to pasture, I should have sworn this cow here was mine, so like one of my own does it look." "That I can readily believe," answered the other man, "for there is more than just one white goose." "That is true," said the man on horseback, "but my good friend, for how much would you part with her?" "Not for under twelve guilders," answered the other, "for she gives so much milk that my wife and child wept today when I drove her off, and were I not now so hard pressed, I should not let her go for even fourteen guilders." "That's too much!" answered the other. "I am confident that these days I should be able to buy a better animal for ten guilders, had I need of a cow. And were I to buy it 
from you, 'twould only be so that I might bring together two cows that look so much alike." After much discussion the sale was finally concluded for six sovereigns and four measures of wine, before we even came to the city gate.

The man on horseback did not stop at the inn, but instead stayed with one of his acquaintances, where they stabled both horse and cow and had the first of the four measures of wine fetched. I tagged along after them, for after all, I too had been a witness to the sale, and guessed from the fact that they welcomed the man on horseback so warmly that there might be quite a feast, especially since the contract called for four measures of wine, of which I intended to have my fair share, for after all, I too had been a witness to the sale. Now it began as I had imagined, but it did not end as I had supposed it would; for to be sure, the table was set and food brought in, and wine served too, and the seller, after he had received his six sovereigns for the cow, was urged to sit down; but he deported himself so discreetly and gratefully that he refused to do so unless he knew what he, for his part, was to contribute to the meal. Finally, upon his voluntary offer and polite request, he was permitted to go fetch a good pasty for the repast, for which purpose the master of the house gave him a pewter platter. At this I thought to myself: Oh, if only you durst let yourself be seen, how willingly would you contribute your saddle of venison, so as to properly make merry with these folk. But hardly had the seller reached the door with his platter or bowl than he changed his mind, for he came back and said: "'ods blood! 'Tis embarrassing that I should walk down the lane with the platter and then back again with the pasty." The buyer and the host agreed with what he said, and the latter lent him his cloak so that he might walk abroad all the more reputably. This he did, but he did not come back, and after they had waited for him for nigh on to half an hour, it finally began to dawn on them that something was amiss. And it 
was as they thought. And they were not deceived by appearances as were the above-mentioned lady and poor folks, but instead became aware (but too late and to their harm) that this rapscallion had stolen the buyer's cow from his pasture, and had also made off in masterful fashion with both cloak and platter.

I well saw that after this neither buyer nor host would have any appetite for food or drink; therefore I too went on my way, went to the marketplace, and there angled two half-penny rolls away from a baker and ate lunch right out in the open under the open sky, and along with the bread a hefty slice of venison, which did not taste bad at all. I was not reproved for this, save by my gullet, which, however, I satisfied in the cellar of a wineshop or innkeeper when the slut who was supposed to be minding the tap was gawking somewhere else, to hear the latest gossip from other chatterboxes of her ilk.

I now lacked for nothing save the opportunity to waste precious time, which folks call "whiling away the time," since I was too lazy to leave the city that same day. Therefore I betook myself down a lane to an inn wherein I heard a din, which lured me into it. Therein I found divers tables, occupied by folks of divers stations, but all of them commoners. Some were half drunk, others completely so, and still others were just beginning to tipple. One talked of this, another of that. And in the back, there sat with a bosom friend the very same man who that day had sold the little old cow, but he was freshly shaven, clad differently, and so changed in appearance that I should almost not have recognized him, had I not that very same day traveled with him part of the way. And when I looked at them more closely, I recognized them to be the very same two who had recently intended to murder the two studiosi.

The close counsel which they were taking with one another, their foxy eyes darting here and there as other scoundrels' do, and also the fact that I had already learned-indeed, had seen with my own 
eyes-that the cowtrader was an arch-rogue, caused me to sit down with these fine fellows, to hear whereof they were treating with one another. Moreover, I had already become incredibly curious anyway to learn, without being seen, other folks' secret conversations and plots, in order to take delight in them, because save for this, I was not able to enjoy any amusement and diversion, or to have any other fun.

Their plan was "to call on a rich 'un the next night and prig 'im," or, in plain English, to break into and enter the house of a well-to-do man and rob him. Oho! I thought. You must go along too. Not that I should have wished to be partner to their thievery, but rather to throw their compass off, since it seemed to me that their plot, as they proposed it, veered far too far from the code of the thieves' guild (of which, in respect to getting my food, I was at that time a member myself) and too close to that of murderers, for they said: "The master of the house is himself sick abed with podagra. Tomorrow his wife must needs go to her sister's wedding, and she'll stay out at least till midnight. The clerk or the servant-maid, one of the two, will be obliged to light the mistress' way with a lantern. Therefore there will be only the sick podograst ${ }^{2}$ and one other person in the house, and should one, or even both of them, awaken during our labors, how easy it will be to strangle them." Therefore I remained with those two fellows, with the intention not to stray from their heels till I had first tripped them up, even though in their company I was obliged to forego my heart's desire and suffer thirst, or (to express myself more fluidly) was unable to get a drop of wine to drink. Finally one of them named the house which they planned to rob by mentioning the sign which hung on it, and so I left them to find it and to stand salva guardia 3 there and protect it from them.

When I found it, I went inside and saw that it was sufficiently well stuffed and provided with everything which a wealthy house ought to have in it. The storeroom contained all manner of wares, 
in such superabundance that one might easily measure the owner's wealth by them. In a side-vault I found a cask of that noble drink, Peter Simon, ${ }^{4}$ which I tapped while the clerk was busy elsewhere, handing out wares to several customers, with which drink I heartily refreshed myself, and which I did not spare at all, because, after all, I planned to properly earn it on the appointed night. And it tasted so good that I took a glass bottle and, since I had sufficient time, filled it full and took it with me upstairs to the attic of the house, where I had an elegant evening meal of my venison and, fairly well drunk, settled myself comfortably on some canvas wagoncovers which were lying there.

The following morning I did not awaken till about eight o'clock, and because I still had some of Peter Simon left over, and also an appetite, I first of all breakfasted, then sneaked about in the house, and came to the upper chamber where the master of the house lay ill with podagra, while his wife, a beautiful young woman, stood there before the mirror and primped for the wedding. She was wearing gorgeous clothes, and was not badly bedecked and adorned with belts, rings, pearls, and that sort of jewelry, for which reason her lord and master, despite his podagra, was enflamed with such violent desires that he expressed the wish that she, in all her finery, joust with him a bit, in return for which he, for his part, would gratify any of her wishes, whatever they might be. The wife did not balk at this for long, but so that she might heed and obey her husband, and be quite undisturbed while fulfilling this so pleasant responsibility, she locked the door to the room, so that I was obliged, against my will, to remain in the room and see what the podagric was capable of doing. Alas, I thought, you dear people, were you to know what murderous trap has been laid for you, and is about to be sprung, the prickings of your flesh would surely abate. After the task was completed, the wife straightened out her dress again, put on another ruff around 
her neck, and got ready to go to the wedding. The husband, however, who had now received sufficient contentament, desired to hear from his wife what recompense for her compliance she had in mind, for he was ready to keep his promise and satisfy her wishes forthwith. "Tis a bargain!" answered the wife. "My desire is that you should do it to me once more while the door is still locked." "But," said the husband, "right now is an inopportune time for me." "Aha!" answered the wife. "I well see that you too are one of those men who promise more than they intend to deliver. It was an inopportune time for me too; and nevertheless I acceded to your desires; but henceforth I'll know how much faith to put in your promises." Finally it all ended in amiable jesting, and when the wife opened the door again and went off to the wedding, I too went my way, to see the bridal procession and the other nuptial ceremonies.

Not only did I do this, but I also went into the house wherein the wedding guests were dining, since my stomach was demanding something warm of me, which I obtained for it in the kitchen. Afterwards I strolled about in the market square for a while, in order to hear what news there was, and heard from the people not only what had happened with the cow, the cloak, and the pewter platter, but also that on that same night a bale of woolen cloth had been purloined from some drapers, from which I suspected that the cowthief had helped steal that too.

Now when toward evening it was time to eat, I betook myself again to my former quarters and found the clerk transferring the daily entries into the account ledger and the maid preparing her master's evening repast, which was a bit of lettuce, a bit of barley soup, a little dash of spinach, asparagus in lemon and butter sauce, and a young roast chicken. I went along to the upper chamber and saw that the master of the house was eating while sitting up in the same bed in which that forenoon, while lying down, he had acquitted himself so 
gallantly. His drink was well-aged bock beer from Striegau, ${ }^{5}$ which is said to be very healthful. But I did not wish to sponge off him, but instead turned my thoughts to Signor Peter Simon, who seemed to me to be grander than Madame Petesina; 6 therefore I went back downstairs to see whether I might be granted an audience with the aforementioned Signor. That was very easy, for at this time the maid or cook, together with the clerk, was likewise dispatching a salad, a dried tongue of beef, a piece of jellied meat, and a small measure of old wine, along with a portion of Dutch cheese and butter.

These two, to my way of thinking, were friendlier toward one another that evening than their master and mistress had been that morning, for they let me see a little sample of their skill, just as if I had been appointed to judge whether they or their betters were best at it; and I believe, had I been asked about it, I should have given the prize not to the master but to the servant.

Now when the master had put out his light and the clerk had also gone to bed, and the maid, with a lantern, to fetch her mistress, I stood guard in what I deemed to be the center of the house, and in fact, right in front of the master bedroom, so as to hear all the better, and to be quickly close at hand, no matter where the thieves might break in. I was not obliged to wait for long either, for just when everyone had fallen asleep, and when it was almost time for the mistress and maid to return home, I heard at the back of the house, where it bordered on the garden and yard, a scraping noise when the burglars set a short ladder on a pile of firewood and leaned it against a window which would otherwise have been high above the ground, by which means they got into the house as easily as if it had been the way they entered it every day. And they had thought everything out so carefully and had talked over beforehand how they intended to do it, that I was astonished at their cunning; for while the one deposited a pile of excrement ${ }^{7}$ right there, the other went downstairs and opened the 
front door, so that if perchance someone in the house, contrary to their expectations, were to awaken, they themselves might be able to beat a retreat through it in good time. This second one brought, I know not whence, a light with him, and when he came back upstairs with it to his comrade (from whose side I had not budged) and pulled out his magic paraphernalia, with which to put a spell on the people in the house, so that none of them might awaken from their sleep, I let him go ahead and light the thing, but, straightway he had done it, gave him such a push that he tumbled down the stairs and made such a racket that I thought he might have broken every bone in his body. Thereupon his comrade went closer to the head of the stairs, doubtless to ask what had happened to him, but he had no need to ask such a question, for I straightway showed him how to take the same jump which the other one had taken, in such a manner that in this case he knew without asking as much as his partner, save for the fact that his partner had broken his leg and his back, whereas he had broken nothing. It was gratifying to hear each one say to the other: "Ah, brother, what is going on here?"

The healthy or ambulatory one straightway got to his feet again and admonished the sick one to follow him so that they might finish the job which they had undertaken, but while his spirit was willing, his flesh was weak, for as soon as he moved but a little he screamed loudly, in violation of all thieves' conventions, so that his comrade wished I know not what sort of good things down upon his head. He would have liked to carry or drag him off, but the sick man was able to suffer neither, because of the violent pain. Therefore the other one said to him: "Brother, I well see what is going to happen. You are going to stay here and bring both me and yourself onto the wheel." "No," answered the first one, "I can keep my mouth shut. Just leave me lie." "You son of a bitch!" said the other one. "If you can't even keep your trap shut when I wish to carry you away to freedom and 
save your life, what might you not do, were you captured and asked under torture about our doings?" Thereupon he in a trice grabbed him by the throat so that he was not able to continue to scream, and with a dagger dealt him twenty stabs in the chest, which I should have gladly prevented, had I been able to reach them. And when he was finished with him, he climbed back up the stairs toward where I was, I knew not whether to fetch the magic paraphernalia which had been lit, or to rob the house as originally planned; but as soon as he came near me I pushed him backward down the stairs again, so that I could not but believe that he would remain lying alongside his comrade and must needs keep him company in death as he had in life; but he was like a cat, which, even if it is dropped from a great height, will get up unhurt, for he got up from his partner's dead body and said to himself: "I'm going up these stairs, even if the devil and his grandmother try to stop me!" Thereupon I answered him: “And if I get my hands on you once more, I'll break your neck," at which the fellow was so affrighted, particularly since he did not see anyone and yet heard my threatening voice so close to him, that for the nonce he completely lost interest in climbing the stairs, for he left his magic flame, which was still burning upstairs where I was, and ran out the front door as if the devil were after him.

The door I slammed shut behind him, climbed back upstairs to the attic, and laid down on my wagoncovers, on which I had reposed so excellently well the night before. But nevertheless, I was not able to go to sleep because my conscience was torturing me for being the cause that a man had died without repenting of his sins and therefore, as must be feared, must needs suffer eternal damnation. But I consoled myself somewhat with the thought that by this deed the master of the house and the clerk had been saved, whom those two monsters might perchance have murdered in their sleep, and perhaps the mistress and the maid also, had they come home earlier. 
It was already after midnight when the aforementioned wife was accompanied home from the wedding by several of her relatives; the maid unlocked the door while the wife's friends were taking leave of her, and also locked it again after they were gone and her mistress was in the house; but when she came upon the body of the murdered murderer and saw him lying dead in his own blood, she let out a loud scream. And how frightened the mistress herself was I cannot say, for at the time I was lying in the upper story and heard how the door was opened again and the mistress' escort called back; now they too beheld the horrible sight with astonishment, and also, after they had come upstairs, the blue magic sleep-flame with wonderment. Mistress and friends went into all nooks and crannies of the house and found everything in good order and untouched. They even searched upstairs where I was lying and even higher up, as well as downstairs in the cellar and in all the vaults. The husband and clerk could not be roused from their sleep, despite the fact that they opened their eyes and said some odd things, as sometimes dreamers are wont to do. Finally it was decided to send for the magistrate, then one explanation and another were suggested, but none hit the mark; two constables or beadles were obliged to remove the body. Then they all heard the clinking of the skeleton keys which were found on him, together with concealed weapons consisting of long sharp knives.

Therefore they sent for the hangman, ${ }^{8}$ who searched through his clothes and found on him various articles which attested to the evil nature of the deceased. The hangman also recognized the magic sleep-flame, which hitherto no one had dared make so bold as to touch; as soon as he extinguished it, both the master and his servant awoke and were surprised that such a crowd of people, particularly the magistrate with hangman and town constables, were gathered in the house. And because also the ladder leaning against the house was then found, and all signs attested that the deceased (God knows 
who might have killed him) must needs have been an arch-thief, the body was consigned to the hangman, to dispose of and bury under the gallows the following day. Amidst all these strange goings-on, I walked about among the people present and might best have been able to solve this mystery, so that they should not have been obliged to cudgel their brains any further about this incident, but like a prudent fellow I kept silent, because I was not itching for any trouble. I simply thought to myself: You have done your part, and earned not only the Peter Simon which you drank, but actually quite a bit more; but what do you care about a reward which, to be sure, you well deserve, but which you can demand only with danger to your person? Were you to reveal yourself, then they would believe that you were the dead man's accomplice, and also your comrade's murderer. In the meantime it had already begun to grow light; therefore I seized the opportunity and one last time attacked the barrel filled with the drink I loved so dearly, drank instead of my brandy as much of it as I was confident I was able to tolerate and still stay sober without being obliged to soften a Hamburg zwieback in it, ${ }^{9}$ and with that walked out of the house and on that same morning out of the town as well. 



\section{Chapter Thirteen}

I turned to the right toward the Polish border, with the idea in mind of filching from a rich Jew of that kingdom as many ducats as I should be able to carry, for I was beginning to become so conscientious that I by no means wished to steal from any Christian, unless he were worse than a Jew, ${ }^{1}$ which sort of Christian, however, I did not believe I should find anywhere, even were I to go to the ends of the earth. That same day it began to rain, and therefore it was not the best time for me to be traveling, but I stomped on for some four miles, and thereby lost the heel from one shoe, which made it very difficult for me to walk, and yet compelled me to keep on walking till I had reached a town somewhere, where I might exchange my shoes, because I did not wish to permit myself to be seen in order to have a new heel put on, which village cobblers are not able to do very well anyway.

But when the heavy rain did not let up, I spend the night in a sheepcote $^{2}$ where the shepherd had just slaughtered a fat lamb for his wife to parboil and roast. It seemed downright comical to me when he held a roasted hindquarter under his wife's nose and said: "Ah, taste that! How good this thing smells! And yet, I know that if our master were to taste it, the lovely aroma would cut him to the quick; and just for that reason it is fitting that we do not rub his nose in it, so that he may not sin by falling into anger." They were quite merry during the meal, even though they, unfortunately, had naught but water to drink with it. I made shift with them for about two days, because, firstly, I was not able to go any further because of the rain, 
and, secondly, because of the swollen rivers, and during that time saw enough so that with good reason I can accuse honest Colerum of not having rooted out by far all of the scoundrelous and thievish tricks of shepherds, even though he recounts rather many of them in his Oeconomia. ${ }^{3}$

But when the sky cleared once more and pulled its black blanket from in front of the countenance of the great light of the world so that its eye might shine upon me once more, ${ }^{4}$ I set out on my way and kept to my course, always heading toward the Polish border. My saddle of venison gradually began to grow small, and therefore I was obliged to consider stocking my satchel anew with provender again. From the countrymen in the villages, however, there was nothing as tasty as this for me to get; but in an inn where I went because of my thirst, I was attracted by a delicious ham, which I fished out of a kettle hanging over the fire, and in exchange for it I put my shoe without the heel into it, 5 so that I might not get my food completely for free. But for the people in the house it would have been more bearable, but not more beneficial for their moral progress, had I simply taken the ham and not made the exchange; for even though at first they took the shoe to be the ham which had boiled away till only the rind was left, afterwards the miracle frightened them all the more, when they saw that it was a leather shoe made by human hands, and not the leather of the ham. "Oh, my dear children!" cried the innkeeper. "Don't cut the strong beer with the weak anymore! And henceforth leave the good brandy undiluted, and do not write up more on the slate than you have served the guests; for because of such transformations the ham too has been transformed, as a sign that if we do not cease and desist from our usual transformings, henceforth our food may be transformed in the way which you see with your very own eyes, and to which this unheard-of miracle attests." 
Thereupon he carried the shoe to the table, beat his breast and begged with tear-filled eyes and heart-rending sighs for mercy and forgiveness for all of his misdeeds, together with many vows and promises to reform and to give to the poor everything which heretofore he had swindled and gulled from his neighbors through the one or other transformation or adulteration; indeed, he and his family showed such repentance and their sorrow was so great that it compelled me to pity them, as it were. I thought to myself: Oh! How God's boundless mercy will be moved by all this! I rejoiced that as a consequence of my thievish prank he had come to such repentance and self-knowledge; but both the pity and the joy which I felt moved me to put down the ham again and to take up my shoe, at which in the whole house sighs of sorrow changed into cries of joy, and the woeful sobs into songs of praise for God; and thereupon I thought to myself that on that day I had performed a good work.

But just as I had not stolen the ham for any such noble purpose, and therefore cannot lay claim to any deserved reward, I also do not know whether the innkeeper and his family remained constant in their good resolve or not.

Be that as it may, because of this incident I grew so mindful of God that I did not steal either food or drink from the innkeeper that evening. I made do with small beer, which in this house was not supposed to be mixed with the strong beer and given to the guests any more anyway; and as I was devouring some of my saddle of venison, I remembered with a heavy heart that I had stolen it too, and had I not taken it from a place of superabundance, from a cornucopia as it were, I should not have eaten anything at all that night. At that time I truly learned what the society of righteous or evil people can do. But because we are generally wont to be inclined to evil (for I can tell by my pears when others' are ripe), at that time I took these thoughts so little to heart that I was able to sleep quite peacefully that night. 
Early the following morning my main concern was where I might get new shoes and again some provisions to eat; and when (because of my recollection of the beautiful example which I had seen in the innkeeper's conversion the evening before) I reflected that both of the things I was in need of must needs be obtained by sinning against the seventh commandment, I began to recognize that the mode of my life at that time was reprehensible. On top of that, this mode of life seemed very irksome to me because of all manner of other inconveniences which I was suffering. I saw that neither a clear conscience nor a good accommodation was suitable to and consonant with it, for although I was invisible to the eyes of human beings and animals, nevertheless the lice, of which I myself bred a considerable quantity, still found me, because I never got out of my clothes; and I also saw that if I continued this way, and as a result fell ill, I needs must perish in body and soul, without aid and consolation from any human being. I further reflected that God and Nature had produced and created such a wealth of strange powers and wondrous effects that among them perhaps one might be found (or even indeed some artist or other) which or who might be able to withstand the workings of my bird's nest, destroy its power, and thus make me visible and thereby deliver me into the hands of the magistrate, who, because of such palpable evidence and rarely seen disguise, would have good cause to put me on the rack and have me tortured till I, despite my innocence, should confess so much that they would send me, as a sorcerer, from the funeral pyre to heaven in a cloud of smoke, as they had the former owner of my bird's nest.

These and yet many other worrisome thoughts of that sort caused me, contrary to my usual custom, to tarry idly abed a full two hours longer than was otherwise my wont, even though I was only lying on straw in a stable; but I made no firm decision one way or another, but 
rather decided to ponder the matter further, which I did when I set out on my way. 



\section{Chapter Fourteen}

I very much yearned for a city in order to get new shoes, but instead came to an imposing monastery and the village by it, which, because of its size, I took from afar to be a rather large town. Now when I came through the village up to the monastery, I found the little door open which an old fellow with a pegleg was watching, so that no stranger might enter the monastery unannounced; he was making nets for either fish or birds, and himself had also as an overseer a member of the order sitting in a room situated directly inside the gate, which person was mending shoes, because by trade he was a shoemaker, and for this reason had been admitted to the order, not only to make shoes for large and small, but also as superior officer over the man with the pegleg in guarding the gate. For that reason I took him to be just the man I was looking for, namely, someone who would shoe me anew as my needs required. I should have gone through the gate, even though the devil himself had been keeping watch for them. Over the door of the above-mentioned person was written in Roman letters "St. Crispinus," from which, in fact, I remarked what sort of work they did there; for otherwise I should have gone on past it, and should not even have paid heed to the fact that this was the very place where I might be able to find help.

Well, I entered at an opportune moment and found, to be sure, many lasts and quite a bit of leather of all kinds: $a$ la mode and country style, common and ordinary, Cordovan, greased, Prussian, Polish, Hungarian, Dutch, white, red, yellow, and, in summa, all kinds of leather, but nevertheless not a single pair of new shoes or boots 
for which I might have exchanged my own; and what was worst of all, the good laicus was mending old shoes, of which he had there a whole flour sack full which were already finished, and just as many which he still must needs mend. Now even though I saw no chance to exchange my shoes in this place for better ones, I nevertheless thought to myself: This fellow surely does not have so much splendid leather here for making shoes for old ladies to live in ${ }^{2}$ and for mending shoes. Therefore I thought about the matter further, and thereby the idea occurred to me that the monastery must needs have stored somewhere a quantity of shoes, of which perchance one particular pair might suit and fit me; these I undertook to sniff out, even if I should have been obliged to tarry in the monastery for seventeen weeks. ${ }^{3}$ About food and drink, and how I might get them while I was there, I was no longer worried, for I saw so much that I had no cause to wish myself at the Court of King Arthur, where adventurous knights errant of the Round Table were always so well fed.

I went on through the outer and the inner courtyard, and found yet more workshops of other artisans, such as smiths, bakers, butchers, potters, cooks, and the like, which were likewise occupied by lay brothers of that same order. I came to a stable wherein were standing the most beautiful saddle- and draft-horses; the cattle, sheep, and swine were of course out to pasture, but from the stalls I well saw that there were a large number of all of them there. I also came to the mill, which, however, was entrusted, as was the care and feeding of the cattle, not to members of the order but rather to secular persons. From there I came to the orchard, the kitchen garden, and the flower garden, which were truly a joy to behold, because everything was arranged and tended in such an orderly and almost princely fashion; and for just this reason the inquisitiveness of my eyes, which were feasting on them with such great delight, caused me to stroll about them longer than I had actually intended. 
Sneaking hither and thither, I came into a natural bower in which there were some benches and a stone table, at which two patres were saying their horas. 4 When they were finished with their devotions, the prior said to the chief cellarer 5 that His Magnificence had been apprised of how he, the chief cellarer, had sat the night before last in the servants' hall till one or two o'clock in the morning, had amused himself with the shepherd's shawm, and in so doing had at the same time treated some of the servants to quite a lot of beer, which displeased him, His Magnificence, greatly, for which reason he had commanded him, the prior, to conduct an inquiry and, after determining the facts, to report back to him what had happened, so that, in order to prevent such abuses in the future, he might be able to proceed with the exactment of an appropriate punishment, and thus might be able to prevent all further indecent affronts which might be offensive to the laity, as well as also unnecessary prodigality. The chief cellarer answered: "'Tis true that I was enjoying myself there, but what is that compared to the great effort with which I am continually burdened in the business of the Church? A ram butts all the harder when he backs up a bit and takes a running start; and anyway, I did not kick over the traces all that much. The shepherd would have slight advantage over his flock if he were compelled to eat grass like his cattle; and I also cannot agree that it is a great wrong if one now and again allow those who deserve it because of their faithful industry on behalf of the Church to have a hefty little drink, since that way one lures and spurs them on to commensurate industriousness. But I should indeed like to know who the toady was who carried tales to His Magnificence." "That," said the prior, "Your Reverence can figure out for himself." "I'd bet my life," answered the chief cellarer, "that young Simplex did it, for I have let the others who were there have as much to drink, and even more, which persons, however, have always kept silent about it." "I believe you're right," said the prior, "for had 
he not at some time or other carried some tale of that sort to him, then it would be impossible for him to have so quickly grown so dear to His Magnificence's heart. He loves him more than ever a king did his favorite! And if we allow him to continue this way, in the end not one of us will be able to so much as let a fart without his telling His Magnificence about it, so that in the end we must needs fear him more than His Magnificence (just as game fears the bloodhound more than the hunter)." "Therefore," answered the chief cellarer, "it is necessary that we rid ourselves of this Battum6 betimes. But in what way this may be accomplished with impunity remains to be considered, because it will be difficult to bring about, since His Magnificence loves him so dearly. 'Tis indeed true, the young man has fine qualities; but his great shortcoming, perhaps inherited from his father, is that the fantast is so completely forthright and is unable to either simulate or dissimulate, nor is his honest German tongue able to keep anything secret, but is rather in the habit of bluntly and without hesitation telling everyone the truth. This shortcoming will ruin him and in the future might cause us much distress. However, I have a plan whereby he may be unhorsed. That I wish to try. If it works, well and good; if it does not, then we must think of something else." While these two were thus conversing with one another, I became aware that beside the one pater lay a handkerchief, a pocketknife, a snuffbox, and a key, which he had taken out when he was looking for a missive. I directly recognized the key to be the master key, because it was filigreed with manifold curlicues and raised bands, and otherwise intricately designed, and therefore I took it, because it was the most suitable instrument by means of which I might get at the shoes I desired, and I was not deceived either.

Thereupon I went out of the garden into the building, and sneaked through all the rooms and nooks and crannies of the entire monastery; wherever a door was locked, I opened it with the master 
key; I found the library, special rooms in which to study, special ones in which to recreate oneself, special ones in which to eat daily and ordinari meals, and also special ones in which to dine extraordinari with guests from outside, special rooms, cells, or small chambers in which members of the order lived, and very special ones which were accommodé for strangers and guests. I also found the bath, the bakery, the larder, and, what pleased me most, not only the stores of new shoes and boots, old and new saddles, and other tack, but also a large supply of all sorts of linens, shirts, tablecloths, hand towels, napkins, handkerchiefs, stockings, collars, and the like, of which those which were freshly laundered lay in neat piles, whereas the dirty ones were hung over some poles. There I exchanged my dirty shirt for two clean ones, and was not obliged to give more in return than the lice which were in my shirt in countless numbers; and in the same manner I gave up my shoes for a pair of new ones which fit me as snugly as if they had been made to measure for me; indeed, I liked them so much that I should not have taken any others but them, even if I needs must have paid for them in cash.

After outfitting myself this way, I had no other tasks that day, save to fill my stomach and to betake myself to my lodging. The first I did in the bakery, and also enjoyed a good mug of well-aged strong beer which I happened upon by accident and emptied to the health of the baker, in his absence, while devouring completely the rest of my venison; the second I did straightway thereafter in a cell in which, to all appearances and to my way of thinking, a bed had been prepared for strangers, which bed suited me so excellently that I slept in it without a care in the world till, the next morning, everyone in the monastery had spent his allotted time at the church; I made up the bed again, as is proper, and arrived in time for the last mass, which that day had been delayed and held up for a person of high nobility who had come to visit the prelate and to perform his devotions there. 
They had made conspicuous preparations for the gentleman and did him all honor as a benefactor and dear neighbor of this church. He dined with the abbot at his table, whereupon I mingled with the waiters and helped myself to morsels from the plates and bowls which had been removed from the table. Now there I saw young Simplicissimus helping to serve the meal, and also, sitting at the table, the two patres who wished him ill. He was a handsome young person, indeed as well formed and delicate and as pleasing in his manners as any man I have ever seen, so much so that he inspired in the guest of honor such admiration that he asked the prelate in his, young Simplicii, absence, whence this lively fellow had come to him. The prelate answered that he was the world-famous Simplicissimi son, whom his father had recommended as chamberlain, that besides that he was studying at the university, and was being looked over to see whether he might not be suited to the clerical estate; and with that he sang his praises in such a manner that one was able to tell without difficulty by how far his knowledge and his gifts of mind surpassed his physical beauty. In short, in the eyes and judicio of the prelate he was of such high repute and estime that had the pope thought so highly of him, he must needs have straightway been made a cardinal.

I well remarked that this praise was heard by the above-mentioned patribus with resentful ears, for which reason one of them said: "Tis to be hoped that he is as pure in every way as he is believed to be; 'tis indeed true, he has incomparable qualities, but...!" And with that he fell silent, leaving His Magnificence time to ponder his words. But after the meal was over, he further reported, at the behest of His Magnificence, how some coins from the collection plate had been snitched from a place to which no one had access save Simplicius. "I shall test and examine him myself," the prelate thereupon answered, "which can be done with a single Louis d'or, which I shall place in my room where he can see it." I thought to myself: And then 
the innocence of the accused will surely be demonstrated. But what did happen? No more than a few days later I heard one of the two malevolent ones say: "The die is cast! I got my hands on the sovereign left as bait, and today His Magnificence will get rid of our bloodhound." What I thought to myself the reader can well imagine. With that he pulled out the Louis d'or and said: "What shall we do with it, for it is blood money?" But while they were taking counsel with one another, and had scarcely laid it down, I snatched it up, so that it disappeared before their very eyes, to their extreme consternation.

I straightway went to put it back in the room of His Magnificence, so that I might yet perchance save the innocent young man; but before I was able to get there, young Simplex had already been dismissed, under the pretext that the Church already had a sufficient number of people; and then I did indeed begrudge the monastery the sovereign too, because he who had been chased away because of it was no longer a member of the monastery either. Hereupon I remained almost a full week in the monastery and observed the usages, organization, and customs of the order. I saw the most pious persons, who lived in their service to God almost like angels, but on the other hand I also saw some people who clung too much to things temporal. Artlessness fared best there, and those who were possessed of it seemed to me to be the most pious; the clever, however, were burdened down so heavily with the affairs of the world that it seemed to me that they were living in as great peril to their eternal salvation as were the people of the secular world. For the rest, I should have indeed deemed and considered this monastery to be a blessed place, had only dismal envy and ill will not dwelt there also. From everything which I otherwise saw, there seemed to me to be there a sufficiency and superabundance, also such a moderate and well regulated order, that I should not have wished for any better 
life; but the above-mentioned hidden pestilence kept itself so well concealed that it could not be cured.

Now after I had rested sufficiently, and also fattened myself up again, I equipped myself from the kitchen with a ham and a leg of mutton seasoned with garlic, because I knew that they do not taste bad when eaten cold. I returned to the cellarer the master key, which I had kept till then, without saying "Thank you," and thereupon continued on my way; and I should have gladly expressed my thanks for the excellent treatment I had received, had I only been able to figure out in what way this could be done fittingly. 


\section{Chapter Fifteen}

I walked for about two hours without encountering anything memorable, but when I sat down right by the side of the road next to a well to eat my noonday meal, up came that same cowthief whom I had already met several times before on the road, namely, the one who had executed his own comrade in the merchant's house. He sat down alongside of me in the shade, pulled out a piece of bread and meat, and began to eat apace with me; and when he had satisfied his hunger and started on his way again, I wandered along with him, so that if perchance he again wished to engage in some evil doing, I might be able to prevent it; but we came upon nothing on which he ventured to lay violent hands, but rather, after three hours, we arrived in a city in which there was a university, where he entered a tailor's house and asked whether his coat were finished. The tailor, to be sure, answered "No," but did say that only the buttons remained to be sewn on, and if he were willing to be patient for just half an hour, he should be properly taken care of. The fellow was satisfied with that, but before the half hour had passed the bailiffs and beadles from the city came with several armed men and took Master Urian ${ }^{1}$ to gaol. For the drapers from whom several bales of cloth had recently been stolen in the neighborhood, at a country fair, had made arrangements here and there both with other drapers and with tailors by means of which they might trace their lost property. Now since this footpad had engaged to have a coat made of two colors, namely purple and blue, and had instructed the tailor to sew it in such a fashion that one might turn it inside out and wear it with the one or the other color 
showing, this seemed suspicious to the tailor, so that he reported it to his magistrate (as all members of his trade are required by oath to do), especially since the drapers also recognized both pieces of cloth as part of their goods. And thus was the thief betrayed and caught and, following that, hanged; but his body, together with its chains and clothes, was stolen from the gallows on Good Friday of the following year. ${ }^{2}$

Now after the beadles had led him away, I went into an inn with a ram's horn hanging in front of it, in the hope that there a little sip of wine or beer might come my way; but no guests were there at all, so that I despaired of quenching my thirst there. I had come into the room with a millwright, who carried a sack of flour and put it on the bench; the innkeeper's wife, who was there alone, gave him a piece of bread with a slab of stinking soft cheese on it, and went and fetched him a quart glass full of wine. While she was out doing that, the miller laid the soft cheese on the sack which he had brought, either because he did not eat cheese, or because the natural odor of the cheese was simply too strong; after that he drank the wine, said "Thank you!" and received from the innkeeper's wife the order that if he should, in the future, be equally careful of her property, he should now and again not lack for a drink, and perhaps sometimes even a gratuity, according to how well he did his job.

When the millwright went out, young Simplicius came in and ordered a half measure, which the innkeeper's wife forthwith fetched for him. He sat down with it, while the innkeeper's wife fetched the kneading trough, put it by the parlor stove, and prepared to mix the dough. But when she was unable to carry the sack of flour over to the kneading trough to empty it therein-even though she wore herself out trying to, so that she smeared the cheese which was lying thereon all over her neckerchief, soiling herself without knowing it-honest Simplicius stood up and, not wishing to permit the innkeeper's wife 
to exhaust herself any further, took the sack (despite the fact that he got flour all over his clean clothes), carried it to the kneading trough, and emptied it; and as both he and the innkeeper's wife were slapping their clothes in order to dust themselves off, the innkeeper himself came into the room and straightway at first glance grew pale when he saw such a handsome young fellow at such work with his likewise not unattractive young wife; in summa, he was so mortified that at first he was not able to say a word. But as soon as he saw on the breast of each of them a bit of the stinking cheese, which appeared to have been rubbed in, and also that the whole room was full of its smell, because of this, as he thought, certain and indisputable evidence, he could restrain himself no longer from calling his wife an adulterous whore and wanton slattern, and Simplicium an adulterous whoremonger, scoundrel, and traducer.

He took no time to listen to the excuses of either his wife or of Simplicii, but rather, in his (as he assumed) righteous anger and raging zeal, grabbed chairs and benches, to execute both the innocent adulterer and adulteress. Young Simplex, to be sure, went en garde as best he could, but against such an enraged innkeeper, intent only on revenge, he should have accomplished little, had not I, who was invisible, hindered the irate innkeeper from landing his cruel blows. This alarm was straightway heard in the neighborhood, and therefore all the neighbors came running in; and when, to the good fortune of all, the bailiffs and beadles, who had just taken the aforementioned footpad to the tower, came by, they too straightway rushed into the house, and by the authority vested in them put under arrest the innkeeper, his wife, and Simplicium, without anyone giving a thought to the sack smeared with cheese which had been the cause of this strange and unforeseen spectacle.

Now when I saw that in this inn there would not be anything to gulp down, I went in search of another one, and at the end of a long 
lane came to one which had antlers over the door, and was therefore called the Buckhorn Inn.

Just as I arrived, an old graybeard was dismounting who, with his beard and clothing, reminded me of antiquity itself; the servant led his horse to the stable, the old man, however, marched into the taproom, and I went in with him; there the innkeeper was sitting and reading in two books at the same time, because he had just as few guests to wait on as the innkeeper at the Ram's Horn. "God be wi' you," said the old man to the innkeeper, "God be wi' you, Master Cheatum, ${ }^{3}$ wherefore so engaged in double devotion? Surely you are thinking that since you charge double, you must also pray double!" "Aha!" answered the innkeeper. "Welcome, my so righteous, honest Master Simplex! Whence do you come so unexpectedly? I was afraid you were dead, since I had not seen you for so long." "Alas," answered the old man, "I should not be here now, had my son's affairs not forced me to come here. I recently recommended him to the prelate at N., ${ }^{4}$ in the hope that among clerics he too might be inclined toward a clerical career and enter into the perpetual service of God; but now, a few days ago, he wrote to me that he had been dismissed from there again, he knew not why. At that I was very surprised, and therefore looked at his horoscope 5 and found that at this time, but particularly today, because of envy, error, and mistrust, he will be in most extreme peril to life and limb because of his uprightness and inclination to be of service to everyone; therefore I made reply to him and commanded him to appear on this day, here in this house, and to await me here, to see how he might perchance be helped. But tell me, sir, while I am waiting for him, what are the books there in which you are reading at the same time? Is that smallest one perhaps Thomas à Kempis?"6 "Indeed not!" answered Cheatum. "I've not yet made the acquaintance of that Thomas. This is Asenath, and that one Chaste Joseph; 7 these two I am reading and comparing with one 
another because Asenath and Joseph are said to have been man and wife, 8 and I see where the author of the more recent one is dealing cuffs aplenty to the author of the earlier one. 9 I am doing this more to pass the time, because just now I have no guests, than to pronounce judgment in favor of the one or the other."

"Joseph?" said the old man. "Yes," answered Cheatum, "and Asenath, which really does not contain much more than Joseph does, save that the author makes her very nearly a nun and gives her a different father than did Greifnsohn, who described Joseph's life." "My, my!" said old Simplex, "but meanwhile fetch a good measure of wine, so that I do not sit here to no good purpose." The innkeeper obeyed, and while he went to fetch the wine, Simplicissimus riffled through both books. In Joseph he did not spend any time at all, but in the so-called Asenath he tarried all the longer, and in fact as long as the innkeeper was gone; but when the latter returned with the wine, put the pitcher on the table, and went to rinse a glass, Simplex, without the innkeeper's noticing it, drank down the wine in one long swallow, so smoothly that I do not believe a single drop was left.

Straightway thereafter he went back to rooting around in Asenath, and particularly in the annotationibus, still looking as thirsty as if he were waiting impatiently for the glass; but when the innkeeper came with the glass, to pour wine into it, and found nothing in the pitcher, old Simplex laughed and said: "If one were able to pour from empty pitchers, then I should indeed be an arch-fool to turn in at an inn. One pitcher which I bought would then suffice to quench my thirst all my livelong days; first go and fill the pitcher itself before you try to fill glasses from it." The innkeeper did not know whether the wine had vanished by magic, or whether he had brought no wine with him from the cellar, and therefore shook his head in wonderment and fetched another measure of wine, from which he poured some for himself and drank a most cordial welcome to his old acquaintance 
Simplicissimo, who, however, declined to drink to him in return, and gave him to understand that he had earlier quenched his thirst from the already empty pitcher, and that now Master Cheatum should do likewise from the full one. 10

Meanwhile he went on leafing through the annotations in abovementioned Asenath, and, as a matter of fact, in such careless great haste as if he were under contract to do so; and when he came to the end, he said to the innkeeper: "I well see that neighbor Simplicissimus has his Zoilum, just as did famous Homerus!11 Since The History of Asenath, 12 to which reference is made so often here, was written before this one, why then is it necessary that it be adorned, or rather disguised, like the crow of Horatti, 13 with feathers plucked, now after so many hundreds, nay, thousands of years, from my life history of Joseph? The story of Asenath, which I, to be sure, have not seen, I take to be a poem by some old rabbi, by means of which he aimed to spur the Jewish youths on to virtue and chastity, so that God, if they remained constant therein, would reward them, just as he did chaste Joseph, with an equally chaste spouse. Nor is it reprehensible if, for this reason and because of the incomparably chaste Joseph's own virtues and merits, poets invent such an excellently well-bred wife for him. But I do not like it at all that this author, on page 395, rejects my use of the name 'Imaus' and others' use of 'Conchares,' and yet another's use of 'Alrian,'14 and so forth, because this conflicts with accounts of historians which he has read about this matter, as well as with The History of Asenath and The Last Will and Testament of Joseph, 15 for he himself admits tacite that he has not read all the histories on this subject, but, following most of the ones which he did read, calls the Pharoah who reigned at the time of Joseph 'Nephrem' and also 'Tomestor.'16

"What I think about The History of Asenath I have already said, and say also that I believe exactly the same thing about The Last Wills 
and Testaments of the Twelve Patriarchs, 17 and also believe that just as it is salutary for pious Christians to take to heart the true story of the grievous suffering and death of their Saviour, so that they learn from it of the inexpressible love of God, so that their hearts are moved to respond with sacred love and due gratitude, and so that they learn from it to comprehend humility, patience, meekness, and other virtues and unbelievable treasures which this love encompasses, and to draw sustenance from it, thereby acquiring that for which they were especially created by God; so, in like fashion, the above-mentioned testaments were written by the wise Hebrew rabbis for their youth, and set up as a mirror, as it were, in which their youth might see how they should live, practice virtue, and flee vice; in which intent it made little difference to these rabbis whether or not, in the one or the other story, they transmitted and adhered strictly to historical fact.

"And also: That these two works should have been kept secret for so long because of the jealousy of the Jews, as the author claims in his preface, 18 I find hard to believe when I consider that the Hebrews kept the cabala so secret that no one was permitted to write it down before Ezra's time, but then, when Ezra put it down in writing at the command of God, not everyone was permitted to read it; and that nevertheless this same cabala became, according to Garzoni's testimony, so commonplace that it was printed in Latin at the order of Pope Sixtus IV for all to read. ${ }^{19}$ Many, indeed most Hebrews contend that Potiphar bought Joseph because of his beauty, in order to abuse him, and because of this became impotent before he was able to accomplish his sinful purpose; and this is attested to by The History of Asenath, cited by the author on page 408. Now if this were so, then The Last Will and Testament of Joseph is wrong when it expressly reports that Joseph was bought at the instigation of Potiphar's wife, as can be read in this author's work, on pages 441,442, 443, and elsewhere. 
"Nevertheless, I adhere to my firm belief that The History of Asenath, together with The Last Wills and Testaments of the Patriarchs, was composed long after Joseph's time 20 by some Jewish rabbis, more with the idea in mind of enticing the youth to emulate Joseph's virtues than of presenting them as historical fact.

Which Potiphar's son-in-law Joseph, however, became, Holy Scripture $^{21}$ and the Jewish historian Josephus ${ }^{22}$ attest with such complete clarity that no one can convince me to disagree with the opinion of St. Augustini, 23 for it behooves me anyway to give more credence to such a holy man than to those who invented The History of Asenath and Joseph's Last Will and Testament; and moreover, I agree with the learned Vossio 24 and, like him, cannot comprehend and believe that Joseph, to whom this author himself, not unwisely, assigns the ermine as a symbol,25 should so carelessly besmirch his fair skin and marry a woman whose father wished to commit sodomy and whose stepmother adultery with him-particularly at a time when he was master over Egypt, possessed great honor and wealth, and had the choice of all the ladies of the kingdom; moreover, Joseph's former master was without doubt no longer held in such high esteem (after it became known in what manner he had unjustly held the now so highly regarded Joseph a prisoner for such a long time) that Joseph, for the sake of a rich marriage portion or dowry, should have had cause to join his till now preserved chastity with a member of an unchaste breed.

"Finally, that the author expresses wonderment on page 442 and 443 that in my life history of Joseph Potiphar is reported to be a widower whose wife is named Selicha and is kin to Asenath 26 makes me wonder in turn at his wonderment, because as a well-read man he knows how the writings about this story vary; but if he also had heard how strangely and varyingly the Persians, Arabs, and others 27 tell about it orally, then he would not wonder at all at what I wrote in 
my book; moreover, these peoples, to this day, still do not use printing presses, for which reason then their hand-written exemplaria are seldom found to be in agreement; anyway, it would be going much too far, and the matter is not sufficiently important, that one charge anyone to find out for himself what various accounts these peoples have of Joseph's life history. But if you, Master Cheatum, would also like to know where I found the name 'Selicha' for Potiphar's wife, then look in The Persian Travels of the famous Olearii; 28 from which you can easily guess that I learned this name from that same nation, and did not pluck it out of thin air."

Up till now the innkeeper had listened in silence with wide-open mouth, eyes, and ears to old Simplicissimus; but now his serious demeanor changed so completely that he broke out in loud laughter, because Simplex looked so funny and had talked more than was otherwise his wont. 29 "I should not have believed," said he, "that you, Sir, would become as angry as this about something which does not concern you at all, and, contrary to your usual practice, make so many dicentes."30 "What!" answered the old man. "I am the author of Joseph, and would you like it if someone took your money, and afterwards spread the rumor that it was counterfeit? The fellow pulls out my hair, and afterwards dares to tell everyone that I have on a false periwig."

While the two were thus talking with one another, the news came that they had taken prisoner the innkeeper of Ram's Horn, together with his wife and a student, from whose description old Simplicissimus surmised that it must be his son; therefore, old Simplicissimus could stay there no longer, but instead rushed right out and went off to learn the truth, and to find out of what his aforementioned son was being accused. With him went the innkeeper, as his old acquaintance and good friend, to whom Simplex said: "What would you wager that my son saw the ram's (or buck's) horn of the Ram's 
Horn Inn and mistook it for your Buckhorn Inn, where I wrote him to meet me?"31

As soon as they were gone, I began looking for the innkeeper's writing materials, which I found in an adjoining room, and then wrote the following report on the fourth part of a sheet of paper, as simply and clearly as I knew how-namely, in the following manner:

A miller brought a sack of flour to the Ram's Horn; to him the innkeeper's wife gave a piece of cheese and bread, which he put on top of the sack, till the innkeeper's wife also brought him a drink; the cheese he left on the sack after he had drunk, and went on his way. After this came young Simplicissimus, had a half measure brought to him, and when the innkeeper's wife labored in vain to carry the sack of flour to the kneading trough, Simplicissimus, without being asked, carried it there, during which work both of them got dusty from the flour and smeared with the cheese. When the innkeeper came into the room at that point, he suspected that the two of them had committed a wrong; the miller, as well as the mute sack of flour, will attest to the truth of this, concerning which matter the former can be questioned, and the latter inspected.

With this written report I followed along after Simplicissimus; but because it was already late, so that he could neither be heard, nor accomplish anything else, save that the case was to be taken up the following morning, I went back to the inn with him again, and the following morning to the courtroom, where the case was heard and taken under consideration.

The innkeeper of the Ram's Horn was the plaintiff, and had no other proof that he was a cuckold than the rotten stinking cheese and the flour dust, which was taken even by some sensible folk to be 
sufficient evidence that the two persons accused might have come rather close together with their bodies, particularly since young Simplicissimus was a tall handsome fellow; but he, as well as the innkeeper's wife, swore before God that they were innocent. I, however, did not wish the case to be discussed back and forth, endlessly and vainly, but rather laid my written report on the table before the judge, at which everyone wondered greatly; it was read aloud by the actuarium, and thereupon both the miller and the flour sack were fetched, both of whom confirmed what I had written; hereupon the two accused were acquitted, the plaintiff, however, harshly rebuked because he had wished to make his innocent wife out to be a whore, and himself a cuckold, which, after all, no man has ever desired to be, and which is otherwise quite unheard of.

I went back with the two Simplicii to their lodgings, where the old man awaited a reply from the court of a count to whom he had recommended the services of his son; the reply, however, was not what they had hoped for, but rather as follows: "Most Highly Honored Sir: How much I should have liked to see your son in the service of my gracious Lord you, my good friend, will scarcely be able to believe; to my heartfelt joy, His Grace had firmly decided to accept him into his service, but first wished to inquire about how he had comported himself in the monastery, and why he left it again so soon; and he received such an answer as dispelled all his desire and intent to accept him into his service. I must communicate to you, dear friend, in the greatest confidence, and under the pledge of secrecy, that it was reported of him that he was wont to be loose-tongued and lightfingered. Although my gracious Lord believes neither, neither does he place great confidence in him. In the desire that God may keep and protect us all, I remain etc., etc."

This pained me greatly, and the two Simplicii even more. For it was indeed uncivil and unkind of them not to be satisfied with 
the dismissal of the young man, but also to defame him abroad and stand between him and his good fortune; but it also afforded me particular joy and delight when I saw that the two were able to reconcile themselves so well to this adversity. "What?" said the old man. "If a man does not wish to be my master, then I must not serve him either. The whole world is open to us; we may go begging in it wherever we wish. 'Long at court, long in hell,' as the saying goes, and if my son is predestined not to be a monk, then let him become a soldier. A man is a fool who hangs himself because they will not let him into prison, which is what both life at court and life in a monastery are like." 


\section{chapter sixteen}

The next day I continued on my way, and walked along with an honest peasant lad into a little town which was already in Polish territory, but where the German language was still spoken. He did not spare the shoe-leather, so that he soon caught up with a young peasant lass from his own village who was driving a shoat to market. Between the two of them a flirtatious conversation soon began, and the fellow even made so bold as to tickle her a bit about the neck, and to speak to her of an even more pleasurable matter; however, he stayed within the bounds of propriety. But just as we were now about to pass out of a little woods, the girl reminded him of what he had spoken to her about, but not done, adding that the bushes there would be suitable for this, and that no one else was around. The lad, for his part, grew red with shame and said: "You wanton baggage! Will God then not see it? Of course God will see it, and will be angered by it; and the angels will see it, and will be aggrieved by it; and the devil will see it, and will accuse us of it on Judgment Day. If only people were to see it, however, then it would merely be a matter of disgrace in this life, which you fear more than eternal damnation in the next."1

I was all the more surprised by this answer, because I should not have looked for it from such a peasant lad; indeed, it so moved my heart that I could not but heave sigh after sigh, and repeat these words to myself more than a hundred times, and the more I did, the more seriously I reflected upon them; these words taught me to look within myself, much more so than if a preacher had uttered them; they opened my eyes and permitted me to see for what reasons I 
sinned so often and frequently, namely, because I so little considered God's divine omnipresence; and although I had been told innumerable times before that I should keep God ever in mind, I had nevertheless neither rightly understood this golden rule and warning, nor considered its usefulness, much less obeyed it, as I now understood it, saw with my own eyes its usefulness, and was determined henceforth to obey it. I saw then that a person who does not always have God in mind, and in all his doings does not fear His presence, must needs be called godless, and is godless in his works.

It was all the easier for me, at that time, to comprehend this and take it to heart, since all the follies, mistakes, sins, and vices which, as long as I had had the bird's nest on my person, I had seen and heard in others would not have been planned nor ventured, much less carried out, had only those who committed them known of my invisible presence, despite the fact that I, like others, was merely a sinful mortal, and by no means a saint, much less an angel, whom it would have caused sorrow, nor a devil, who would have denounced it. I thought of that pious monk who, upon the persistent urging of a frivolous trollop, promised to commit with her the unchaste act, provided she perform it with him in the open market place, before the eyes of all the people, which woman, however, out of shame, did not wish to do so, and whose passionate fury instead changed into salubrious conversion. ${ }^{2}$

Oh Lord! I thought to myself. Shall a weak wench, a wench who is plagued by her amorous passion, and spurred on by the burning desires of lust, a wench who is infected with this almost invisible sickness of love, and (as nearly all lovers are wont to be) is thereby bereft, as it were, of all her senses and of the proper use of reasonshall she be deterred from sinning by the presence of people, while the rest of us, who deem ourselves better than wanton whores, do not shy away from committing the most odious vices in God's presence! 
Before your fellow man, who may perhaps be a sinner like you, you are ashamed; but before Him, Whom you anger by sinning, Who watches, hears, and will reward or punish you according to your merits, you are not ashamed.

Oh, what great, pitiable blindness! Oh, what irresponsible, stubborn folly of men who do not forbear to sin when only their Creator sees it, but who are quick to break off their sinning when mere mortals see it! By this do you not honor man more highly than God? By this do you not put the creature before its Creator? By this are you not in truth naught but an idolater? Oh, if only we mortals, we Christians, were to do what wise Seneca says in his Hercule furioso, when he writes:

\section{Sequitur nocentes victor a tergo DEUS. ${ }^{3}$ \\ That is: \\ Beware! Beware! Lord God is near! \\ He's watching you, He's always here.}

If only we would obey the holy Apostle, who so earnestly admonishes us to conduct ourselves as in the day, ${ }^{4}$ that is, to accomplish all our works like those which are done in broad daylight, in the presence of all people, then we should yet be well off, for he who does evil loves darkness and hates light. 5

Do you suppose that on that great day on which all works shall be revealed that noble Roman, who, after all, was only a heathen and did not know the true God, will put us Christians to shame, because he did not wish that the mason or builder should build him a house in which no one might see what was happening, but on the contrary desired that it be constructed in such a way that everyone would be able to look and perceive what was going on in it? 6

These and similar thoughts occupied me till we finally came to the abovementioned little town; and the conclusion which I came to 
was this: That that man is not unjustly to be accounted godless and forgetful of God who does not keep in mind or disregards the continuing presence of God; but that that man is God-fearing who, in all his actions and transactions, in all his commissions and omissions, unceasingly keeps in mind, observes, and respects the undeniable, certain presence of the Almighty; this way it seemed to me quite easy to attain a pious life, pleasing to God. With so little effort, I told myself, an inestimable treasure, namely, eternal salvation, can be won; and as I thus continued my deliberations, it occurred to me that God is present not only outside of us, as people are wont to be with other people and to belong together and to watch one another, but rather that $\mathrm{He}$ also sees and knows the present and future innermost emotions, thoughts, and designs of our hearts.

Therefore I resolved to become a completely different person; I forthwith gave up the plan I had in mind, to rob a rich Jew in Poland in order to enrich myself through theft, particularly since the seventh commandment forbids stealing under any conditions, and anyone who steals is a thief, whether he steals from a Jew or a Christian.

When I came through the gate of the oft-mentioned little town, a heavy cloudburst occurred, for which reason I sought refugium in the nearest house, to keep dry. In it dwelt a rather old cobbler, who was sitting there and working at this trade, while his young wife was spinning hemp into twine; I saw neither children nor servants, but quickly apprehended from the couple's discourse that the master's real, and the woman's stepson was at market selling shoes.

I had not been with this married couple for more than a half hour when another fellow came in who complained to the cobbler that his shoe was pinching him mightily on the big toe of his right foot, with the request that for a fee he should help and advise him how he might be rid of his concern. "But of course!" answered the master. "Off with the shoe, and I shall stretch it over the last a little and shall have soon 
gotten rid of the trouble." The patient was more than happy to comply, and the shoe was taken off, wetted down, and a last forced into it, which was to remain in it for about a half hour, till the shoe dried a little, so that it would keep its shape. The monsieur asked the cobbler what it would cost, and received the reply that a measure of wine would be more than enough. "Fair enough." said the other. "You can surely see by the look of me that I too am thirsty now. Look you, master, here is money; fetch a measure." "Wife," the cobbler thereupon said, "go fetch it so that meanwhile I may continue working." But this did not suit the galant homme; therefore he said: "But your wife must also bring along a few dozen pasties for me." "Most willingly!" answered the cobbler's wife. "But how? They will get wet from the rain." And to her husband she said: "And everyone will see what I am carrying." "That is easily taken care of," answered the cobbler, "I shall take my coat and fetch both wine and pasties myself." This was no sooner said than done.

But hardly had he turned his back when the two left behind glued their mouths together so hard and fast, embraced one another, and altogether could not leave off from each other, so that I thought to myself that they had been stuck together with a lump of pitch; and that was not all by far, for this cunt-hound threw the good cobbler's wife onto a couch which was there, and assumed with her such a workmanlike position that anyone, unless he be a stupid ox, could easily discern that he intended to treat this little married woman the way the cobbler had treated his shoe. She, to be sure, did not grow angry at this at all; I, however, felt vexed at heart that he wished to present such a spectacle for me right there; therefore I sneaked down to the foot-end of the bedstead, grabbed him by both feet, and pulled him, just as a plowman, as it were, plows a furrow lengthwise in a field, all the way down over the footboard, to which he clung with his hands and by his cherry-picker nose, otherwise I should have 
dragged him further, and perhaps even right out into the street. Everyone may imagine and guess for himself what these two thought about this. To be sure, I know not what they thought, else I should tell this also. But this I do well know: They looked at each other with astonishment, and were trembling with fear, anxiety, and terror. The first words they spoke to each other were that each asked and said to the other: "My God! What was that?" But I thought to myself: Had you both but said that before you began your accursed acrobatics, you might have done so with a clear conscience, and not, as now, with one filled with trepidation.

I had pulled the fellow's nose so carelessly against the footboard that he was bleeding like a stuck pig, but I was little aggrieved by that, but rather wished that I might bleed all such studs in this fashion, and thereby empty their hearts of their hot, lecherous, adulterous blood. The cobbler's wife, for her part, was much more charitable, and spared no pains in consoling, wiping, and washing, which got my dander up once more, and moved me to pour over her head a tub full of water which was standing beside her husband's workbench, together with the softening leather, shoes, pitch, and whetstones which were in it. This done, I went my way, because it had stopped raining anyway; nor do I know how these two further helped each other out, nor how they divided up the pasties with one another when the husband returned. 


\section{chapter seventeen}

From there I went further into the town, and, to be sure, into a house which to all appearances was not one of the poorest by any means; in the hallway downstairs stood a man in a coat who was holding something under it and was waiting attentively; meanwhile the master of the house descended the stairs, followed by a few town officials, from which I surmised that he must needs be a high-ranking personage in government, and by his fat paunch and large head I could discern that he was in clover, as it were. The first man made a deep bow to the second one, and when he was asked what he wished, he answered: "I wish to most devotedly recommend to Your Honor once more my just suit against N. N. ${ }^{1}$ and to beseech Your Honor to be so kind as to act most generously and to exert your influence so that it may be expedited to the desired conclusion before the highest authority." "What do you have there under your coat?" asked Fatbelly. "Are those perchance papers or briefs pertaining to the matter?" "No, Your Honor," answered the first man, "it is merely a small token of my gratitude, in recognition of your manifold efforts in my behalf, which I present with my devoted assurance that I shall do better after the final verdict."

"What?" the other thereupon said with threatening mien. "What do you take me for? Do you think perchance that you would be done an injustice if I should put you in the madhouse for a while? My dear sir, justice will be done, and without any gratuities from you. This time I shall overlook your lack of good sense, but do not approach me in this manner again, else I'll show you what's what!" And with that 
he walked out of the house. This reprimand pleased me mightily; the two town officials, for their part, loudly praised the honesty and integrity of their honorable mayor, whom the frightened supplicant followed quite sadly at a distance, like someone who has upset the applecart, so that I almost felt sorry for him.

But he was straightway exceeding well consoled again, for the lady of the house had her maid call him back, and asked him in a very friendly manner what business he had had with her husband. Thereupon he complained to her of all his troubles and concerns, of which the one which troubled him most was that he had angered her husband. "Do not worry!" said the wife. "Just now he is much preoccupied with a worrisome and important matter concerning the whole town which he is turning over in his mind, for which reason he was barely able to get a wink of sleep all last night. What is it, sir, which you wished to give him?" "This piece of fine cambric," answered the fellow, and with that he pulled it out. The wife looked at it and praised it as better than any other linen, and said: "Sir, just leave it here, and I shall put it to my husband when he is rid of his worries, and not only get you back in his good graces again, but also see to it that he shall help promote your suit as much as possible." Who was more pleased than the good supplicant that he was permitted to express his gratitude for the honor and pleasure which were his, because, in defiance of all justice, they relieved him of his goods! I, however, thought to myself: That's honesty for sure! Scratch my back, but whatever you do, don't touch it!

I had intended to straightway punish fittingly such godless actions as might henceforth take place in my invisible presence, as I had done in the cobbler's house, but here I had no idea how to act in such a way that both he who had greased the palm and she who had had her palm greased might receive their just deserts and reform, and yet in such a way that through my actions neither would 
be treated unjustly. I thought to myself: If the supplicant has a just claim, then why does not the mayor, ex officio, ${ }^{2}$ grant him his rights without accepting any gratuities? But if he is not in the right, then why do they take the palm-grease? Item, if the fellow is in the right, then why must he buy justice with gratuities? But if his claim is not justified, then why do they not tell him so immediately, and let him go on his way with the rest of the poor folk?

In pondering how to carry out my plans, I well realized that my invisible presence was not always and everywhere an advantage, and that the wondrous bird's nest had not been bestowed on me in order to pillory and punish all the world's folly and misdeeds, especially since in this case I was unable to ascertain who was right and who was wrong, who should be punished and who was innocent. I thought of Abraham's words to the rich man in hell when the latter entreated him to warn his brethren, namely: "They have Moses and the prophets; let them hear them." 3 What, I said to myself, if these people do not believe and obey the word of God as revealed in Holy Scripture, which they have daily before their eyes, to which they are referred from childhood on, and which is also daily held up to them, interpreted, and through which is explained to them the holy will of God-what, then, will your fleeting voice be able to accomplish with them, a voice which, to be sure, might frighten, but not reform them, because they may just as well, if not perhaps sooner, perceive and take it to be the voice of an infernal spirit rather than a sincere admonition.

Therefore I let these people be as they were, and wished for them that they might have such a firm resolve that they might not only keep ever in mind the presence of God, so as to avoid all sin, but also, as I intended henceforth to do, zealously study Holy Scripture and learn, by reflecting upon it, how we should honor God, love Him and our neighbor, and serve them both. 
In the midst of these thoughts I began to feel hunger and thirst. Now, where take anything without sinning? I asked myself. I still had a ham which I had snitched in the monastery; that was all the victuals I had left, and because I had not got it honestly, I had a bad conscience about eating it. However, I thought: It is better that the hungry be fed from the superfluous riches of the monasteries than that such superabundance be employed on useless splendor, horses, tack, coaches, theatres, etc. God has not put you in this world to suffer hunger in it, but rather to enjoy His gifts. What be the harm, even if you were to snatch a loaf of bread from a baker to fill your stomach with it? After all, are not the hungry, in their need, permitted to take as much food as they require? 'Tis better that you take what your rights permit you than that you become a suicide by starvation, against the will of God, against nature, and against the laws of the world.

This was what I was thinking, and in so doing I did not perceive that this manner of excusing sin is itself a sin. I did not think of the fact that it was much more fitting for me, a strong young fellow, to earn my food through labor or some other honorable trade than to snitch it in such a thievish way from other folks; even less did it occur to me that there is a great difference between the poor miserable man who can neither work nor find anything to work with, and a vagabond who is wandering about invisible, as I then was, and who should really well be able to earn his own keep. Consequently, the genuinely poor man is allowed to take what he needs to stay alive, whereas one like myself deserves to be put in gaol.

Paying no mind to what I was doing, I took a loaf of bread from a baker in the public marketplace, and did not think that this was any great sin, but rather ate of it and of my ham so heartily that in less than half a quarter-hour my thirst had doubled. I did not know how I might get any of the sweet juice of the grape; therefore I looked 
for strong Breslau or Striegau beer, ${ }^{4}$ and when I happened upon it in sufficient quantity, I filled my belly so full of it that I was almost unable to bear it any longer; therefore I loaded it onto a wagon which was standing there ready for the trip home. Several peasants, blind drunk on beer, sat down in the wagon with me, together with two women from a neighboring village, in which fine conveyance I arrived that evening, after three hours on the way toward home, at a village where I spent the night in the haystack of the local inn. 



\section{Chapter Eighteen}

The following morning I walked perhaps three miles on the way toward home without having eaten or drunk anything, for, as stated above, I was no longer willing to sin, much less to steal money from a Jew, or from anyone else, but rather, while walking I entertained all sorts of thoughts about how I henceforth intended to keep God in mind, to reform myself, live piously, and arrange my actions and transactions at home in such fashion that I might thereby attain eternal life. On the way two fellows joined me, one of whom was a great adventurer, or at least claimed to be, for he boasted of the extensive travels which he had recently completed and had survived at great peril to himself. He tried to hide his mother tongue and to speak Flemish or Westphalian, like that Swabian lad in the Wurttemberg complement during the Swedish Warl who, when he was quartered in Breisgau, said to his host: "Fathir, gie me a wee bit to maunch on," but then forgot himself and went on to say: "and $\mathrm{Pa}$, gimme a piece o' brayid too!"2 He no longer spoke of halfpennies and pennies, much less of groats, lucernes, shillings, or any other German coins, but rather dealt only in Dutch guilders, British pounds sterling, French sous, Polish zloty, British farthings, coppers, deuts, or at least silver pennies, making it sound as if he had begged his way through the greater part of Europae. And he told his comrade, or traveling companion, what wondrous strange things had happened to him on his perilous journey, how he had here and there survived many a danger to life and limb; and sometimes his flights of fancy took him so far that I actually feared that he might not find his way back to 
earth again. It was particularly amusing to hear him tell how when he had just been approaching his fatherland again, to his misfortune Charles IV of Lorraine and the Count Palatine had been fighting a war with one another on the Rhine, ${ }^{3}$ for which reason it had been extremely unsafe to travel on the roads in broad daylight; therefore, heeding the warning of honest folk, he, together with another traveling journeyman, who was a simpleminded and fainthearted ass, had been obliged to take to the road mostly at night, and had once gotten lost in a forest in which they very nearly drowned because of a great rainstorm; but they had not stopped walking till they saw a light from afar, whereupon he had sneaked toward it, and had left his comrade standing some distance from it under a tree.

Now when he arrived at a little house in which this light was burning, he had peeked through the window into the room, and had seen therein a young woman who had just finished her evening meal and was getting ready to go to bed. He had knocked on the door and asked the wench for lodging for the night for himself and his companion, and had been granted it, and had thereupon gone back to fetch his comrade, but had not found him, wherefore he returned alone to the wench in the little house, and was commanded by her to lie down with her in her bed, on the side next to the wall. Thereupon he had undressed and climbed over the woman, who was lying on the side of the bed away from the wall, to his assigned place. There he had lain warily for a while, to be sure, but had not been able to sleep at all, but rather was plagued by all kinds of worrisome thoughts and scruples, till finally the observation of his chastity had forced him out of bed again, regardless of the fact that actually he had been right warm lying next to the oft-mentioned young woman. So then he had quickly snatched his clothes and with them had whisked out of the house. And he had not stopped running either till, toward daybreak, he was happened upon by a party of Lorraine troops, seized by them, 
and led to a hill where a whole company of their cavalry was keeping watch; and because there was no one among them who was able to speak with him, they had given him something to drink, to be sure (for they had a quarter-pail of wine with them), but had also given him cuffs aplenty, pushed him around, and forced him to play the fool. But when the wine had been guzzled up, they had stuffed him in the barrel and let it roll down the hill, during which journey, as is easy to imagine, he received grievous bumps and bruises about the head, arms, and legs. The barrel finally came to rest, with him in it, on the plain below, on a patch of grass (it must have been a knacker's yard), to which had come not long thereafter, to his great good fortune, a great big wolf, which kept going round the barrel and sniffing it, till through the bunghole he had grabbed it by the tail and begun to shout, for which reason the wolf had run away with him and the barrel till it ran between two trees standing close together, where it had strained to rid itself of the barrel, which had got stuck between the trees, but it had not been able to accomplish anything because he had held on so tightly to its tail. Not long thereafter he had heard a drayman approach, for which reason he began to scream terribly and pitiably for help; thereupon the drayman had sent his helper over to see what might be done, but when the helper had seen this odd sight and, out of fear, had not approached the barrel, the drayman had finally come himself, but he had behaved just as fearful and affrighted as his helper, keeping at a distance, since he took both the wolf and the barrel to be witchcraft, till finally he had held his rosary out the taphole and shouted that he was a Christian, and they should save him from both the barrel and the wolf, whereupon master and helper had run up with an axe, hacked the wolf to death and the barrel open, and had thereby freed good Monsieur Raphanum (for this was the name of the gentleman to whom this misadventure had happened), and had released him from further danger. ${ }^{3}$ 
Now when the traveling companion of Raphani showed by his demeanor that he was undecided as to whether he should believe or disbelieve this tale, Monsieur Raphanus grew angry and asked him whether he doubted his words, or whether he thought that this tale was not true. The other one said: "I should surely like to believe you, sir, and even if this tale were not true, it is certainly amusing to listen to, and also serves to shorten the way considerably." From then on, there were yet several more insulting exchanges, for which reason the two very nearly went at each other's throats.

By this I saw what great folly it is when someone attempts to make himself appear great and estimable by braggadocia and stories of wondrous and yet impossible events which are supposed to have happened to him. A fantasist of this stripe does not see that other people are clever enough to recognize his lies for what they are, and to secretly laugh at his foolishness. Ariosto teaches us in one of his satires that one should not argue with his master in any case when he writes:

Pazzo, chi al suo Signor contradir vuole,

Se ben dicesse, da mezzo giorno

Visto ha le stelle $\&$ a mezza notte il Sole. 4

That is:

'Tis folly to cross your master, for he is always right,

Although he claim at noon the stars are twinkling bright, Or claim to see the sun aglow in darkest night.

In the little village to which I came, there was, just at that time, a church fair and a wedding too, for which reason many people from outlying areas were present. They spared neither wine nor beer; there was no lack of drink or food, either cooked, roasted, or baked; they danced, they caterwauled, they sang, they hopped about, and they played; in summa they left nothing undone which might contribute to fun and merriment, but rather did anything which might increase 
it. Now because I was hungry and thirsty, I felt all the less guilty about enjoying the food and drink, but only that which was present in superabundance and which was being urged on the guests in every manner, shape, and form by the natives of the village; in particular, I partook of so many spicy holiday cookies that after them the exquisite drink tasted all the better to me, and benumbed my brains just as quickly as those of the villagers and their guests, with the result that, without realizing it, I lost control of my senses completely, staggered about, and barely kept enough wits about me to go upstairs in the house to seek a resting place where I might safely sleep off my blind intoxication. I say "safely," for I no longer had sense enough to creep nice and cunningly, as was usually my wont, into a hidden corner, but rather, when I happened by accident into a room in which there were two beds, I lay down in one of them without taking any precautions, or giving a single thought to what might perchance befall me there; in summa, I let God and my heedlessness prevail. Heedlessness I assuredly demonstrated, but God, Whose presence I had-while sober, to be sure-resolved to keep firmly in mind, I now — while dead drunk — so little remembered that I did not even commend my body and soul in prayer to His all-powerful protection. Look you, for God's sake, so greatly had drink benighted me!

Nevertheless, stupid fool that I was, I was so bold as to sleep on, without a care in the world, till about midnight, when every man, every wife, every lad, and every lass thought they were sufficiently tuckered out. The first who were brought into this room by the innkeeper and laid onto the other bed next to mine (and who also awakened me from my first sleep) were two sisters who, like me, had taken unto themselves and partaken of more drink in the inn than at the consecration of the Holy Ghost in the church. They bade the innkeeper also to bring their cousin to them forthwith, and to put her, and no one else, in the room with them; this he promised, 
and thereupon brought a comely young girl who laid down half undressed (for it was a warm night) next to me on the bed where it was still made up, or appeared undisturbed.

Anyone who likes this sort of choice morsel can well imagine how I felt, especially if he considers that at that time I was still flushed with drink, and had not yet slept long enough to come to my senses; therefore I behaved like a mindless beast, and remembered little more of my good resolve, namely, to keep God's presence ever in mind, in order to avoid sin. In a word, I groped about me and found my bedmate drugged with both wine and sleep, and also deluded by I know not what manner of illusion, by virtue of which she called me her darling Peter, and not only permitted me to do everything with her I pleased, but even staunchly helped me.

In such sinful debauchery I spent the rest of the night till day began to break, and my erstwhile virgin fell asleep, whom I then left to sleep undisturbed, and as soon as the light of day shone but a little, I took to my heels. However, how this church fair later on profited the good maiden, of that I have since had no news. 


\section{Chapter Nineteen}

Even before sunrise I came to a pretty little woods wherein I laid down and slept again till I was completely rested. I was awakened by some cattle which were being driven to pasture, and just as I awoke and was rubbing the rest of the sleep completely out of my eyes, their herdsman was about to commit a terrible sin, such as cries to Heaven. ${ }^{1}$ At the sight of this my hair stood on end, and so that I might frighten him off from doing it, I yelled to him at the top of my lungs the words of the peasant lad whom I praised above, namely: "Desist, poor man! You are not alone! The devil is enticing you, he is watching you and laughing, but on Judgment Day will nonetheless accuse you of this sin; the angels are watching you with sorrow, they are pitying you because they are not able to excuse this sin; God is watching you, God, Whom you are most grieviously offending and angering, God, Who will also punish you for this." As soon as the herdsman heard this voice so close to him, but yet did not see anyone, he grew rigid with terror, so that he stood there as if turned to stone, and when he had recovered somewhat, his pangs of conscience drove him to tie one end of his whipcord around his neck, and the other to the limb of a tree, with the intent of thus cutting short his own life. Who was more affrighted than myself, since by shouting to him I had given him cause and reason for this terrible suicide!

Therefore I prevented him from carrying out his intent by actually laying hand on him. "Are you," I said to him in a loud voice like someone scolding him, "going to run straight into hell because the Evil Spirit has persuaded you that you cannot escape it anyway? Are 
you going to make so bold as to assure, by committing suicide, your certain damnation, which you know you have deserved for your sins, and to double your sins by blasphemously despairing of the ineffable mercy of our Heavenly Father? Do not do it, my child! Turn back, do penance, and mend your ways, so that our loving Father, in His merciful benevolence, will have cause to reward you, save you from the eternal torments of hell, and find you worthy to enjoy, together with His chosen people, the Kingdom of Heaven!"

The fellow was so completely stunned and shocked out of his wits that I know not whether at that moment he was to be reckoned to the quick or the dead; but finally God took mercy upon him, so that he reflected upon and paid heed to my words; he fell to his knees, lifted his eyes to heaven, beat his breast, and sighed with gestures of lamentation, saying: "O God, in Thy boundless grace, have mercy upon me, a poor sinner!" And after he had repeated these words over and over again, with tears in his eyes and with piteous howls, he said: "O, my Lord God, what am I to do so that I may regain Thy divine grace and mercy? What am I to undertake so that I may escape Thy wrath? How must I proceed so that, like a prodigal child, I may be taken again into and unto my Father's house and grace? But since I may hope for consolation and mercy from nowhere other than from Him Whom I have angered and Whose grace I have so churlishly forfeited, so that I very nearly dare not come to the Throne of Grace, alas, in what manner am I to attain it again? Alas, to what procurator can I address myself," etc.

He uttered many more melancholy words of that sort, so that I rejoiced at his remorse, and at the same time was moved to heartfelt pity; therefore I said to him: "My child, show thyself to the priest,2 and heed thy pastor's counsel, and whatever he saith unto thee, that shalt thou do, and then thou shalt find peace for thy soul." "O, blessed angel," he answered me, "who art thou, who hath deterred 
me from my sins and hath saved me in this wilderness from ultimate perdition? Tell me who thou art, that I may thank thee for thy beneficence!" I said: "I am not an angel, but a voice which God in His great mercy hath sent to thee so that thou mayest return to Him and live; thank Him, and obey the command which instructs thee to seek the word and counsel of the priests, in the firm faith that God will receive thee once more into His grace; for if this were not so, He would not have sent me to thee, which thou shouldst well consider, and not put off to repent of and mend thy ways, but rather thou shouldst recognize God's bounty, which thou hath received, and thank Him for it from the bottom of thy heart."

I resolved, moreover, to remain with the herdsman, in order to prevent him, should he perchance again be tempted, from committing the first or the second sin, till he returned from the wilderness to human society, and would be able to seek out a priest.

Meanwhile, however, I looked into my own soul, because I was unable to lay claim to a clear conscience myself. Who are you, I said to myself, you who are mired in sin up to your ears, and wish to show others the way to heaven; have you thought even once of your own conversion? And yet are so impudent as to teach others what you yourself have never sincerely undertaken to do for the salvation of your own soul? Will it not redound to your even much severer damnation if this miserable, benighted herdsman, who has perchance sinned out of mere ignorance and bestiality, has returned to God because you urged him to, while you, who by the grace of God have certainly known all along how to distinguish between good and evil, and between what you should and should not do, not only have not left off your sinning, but also have not even begun to mend your ways? Will it not make your damnation all the greater, you monster endowed with reason and sufficient knowledge, if this herdsman's ingenuousness bears testimony against you on that great and terrible 
day, by carrying off the laurel wreath of the truly repentant because of a few words which he heard from your equally sinful lips and heeded, while you, who knew more and better about sin and salvation, travel the road to hell?

Do you also know, I further said to myself, how you, you drunken swine, spent last night, like a mindless beast as it were, and like a rutting billy goat and a depraved satyrus (the assumption of whose form is the greatest delight of the spirits of hell), and robbed a pure virgin, whom you did not even know, of her most prized jewel? And this, in fact-which is even more horrible-straightway after your faithful God had taught you, by showing you examples of how other people's actions were harmful to them (in whom you should have easily seen yourself reflected), that you should keep His presence ever in mind, and should always venerate it to your profit. You monster in disguise, who have made yourself like unto the Prince of Darkness and, by means of your sinful body, have perpetrated a fraud so unheard of that even the Evil Spirit himself would not have undertaken it: indeed, you would like to imagine that the good maiden liked it, and was well satisfied by what you did; but do not deceive yourself! You well know of your imposture and of the circum- and happenstances, all of which were such that Chastity herself (were it indeed possible at all to seduce her) should not have been safe from you, nor able to prevail.

Meanwhile, the herdsman drove his flock home, and along with him, I followed the other, four-legged, beasts; he sighed, and I wept; I followed him right to his hut, where he put down his whip and staff, together with his shepherd's pouch, and hurried to the church and the parsonage, where, to be sure, he found the sacristan, but not the parson, who had gone to a feast in the neighborhood and did not come home till late at night, as drunk as a hootowl, with the result that the poor shepherd could that day hope for little help and 
consolation from his shepherd, but rather, because of his minister, he was obliged to let slip away, to no avail and use, the first ardor of his period of grace and burning desire to reform which God had benevolently granted him, at which I secretly railed in my heart, and asked, I know not whom: What manner of tender of his flock is one who is not with his flock? What manner of parson is one who is not in his parsonage? What manner of bishop one who does not remain with his sheep? Why does he help celebrate, with more wine than holy water, the funerals of those who have passed away and already gone to their destination beyond his parish, and yet the sick lambs of his own flock, who are particularly entrusted to his care, he permits, for want of the medicine which he is supposed to impart to them, to nearly pine away miserably in this wretched life, which is a continual struggle?

O, mon dieu! I said, as the French do. How will it all end? With these angry thoughts I went home with the sorrowful and anxious herdsman, because I intended to leave him nowhere save in the hands of a priest, for fear that he might once more fall into temptation, whereby I might perchance come to his aid and comfort. Thereupon he and I spent a sad and sorrowful night: he, to be sure, because he was remembering what he had intended to undertake that very day; I, however, because I knew what I had in fact done the night before. Eating and drinking, not to mention singing and dancing, were the furthermost things from both our minds; indeed, both our states of mind were such that sleep, otherwise so pleasant, did not please us.

For that reason we were up all the earlier. The shepherd hired another man who was obliged to drive his flock out early in the morning and tend it that day; he himself, however, was obliged to assuage with patience his aching soul till its shepherd had slept off his drunk, which dragged on till about nine o'clock; then he appeared before him with fitting humility, and I left them together in the church and 
continued on my way, with the intent of following him in honest penitence.

That same entire morning I did not encounter anything worth telling, and for just this reason I had all the more leisure to spend the time pondering upon my own condition, item, on what I had resolved to do and yet not done. I then discovered from my own experience that it is indeed an excellent means to avoid sins, and necessary for man, in humble reverence to keep God's presence ever in mind and memory (which is man's duty anyway), but that for a beginner this is not yet enough, unless at the same time he call without surcease upon our faithful Lord for help, mercy, and succour, so that He may not allow man, in his miserable frailty, to fall; but especially that man should also, here and now, earnestly observe and do the following: namely, avoid all dubious places where he might possibly sin, even though he have the firm resolve to sin no more, for opportunity makes the thief, and we know that quicksilver so stains even the very purest gold that it will not again recover its former luster and beautiful color save through fire; and for this very reason people who wish not to evoke the wrath of God should be wary of all places and occasions, but particularly yield no more to strong drink, or trust the company wherein it is found, nor should they rely upon themselves, no matter how great the steadfastness of their resolve may be. In this manner I pondered upon my condition, and the longer I did, the more I became aware of my vacuousness, and the more I recognized my own stupid ignorance and trifling capabilities; and from that was easily able to conclude that if I did not, with unceasing zeal, pay heed to the welfare of my soul in a different and, in fact, better way, and if I did not struggle more earnestly against my sinful desires, and hold them more carefully in check, the salvation of my soul would be on shaky underpinnings. 


\section{chapter Twenty}

Now, thus contemplating this weakness, past errancy, and great ignorance of mine, I laid down under a tree and watched with what great care and caution a little forest bird 1 picked up from the ground and carried off both its nourishment and the material for its nest. It never alighted on the ground without first looking to see whether nets or snares might not have been laid there to catch it. It never picked up a single seed without first looking around several times to see whether a hunter was hiding and lying in wait who might perchance be able to shoot it. It never flew back into the air, its very own element, without first considering the safety of the path it wished to take, and whether any bird of prey was there which might carry it off, feathers and all!

You stupid, wanton fool! I said to myself. Why are you so bold as to believe of yourself that you, like other people, are possessed of reason, and yet for your own self-preservation you do not show as much reason and caution as this mean creature which, after all, has naught to worry about save losing its worrisome life, and not, as you do, the crown of eternal salvation-this mean creature which need not worry, as you must, about eternal damnation after its death? With these thoughts I resolved to learn henceforth from all creatures of this sort anything which might be salutary to the advancement of my own salvation, for from this single example I was quite well able to conclude that God in His benevolence had created them not merely for our sustenance and delight, particularly since some of them 
are poisonous and unfit to eat, while to consort with others is very unpleasant, harmful, loathesome, and dangerous.

Straightway thereafter I saw a big ugly toad waddling along which, I know not whether because of an overabundance of fat or of poison, or because its belly was full of spawn, was barely able to crawl, much less to escape a snake which was pursuing it and which, before my very eyes, caught it and swallowed it! These two loathesome vermin reminded me that I should be obliged to continually thank my most benevolent God for not having created me such a monster, but rather a reasonable creature who is able to attain, like the holy angels, eternal salvation.

Now while I was learning from this toad how grateful I ought to be, I also learned that a man who is burdened with pride (which the toad's pompous gait had brought to my mind), or one who, day and night, stuffs himself like a pig with unnecessary food and drink, or one who is a slave to poisonous envy, hatred, and rage, or one who is always serving carnal lust alone, or one who because of avarice has burdened himself with too many worldly and perhaps ill-gotten riches, or one who because of sheer sloth refuses to travel the path to heaven, is almost like this toad, and will escape only with difficulty the serpent, the dragon of hell.2

Now because these thoughts of mine were bearing palpable fruit, look you, I pursued them further, and indeed came to the point of venturing to learn not only from visible creatures, but even from the archenemy of the human race, the devil himself, whom I had repudiated!

For when I considered in what measure this accursed fiend so earnestly pursues us human beings, out of pure envy and spite, with unflagging exertion, uninterrupted zeal, and innumerable tricks, deceits, and inconceivable ruses, in order to lead us into sin and thereby deprive us of divine grace, mercy, and eternal salvation, from which 
he can hope for no profit, no benefit, no gain, no recompense, nor anything else of the sort which might content him, save alone that hereby he attempts to inflict his own evil will against the most holy will of God (that is, as it were, to vex and spite God) - then I thought to myself: You blind fool! You, who after this life have before you and can expect only one of two things, and, moreover, have the choice between the two: namely, heaven or hell; eternal life or eternal death; the everlasting torments of hell or the everlasting joys and delights of heaven; the most blissful contemplation of God and of his dear angels and chosen ones, or the fellowship of the frightening spirits of hell and of all the damned: why do you allow so many hours, so many days, so many weeks, months, yea (alas) so many years to pass without ever even thinking of this, when, after all, accursed Satan never rests a minute in attempting to deprive you of your salvation, but rather walketh unceasingly about, seeking whom he may devour. ${ }^{3} \mathrm{O}$, you heedless fool! I said further to myself. Why, after all, do you not consider who you are, who you have been, and what you can become, or, in the end, must become! Why do you not make better use of this period of grace which God in His beneficence has granted you to attain the salvation of your soul, this period during which the devil does not rest in his efforts to drag you to him to eternal damnation.

As I was sitting there thus bemused, a nightingale in the tree which I was under began to sing so sweetly that it must needs have delighted the heart of anyone who was not laden down with such thoughts as mine; but as it was, the pleasant loveliness of her song deranged the train of thought which was occupying me, and caused me to ponder upon what I might learn from her and her happy song.

It is obvious, I answered to myself. She is enjoining you to praise your Creator!4 Whom? said my sensual self to me. She may well sing, she may well sing. She has no debts to pay. But were she suffering such pangs of conscience as I, she would soon enough leave off her 
fluting. You unreasonable ass! answered my rational self, for its part. Do you not know that a broken spirit and a contrite heart are sacrifice to God?5 Do you not know that your sorrow, your troubled tears of repentance, and your grieving that you have incurred the wrath of God are as pleasing to the Creator as is the song of the nightingale? Particularly when this pain stems from love for God, when you rue that you have offended your most benevolent Creator, and when you have the firm resolve to mend your ways and nevermore move God to wrath. Arise, go quickly, and hasten without delay to make yourself again, through true repentance, like unto this blithe and blissful nightingale! Cleanse your heart through confession, and let your sins be blotted out through absolution, and then your faithful God, who most graciously enjoins you to do this, will give you joy and gladness, so that the bones which you have broken may once more rejoice. He will create in you a clean heart, renew within you a right spirit, and uphold you with His free spirit; then He will open your lips, and choose to let your mouth show forth His praise; ${ }^{6}$ then $\mathrm{He}$ will be pleased with the sacrifices of righteousness, the Holy Lord, Who otherwise rejects all praise from the mouths of those sinners who do not wash away their shortcomings and iniquities in this fashion through the power of the most holy blood which the innocent Lamb shed for them.

Such and similar thoughts I turned over at that time in my sorely troubled mind, and so that I might set my affairs aright again as soon as possible, and, with the assistance of divine grace, put myself into such a state as would be pleasing and agreeable to God, I proceeded on my way home in all haste in order to show myself to the priests, to follow their counsel, and in all humility to subject myself to their commandments as to the commandments of God, in Whose place they sit. After that, at the height of the noonday heat, I passed through a village in which a butcher had just dismounted and tied 
his horse in front of a house to a post as thick as your arm on top of which was a beehive. I happened by just as a bee was buzzing about the ears of this strange guest, which the horse did not wish to suffer, but instead jerked back its head and broke off the post to which it was tied right above the ground, where the post was rotted and wormeaten. Kerthump! The beehive lay on the ground, which so enraged the honey-makers that, in order to wreak terrible vengeance on the poor horse for destroying their kingdom, they flew out in battle formation, wielding their stingers like lances at the ready, as it were. To my misfortune I happened, as mentioned above, to be present at this rencontre, and thought myself to be just as safe from the angry honeybees as I was invisible, but I was far from the mark, for since they did not see me, but rather thought they might fly through my body as if through the air, I caught in a trice a few hundred hooks, most of which went through my shirt and into my skin, because on account of the great heat I had taken off my jerkin and hung it over my back. What pain and torment I endured at that time can neither be told, nor described, nor believed, but one may get an idea of it from what happened to the horse, which went quite mad because of the terrible pain, ran back and forth in the village, and behaved so frighteningly that in the end they were obliged to shoot it. I, however, lay down in a stinking cloaca to escape further persecution by the honeybees, and I could not but think that I was already suffering the torments of hell.

Now learn from this, you overconfident fool! I said to myself. You miserable wretch! You, who thought yourself sufficiently safe from all powers in the entire world; you, who believe that all your deeds, actions and transactions, are sufficiently hidden; you, who do as you please and think: Who the devil is to stop me? How easily the divine presence of Almighty God, Who is everywhere, can find you and either, in His benevolence, merely humiliate you, or, in accordance 
with His justice and unfathomable judgment, instantly cast you even into the jaws of hell!

From the above-mentioned loathesome bath I betook myself to another, namely, to a flowing stream, because I had emerged from the first one so befouled that in fact no one (provided anyone should have been able to see me) would have believed me and taken me to be a man, but rather, probably, to be a pillar of shit (if you'll pardon my saying so). In this latter, or second, bath, to be sure, I rinsed away my external defilement, but I could no more rid myself of the pain from the stingers sticking here and there which the swarm of bees had stuck into me and left behind in my skin as a good reminder, than I could rid myself of the anxiety which was besetting me-into which, in fact, I had plunged myself through heedless wantonness.

Thereafter I undressed down to the buff, and dried my clothes behind the hedge in the rays of the sun, which was gradually moving toward the west, which took so long that I was obliged to make do during this to be sure short summer night in the very same woods in which perchance the Hopalongian hurdy-gurdy girl had dwelt, and where she, in the form of the mysterious Melusina, or water sprite, had first met and ensnared her honest baker boy. In the morass in which I had been, the food which I had had with me had been ruined and had become unfit for consumption; for that reason I was obliged to suffer hunger, even though I had taken neither food nor drink the whole day before. But what a merry night I otherwise spent, compared to the one before, my dear and esteemed reader can easily imagine for himself.

But 'tis better to suffer here than in the hereafter; and by taking this maxim to heart I consoled myself as best I could, particularly since the pains from the bee stings either gradually abated, or I finally became accustomed to them. 
Anyway, early the next morning I felt well again, without feeling inwardly fatigue or the desire to eat, but outwardly feeling a soft velvety swelling here and there on my body. My thoughts that night had dwelt with wonderment on naught but how God the Almighty is able to employ even the least of insecta to visit upon and chastize his wayward children, and therefore need not send as punishment terrible plagues and disasters; early in the morning, however, I realized that God, in His infinite goodness, conceals healing medicine and remedies in even mean and contemptible things, since I too ascribed the cause of my so swift recovery to be the cesspit in which I had lain, since we know from experience that when you wash bee stings with urine, both the pain and the swelling instantly go away.

Now when I further weighed in every way my state of affairs at that time, and regarded both the future and the past, namely, what had happened and might yet happen to me, and in addition was able to comprehend that all the untoward things which had happened to me had come about because of the bird's nest, I began to grow sick and tired of it, particularly when I reflected that its former owner had lost her life in such miserable fashion because of it, and had been burned as a sorceress. I judged that it must needs have about it some property which, like the horse of Sejanus, ${ }^{7}$ plunges its owner into misfortune; nor did I see how it could be particularly useful to me, unless, by its power of invisibility, I wished to steal, which, however, had become a repugnant abomination to me, even though earlier I had it so firmly in mind to do. To be sure, I rather regretted giving it up, not only because it was rare and the sort of thing for which many a great lord, for his own amusement, would have paid me a great deal of money, but also because it was able to rescue one from danger and release one from the power of any human being. But when I considered what a great calamity it might bring to the world, were it in the hands of a powerful lord, and were perchance misused, 8 
especially since in my need I now ought to rely not on this bird's nest, but on the help of my true God, unless I meant to value this nest more highly than God, which, however, would be the greatest idolatry in the world-look you, I made the judgment that it should be forthwith cashiered and annihilated, and therefore took it out of my shirt and tore it into at least seventeen-hundred pieces. ${ }^{9}$

"Get thee gone!” said I. “On account of thee, henceforth no man's secret doings shall be seen and revealed by another; because of thee, henceforth no one shall ever be robbed of food or drink, much less of money; henceforth thou shalt point the way to neither men nor women, nor provide cause and opportunity for them to befoul themselves dissolutely in acts of lechery; thou shalt conceal with thy invisibility neither my, nor any other men's knavish and whorish doings and thievish tricks, much less bring to light through thy dark, invisible presence the deeds of others which take place in darkness or secrecy; for God, Who sees all, Who hears all, Who ordains and grants all, to Whom all is known, and Who will reveal or conceal, and forgive, judge, punish, or reward all in His time and according to His divine will, has in His great wisdom retained such knowledge unto Himself."

Now when in this fashion I had given my bird's nest its honorable discharge, I also recalled the good things which I had had occasion to learn and to comprehend because of it since I had had it in my possession: namely, that that man walks in safety who keeps ever in mind the presence of God; who flees from bad company; who holds suspect people who appear to be charming; who never relies solely on himself; who spurns excessive drinking, so as to keep his wits about him; and who, for the rest, undertakes to learn something beneficial from all creatures, indeed from everything which happens to him, and from everything which he sees and hears, which does 
him honor, and might be of help in serving God and beneficial in attaining the salvation of his soul.

Because there happened to be a large anthill next to me, whose inhabitants were extremely busy gathering in all sorts of materialia, and particularly the twigs and straws of the torn-up bird's nest, I watched their bustling activity and unflagging labor with wonderment, and recalled Solomonis proverb, which goes: "Go to the ant, thou sluggard," etc. 10 Then I observed how one so sensibly made way for the other, how one helped the other to carry its burden, how they were all of one mind in furthering their labors, and so forth. From this I now gathered all manner of good lessons, and resolved henceforth to do a great number of good works. Henceforth I intended to work my fingers to the bone to support myself honestly and be a burden to no one. In the future I intended to yield to my neighbor, and not only gladly to give way to him, but in addition gladly to tolerate, out of Christian love, the burden of his shortcomings, and to help him bear his troubles, and with continual zeal to abide so steadfastly in this endeavor that the entire kingdom of the ants would have no cause to reproach me for the slightest thing on that great day on which all men's actions and transactions shall be examined, scrutinized, judged, rewarded, and punished; for now I well saw that to begin something and not complete it is no better than not to begin it at all, and therefore the most important thing for me at this time was that I learned to esteem Constancy.

But, $\mathrm{O}$ rare Virtue! At that time I was, to be sure, so engrossed in contemplating thee that I sat there for more than three hours with thee, and most firmly resolved to forever unite myself with thee, in indissoluble matrimony as it were; indeed, I should have persisted even longer in these speculations, had Fate not unexpectedly demonstrated to me that the world is devoted not to thee, but to thy archenemy, Inconstancy. Whether the frivolous character of so many 
different people, or the stars themselves, as some will have it, be the cause of this, no one knows.

For there came a pack of wolves which immediately interrupted my train of thought and frightened me all the more because it was neither January nor February, during which wild beasts of this sort are wont to foregather and to rut; therefore I abruptly left off these good thoughts about what I had resolved to do, and now devoted my thoughts solely to how I might save my life from these terrible visitors. To this end I climbed in the greatest terror up the trunk of a broken-off beech, which seemed to me to be the most suitable for this purpose, and after I had climbed up with slight effort, and now believed myself safe from the wolves, more and more of which were arriving, look you, another unexpected sight so frightened me that I indeed gave myself up for lost; for when I had climbed up into the beech, I espied two varmints which I took to be two frightful serpents. I thought to myself: If you climb back down again, you will end up in the jaws of the wolves, but if you stay up here, these $b a$ salisci 12 will strangle you. Neither the terror which possessed me nor my fear left me much time to reflect and make a choice, but rather, in order to do the safest thing, and to escape the supposed serpents as well as the wolves, I climbed up onto a limb, or branch, which had grown out of the side of the stump, or main trunk, and which had then grown straight up into the air. So there I crouched, high up, and saw what a multitude of wolves were, in whole battalions as it were, gathering there; and they not only surrounded me, but also occupied the entire area for a stone's throw away from me, so that I could well surmise that this orderly encirclement could not have come about in any natural way.

Straightway thereafter two men approached, of whom the one appeared to be a rich gentleman, but the other one, who was rather up in years, appeared to be, to judge by his ragged clothing, a vagrant 
runagate. They came up to where I had sat, and there the old man said to the other one: "Now then, milord! Now we are at the place where you, sir, may obtain either your treasure and lost money, or the means to make yourself invisible; and, sir, you should choose the one or the other quickly, before the propitious hour goes by." The distinguished looking gentleman answered: "I have more than enough money and property; therefore I herewith wish to relinquish and surrender the money I lost and reckon it to the treasures which lie hidden; anyone who finds it may keep it; but instead I accept in its place the jewel by means of which I shall be able to make myself invisible."

Hereupon they both sat down by the anthill, of which the old man took a handful and asked the other one whether he could still see him. When the other answered "Yes," he laid that handful down beside him and took another, asking again, as before, and continued to do this till finally he seized a handful which caused him to disappear instantly, and when he once more asked: "Do you see me, sir?" and the other answered "No," then he said: “Then, sir, hold open your mouchoir, and receive what you desire." The other obeyed, and as soon as the old man had put into the handkerchief the handful of twigs and straws from the nest which he had taken from the anthill, he too disappeared, and instead I saw the old man once more, which was strange and miraculous to behold.

Hereupon the old man told the other one to tie the things up carefully in his handkerchief, so that the precious piece which had the power should not be lost; this the other one did, although what he was doing could not be seen. Following that, he laid the tied-up handkerchief on the ground and tested the certainty of the effect several times, which was that then one could not see it, but instead could again see the one who had put it down. Now after they had thus amused themselves for a good while, and demonstrated sufficiently 
to me that the power of my erstwhile bird's nest was now, in another form, serving another master, the old man bade the other one to betake himself hence, and when I lifted my eyes, I perceived that all the wolves had also disappeared.

The old man, for his part, drew forth his divining rod to search for hidden treasure; he mumbled a few words while doing so, and sneaked about everywhere with it. I, however, climbed slowly down the branch, and perceived that what in my terror I had at first espied was not snakes, but rather two silken sausages full of gold, namely, the thousand double ducats which the Hopalongian hurdy-gurdy girl had stolen, 13 which golden snake ribs shimmered forth quite delightfully through the partly worn, partly torn material. I stuck it all in my satchel and watched the fellow with his divining rod, who finally found in a hollow tree a rather large nombre of sovereigns and some silverware, which he packed up, and with which he betook himself on his way. I, however, did not muck about there any longer, but rather made plans about how to invest my riches, and how to make happy once more and preserve the honor of the kind, friendly maiden whom, in her innocent sleep as it were, I had defiled and robbed of her virtue.

\section{*****}

This then, most highly honored and most gracious reader, is the histori which I wished to tell you about my bird's nest. If, now, you have learned from it what I wished to teach you, I am pleased; but I shall be much more pleased and happier, and it shall be much more useful to you and pleasing to God, if you endeavor to adhere to the precepts which I have been at pains to teach you. However, if you, contrary to my hopes, should be of such disposition that you have found in my story neither explicit nor implicit teachings, or have not paid any heed to them, this little work will have nevertheless 
diverted you in some other way, and, I hope, will have helped you pass the time just as well, and perhaps more profitably and better than if you had been reading Amadis.14 Should I now see that this book is well liked, then it shall constitute the first part of the Bird's Nest, and the other part, beginning with the anthill, shall follow shortly. Should anyone feel that he has been depicted in this book, then let him be silent and mend his ways, for that is the reason why I wrote it. If, however, your comrade has been portrayed in it, then rejoice that you are innocent, and think: How could Abel help it that his brother was a scoundrel! But also pray to God not only that $\mathrm{He}$ not allow you to fall, but also that He rescue your brother. This was my intent when I began this little book, and is still my intent, as I herewith now bring it to an

END. 



\section{Short References and Abbreviations used in the Notes}

Acerra philologica: Lauremberg, Peter. Acerra philologica... (cf. Section B)

Bächtold-Stäubli: Handwörterbuch des deutschen Aberglaubens. (cf. Section B)

Bolte: Johannes Pauli. Schimpf und Ernst. (cf. Section A)

Hohberg: Hohberg, Wolfgang Helmhard, Freiherr von. Georgica curiosa acta... (cf. Section B)

Könnecke: Könnecke, Gustav. Quellen und Forschungen zur Lebensgeschichte Grimmelshausens. (cf. Section B)

Koschlig: Koschlig, Manfred. Das Ingenium Grimmelshausens... (cf. Section B)

LV: Bibliothek des litterarischen Vereins in Stuttgart. Stuttgart: Literarischer Verein, $1843 \mathrm{ff}$.

Ndr: Neudrucke deutscher Litteraturwerke des XVI. und XVII. Jahrhunderts. Halle: Max Niemeyer Verlag, 1876 ff.

Scholte: Scholte, J. H. Zonagri Discurs von Waarsagern... (cf. Section B)

Scholte (Probleme): Scholte, J. H., Probleme der GrimmelshausenForschung... (cf. Section B)

Weydt: Weydt, Günther. Nachahmung und Schöpfung im Barock... (cf. Section B) 



\section{Notes: Title Page}

Michael Rechulin von Sehmsdorff: An anagram of one version of the author's name, Christoffel von Grimmelshausen. Könnecke (vol. I, p. 151) notes that the name may have been inspired by a real person, Michael Regulir, who is mentioned in city records of 1672 and 1674 of Gelnhausen, Grimmelshausen's place of birth; Könnecke presumes that Grimmelshausen as a child must have known this person, or a relative bearing the same name.

Monpelgart: variously spelled in the seventeenth century "Mömpelgart," "Mompelgard," and "Mompelgart," it is the German name of the French "Montbéliard," a town on the Alaine River in the Doubs district of France, bordering on Upper Alsatia. In Grimmelshausen's time the town and the surrounding county were part of the holdings of the ruling house of Württemberg, which had obtained it in the late fourteenth century through marriage. The same place of publication is given for Simplicissimus, and Scholte, in an essay in Der Simplicissimus und sein Dichter (Tübingen: Max Niemeyer Verlag, 1950), pp. $17 \mathrm{ff}$., found support for his theory that Simplicissimus was in fact a religious satire in disguise in the choice of Monpelgart, which was a stronghold of Protestantism in the sixteenth and seventeenth centuries and was ruled in Grimmelshausen's time by a then quite well known religious fanatic. Weydt, who rejects Scholte's theory, has pointed out (p. 199 f.) that in the late sixteenth and seventeenth centuries Montbéliard was well known as a publishing center for both French and German books and that the German versions of a number of very popular French romances-among them Honoré d'Urfés Astrée and the universally popular Amadis-were published there. Weydt suggests that Grimmelshausen chose Monpelgart as the fictitious place of publication for Simplicissimus because the town was linked in the German reader's mind with the popular romance.

Johann Fillion: also named as the publisher of Simplicissimus, which was actually put out by Wolf Eberhard Felssecker of Nuremberg. Scholte (Probleme, p. 70) noted that "Johann Fillion" is an anagram of "Johann Jon. Fil." (Johann Jon[athan] filius) - “i” and “j” were interchangable for anagrams-and might refer to Felssecker's son, whose 
name was Johann Jonathan. Koschlig (Grimmelshausen und seine Verleger, p. 74) agreed with Scholte and rejected a later theory that the German "Monpelgart Gedruckt bey Johann Fillion" is meant to be an anagram for "Leipcik undt Hall bey Georgio Frommann" (Frommann was an important publisher of the time). Weydt, on the other hand, asserts (p. 28) that "Fillion" is in fact French for "little son" and suggests (p. 199) that Grimmelshausen may have had in mind his own son, since Simplicissimus writes his Perpetual Calendar for his son. Whatever the case, the name, as noted in our introduction, is probably used here, as is "Monpelgart," to link The Wondrous Bird's Nest to Simplicissimus and profit from the latter's continuing popularity, for Koschlig (Grimmelshausen und seine Verleger, pp. 266 ff.) presents persuasive evidence that The Wondrous Bird's Nest was actually first published not by Felssecker but by Georg Andreas Dollhopf of Frankfurt, who was identified in the Easter Book Fair Catalog of 1675 as the publisher of The Wondrous Bird's Nest, Part II.

1672: the date is apparently correct. Koschlig (Grimmelshausen und seine Verleger, p. $266 \mathrm{f}$.) presumes that Grimmelshausen began work on the novel at the earliest in the beginning of 1672 . 


\section{Notes}

\section{CHAPTER 1}

1. this bird's nest...: See Heedless Hopalong, Chapters 23, 24, and 26.

2. Gyges: the shepherd Gyges found a ring which made him invisible whenever he turned the stone in it toward him; with its help he deposed the King of Lydia and married his queen. The story was told by Plato in The Republic (Book II, 359d - 360b) and was very well known in Grimmelshausen's time. Lauremberg recounted it in Acerra philologica (First Hundred Anecdotes, No. 49), and Garzoni mentioned it briefly in the Piazza universale, Discourse No. Eighty Five, "On Jewelers and Precious Stones," but Grimmelshausen could have come upon the Gyges legend in any number of other works.

3. the old chapbook about Fortunato...: Fortunatus, which first appeared in print in 1508, became one of the most popular German chapbooks. Its hero came into possession of a magic purse which always stayed full of coins and a magic cap which could cause him to be transported, the moment he wished it, to any place in the world.

4. mandrakes: the mandrake, called in German either Galgenmännlein (little gallowsman) or Alraune (the mandragora, a plant whose roots allegedly look somewhat like the legs of a human being), was thought by the superstitious to possess various kinds of magic powers. In The Mandrake (1673) Grimmelshausen gives the following description of it in language which is a delightful parody of those language reformers of his time, such as Jesaias Rompler von Löwenhalt, who wished to make radical changes in German orthography:

For (so peepl say), when an archtheef is hangd, that iz, one for whom steeling is innate, eethr becauz his mothr stole when she waz carrying hm, or at leest had the dezire to steel, and when he lets watr pass [when hanged on the gallows], thn sutch a mandrake, which is also called a mandragora, growz from it, whitch aftrwrds, at a certn time and with strange ceremonees, to be shure,... with the sacrifice of a black dog, who diez insted 
of the diggr, must be dug up. Then it iz washt in red wine, rapt in soft linen and silk cloth, whitch bath iz repeeted for hm evree Friday, and he iz put in a littl box, and evree night a coyn iz put in with $\mathrm{hm}$, for whitch one find $\mathrm{z}$ two coinz the next morning.

It was also believed that the mandrake could be obtained only by a pure virgin, but since the cry of the mandrake when it was pulled out of the earth was supposed to be fatal, it was necessary to tie a string to it and to a black dog, which, when it tried to follow its master, would pull up the mandrake and, of course, die at the sound of the mandrake's scream. Then the dog's owner could retrieve the mandrake without danger. Achim von Arnim (1781-1831) made extensive use of Grimmelshausen's The Mandrake in his short story Isabella of Egypt (1812).

5. thieves' thumbs: it was believed that the thumb cut from the hand of a thief hanging on the gallows brought good luck because of magic powers which it possessed. In The Mandrake Grimmelshausen relates the following story concerning a thief's thumb:

Of thieves' thumbs, since they are well-known things, I should remain silent, if I did not know a certain histori which occurred in my own homeland when I was yet a schoolboy. There lived there a widowed potter named Konrad Wiesel who became formally engaged to the daughter of Glöckner, a bookbinder, and because there was no doubt that the marriage would take place, she did not forbear to sell his earthenware at weekly market, as other potters' wives are wont to do. To this end her bridegroom gave her something wrapped in a little cloth, with the assurance that if she had it with her, then she would do good business and be quickly rid of her wares. The curious bride examined, and also showed the other potters' wives the thing, which she took to be a talisman, but found a thief's thumb on which the thumbnail was grown out a long way. That did it; and because tradesmen hate each other anyway, the noise of it grew all the louder. To be brief, the bridegroom was arrested and interrogated, but it was alleged by him that he had got the thumb on his wanderings, which thumb the hangman burned in the gaol, but for the nonce the potter was set free. Hereupon his fiancée no longer wished to keep him, and his pottery no longer sold as quickly as heretofore. Anyway, it was not long before he was again siezed and executed as a sorcerer, since among other things he confessed that he had been a corporal among the sorcerers and had once been ridiculed when he had arrived at the 
gathering place of these fiends-called "under the pines"-in naught save his short, ragged, everyday coat.

6. many a mountain...: a popular saying derived from Horace, Ars poetica, line 139: parturient montes, nascetur ridiculus mus.

\section{CHAPTER 2}

1. I untethered his horse...: an adventure concerning an invisible rider also occurs in Moscherosch' Philander von Sittewald, "Ala Mode Kehrauß" (Vol. I, pp. 600 ff.), in which Philander sees a riderless horse which he at first thinks has wings and a hat tied to the saddle. He then realizes that the wings are actually boots, but he can still see no rider, and when he grabs the reins and tries to mount the horse, he feels two hands gripping the saddle horn and is suddenly kicked in the side by one of the boots while at the same time a voice is heard from under the hat. Philander lets go of the reins, and the horse runs off.

2. baseylemons: corruption of baiser les mains (French: "kisses of the hand," "compliments"); the German corruption is Baslemanes.

3. Sir Pnnlss: Sir Penniless; following a seventeenth-century convention, Grimmelshausen omits the vowels in the squire's name, in German Drftgkt (i.e. Dürftigkeit: "neediness," "impoverishment").

4. bluemorn: corruption of bleu mourant (French: "pale blue"); the German corruption is plümerant.

5. dear cousin: the form of address does not necessarily mean that they are related, for all members of the nobility addressed each other in thus fashion.

6. the falling sickness: epilepsy.

7. prodigal Cleopatra...: Cleopatra, after having been lavishly entertained by Antony, wagered him that she could dine many times more expensively, and to win her wager she gave a dinner at which, when Antony teased her about her boast, she took a priceless pearl, dissolved it in vinegar, and drank it, thus winning the wager. The anecdote was well known at Grimmelshausen's time and is recounted, for example, in Lauremberg's Acerra philologica (First Hundred Anecdotes, No. 32).

8. Jochem: actually Joachim, a type of wine and brandy. 


\section{CHAPTER 3}

1. Candia...: the capital of Crete, which was under Venetian administration; it was besieged by the Turks in 1648 and finally fell to them in 1669. For Hopalong's misadventures during the last months of the siege, see Heedless Hopalong, Chapter 25.

2. a mixture of flour...: as Scholte, Zonagri Discurs (p. 152 f.), points out, this passage is borrowed nearly verbatim from Garzoni's Piazza universale (p. 449), Discourse No. Seventy One, "On Beggars.”

3. then say "Forgive us our debts...: in the German the old crone's instructions concern the beginning of the Lord's Prayer, which was Pater noster in the Catholic church, Vater unser in the Lutheran, but Unser Vater in the Calvinist. No such distinction is made in the Lord's Prayer in English, so a similar instance of variance in the protestant versions was substituted. Grimmelshausen mentions the same practice in The TopsyTurvy World where the narrator encounters in hell a beggar who boasts: "so well did I understand churches that I was able straightway to determine by the look of them, even if only by their towers, whether a town was Catholic, Lutheran, or Calvinist, so as either to extend the Lord's Prayer, or to say after it the Ave Maria too;...”

4. prof-eat-ion: the pun in German is Profressium for Profession (fressen: "to eat like an animal").

5. tirones: recruits; i.e. lowest rank of enlisted men.

\section{CHAPTER 4}

1. agnus dei: Lamb of God, here referring to medallions with the Lamb of God on them which were thought to be efficacious in driving out devils.

2. horas: prayers (from horas, i.e. hours, the times of day specified for prayer by the Church, such as matins, vespers, etc.)

3. like that woman...: the allusion is to Boccaccio's Decameron, Ninth Day, Second Tale. An abbess arises in haste and in the dark to catch one of her nuns lovemaking, but thinking to cover her head with her coif, she puts on instead the breeches of the priest with whom she has been lying. She is harshly reprimanding the nun for her misbehavior when the nun notices the abbess' remarkable headdress and makes her aware of it, whereupon the abbess changes her tune and says it is impossible to withstand the prickings of the flesh. The anecdote became very well known in 
Germany; Kurz (vol. III, p. 488) points out that Christoph Lehmann (1570-1638) in his Florilegium politicum, 2. Theil (1641), p. 856, includes as a popular saying "We are all prey to human frailty, says milady the abbess." Grimmelshausen suppresses the fact that the two women were members of a Catholic order, perhaps so as not to give offense to his fellow Catholics.

4. Ambrosius Praisewater's hymnal: Ambrosius Lobwasser (1515-1585) published Psalmen nach Frantzösischer Melodey und relnen Art in 1574, and it soon became the standard hymnal of the Calvinist church. It was necessary to render his name into English in order to preserve the play on words involving wine and water.

5. Tales Merry and Grave: Schimpf und Ernst, a collection of tales and anecdotes made by the Franciscan monk from Alsatia Johannes Pauli (1450/54-after 1522), first appeared in 1522 and was repeatedly republished and expanded. The tale about the little girl and the priest is Anecdote No. 296 ( $L V$, vol. 85, p. 192; Bolte, vol. I, p. 186).

6. In Switzerland...: The story may have been inspired by, or be a variant of Schimpf und Ernst, Anecdote Nos. 768 and 849 (Bolte, vol. II, p. 48 and p. 89 f.), in which fun is made of simple Swiss peasants who are completely ignorant of religion and who, when sent to church for the first time at Easter, misconstrue what they see and hear. In Anecdote No. 849 the peasant lad, after listening to the priest's account of the Passion of Christ, asks how long ago all this happened, and when told that it was "nigh on to fifteen hundred years ago according to Holy Scripture," the boy is astounded, particularly since his father, a military hero dead barely forty years, has been quite forgotten. The ultimate source of the two anecdotes is probably Heinrich Bebel's Facetiae, Book II, Chapters 77 and 78; "De quodam Suitensi" and "De alio" respectively ( $L V$, vol. 276, p. 71 f.).

7. Dr. Schupp's Friend in Need: Freund in der Noht (1657), by Johann Balthasar Schupp (1610-1661). The anecdote referred to concerns a nobleman and a clergyman who is always attempting to demonstrate how learned he is. "Finally the nobleman was asked by the mayor of one of his villages to be godfather to the latter's child. And in this country it is the custom that a prospective godfather who as yet has no wife must be examined by the pastor to see whether he understands the catechismum. Now because this nobleman had no wife as yet, the pastor went to him and wished to examine him from the catechismo. But he surely did not wish to treat him like a common peasant lad and ask him from the catechismo 'Art thou a Christian?' but 


\section{NOTES}

rather he wished to treat him politely and said: 'Squire, what are you?' The nobleman answered: 'Parson George, I am a fool.' 'Oh!' said the pastor, 'What is this? I asked what you believe.' The nobleman answered: 'Parson George, I believe that you are just as much a fool as I am. 'Oh! Oh!' said the parson. 'How can you say such a thing?' 'Yes, yes', answered the nobleman, 'Parson George, the real fools are those who do not wish to admit it.' ( $N d r$, vol. 9, p. 28 f.)

8. red beard...: Grimmelshausen also links the red beard and Judas in The War of the Beards (1673), in which the fictitious narrator notes that Simplicissimus has reproached him for having a beard the color of that of Judas; the narrator insists that his beard is really "the color of gold."

9. Schttrwlt: Schutterwald, a village in the Black Forest in the Offenburg district.

10. that woman who could not be absolved of her sins...: the anecdote, included in the 1545 edition of Pauli's Schimpf und Ernst (Anecdote No. 795, Bolte, vol. II, p. 60), is based on Bebel's Facetiae, Book II, Chapter 62, "De calliditate mulierum histora vera" ( $L V$, vol. 276, p. 66 f.), Hans Sachs also recounts it under the title "Das Weib mit dem Pöpelmann.”

11. not a divine but a di-aqua: The German play on words involves the words Kande (pitcher for wine), Krug (pitcher for water), and Prädikant (protestant clergyman). The clergyman ignores the request that the Prädikanten enter, claiming that he is a Prädikrug.

\section{CHAPTER 5}

1. praelegatum: pre-legacy, i.e., a legacy payable upon demand to the heir(s) before the distribution of the testator's estate.

2. stinging nettles they give to crayfish: Hohberg, vol. 2, p. 614, writes: "If you wish to keep them [crayfish] alive for a long time, give them stinging nettles, especially young ones.... If you are carrying crayfish overland, then put fresh green grass, or, as I have said, stinging nettles in the hampers with them."

\section{CHAPTER 6}

1. gramercies: salutations. 
2. St. John's toast: the toast traditionally drunk before taking leave of someone, allegedly so called because the wine was consecrated on St. John's Day.

\section{CHAPTER 7}

1. wine watering: literary works of Grimmelshausen's time repeatedly deride innkeepers for adulterating their wine and brandy in order to cheat their guests; this very practice proves disastrous for both Hopalong and his first wife (see Heedless Hopalong, Chapter 21). See also The Wondrous Bird's Nest, Chapter 13.

2. the devil's own mounts: In Topsy-Turvy World Grimmelshausen treats "the devil's own mounts" in greater detail in the scene in which the narrator comes upon the devil's stables and asks his guide about the many horses standing there in burning straw: "he answered that on earth these horses were women who let themselves be deluded and seduced by the lust and prickings of the flesh so that, forgetful of themselves, like the horse and the donkey, in which there is no understanding, they indulged in lechery, but mainly those who vowed to the highest God to remain forever chaste, but yielded to their lust, and for this purpose let themselves be bedded in the hay, as it were; therefore they are used by our folk [the devils], since they are comfortable to ride, as mounts when they perchance have a matter to attend to on earth which, either for the sake of splendor or of deceit, must needs be accomplished in a fine and reputable fashion, and, of course, on horseback;...”

3. Hippocras: a wine flavored with spices, so called because of its Latin name, vinum Hippocraticum, which it was given because the wine was filtered through a "Hippocrates bag."

4. Malvoisier: malmsey, i.e., a strong sweet wine; it originally came from Monemvasia (i.e., Napoli di Malvosia) in Morea.

\section{CHAPTER 8}

1. tractatus Isaaci Peyrii de Prae-Adamitis: in 1655 Isaac de La Peyrère (1594-1676), a Calvinist from Bordeaux, published anonymously two works in which he attempted to prove that human beings must have existed on earth before Adam: Systematheologicum ex Praeadamitarum hypothesi and Praeadamitae. The Inquisition was understandably perturbed by these controversial works and had their author 
imprisoned for a time. La Peyrère apparently saved his life by journeying to Rome, recanting, and converting to Catholicism. His views were nevertheless much debated throughout Europe during the years during which Grimmelshausen was writing his Simplician works.

2. the lies of the Egyptians and other heathens: La Peyrère cited in support of his thesis the works of Plato, Herodotus, Diodorus Siculus Strabo, and others. One of his most emphasized points was that the Egyptians, Phoenicians, Chaldeans, and Chinese, as well as the peoples of India, have records far older than any of the writings of the Jews. Cf. David Rice McKee, "Isaac de La Peyrère, a Precursor of Eighteenth-Century Critical Deists," PMLA 59 (1944), 456 ff.

3. old heathen philosophers like Epicuro...: the philosophers in question, in the order in which listed, are: Epicurus (341-270 BC), founder of the Epicurean school; Democritus (400-c. 370 BC), one of the earliest atomists; Anaximander (C. 610-c. 546 BC), scientist, philosopher, and friend and pupil of Thales; Thales of Miletus (flourished c. $580 \mathrm{BC}$ ), natural philosopher and founder of the Ionian school; Metrodorus of Lampsacus (c. 330-277 BC), a pupil of Epicurus; Anaximenes (flourished 545 BC), of the Ionian school; Aristocles of Messana (second century AD), a peripatetic; Archelaus of Miletus (fifth century BC), member of the Ionian school, pupil of Anaxagoras and allegedly the teacher of Socrates; Xenophanes of Colophon (c. 570-500 BC); Leucippus (fifth century BC), an atomist; Diogenes of Apollonia (flourished second half of the fifth century BC), a follower of Anaximenes (not to be confused with the more famous Diogenes of Sinope); and Anaxarchus (flourished c. 320 BC), a follower of Democritus. Grimmelshausen, of course, had no firsthand knowledge of these philosophers, most of whom advanced theories concerning the nature and origin of the world. From which of the many polyhistorical works of his time Grimmelshausen copied this totally unorganized list has not been determined.

4. like Luciano...: Lucian (c. 180-120 AD), the Greek rhetorician and satirist, described his alleged week-long stay on the moon and the peculiarities of the "moonites" in a satire entitled "A True Story," Book I, Chapter $22 \mathrm{ff}$.

5. He extirpated the Sodomites...: Genesis 19:24-25.

6. the Jews, to this very day...: the allusion is to the commandments in Deuteronomy 22:9-11: "Thou shalt not sew thy vineyard with divers seeds; lest the fruit of thy seed which thou hast sown, and the fruit of thy vineyard, be defiled. Thou shalt not plow 
with an ox and an ass together. Thou shalt not wear a garment of divers sorts, as of woolen and linen together."

7. Wise Ecclesiasticus ...: the passage is from Ecclesiasticus 43:27-32. Grimmelshausen omits the last exhortation of 43:30: "and when ye exalt Him, put forth all your strength and be not weary; for ye can never go far enough."

8. Thomas à Kempis...: Thomas Hämmerlein (1380-1471), called Thomas à Kempis because he was born in Kempen, wrote Imitatio Christi, one of the most popular religious tracts of all time. Grimmelshausen apparently is alluding to Book I, Chapter 1, "Of the Imitation of Christ, and Contempt of all the Vanities of the World." In 1670, at about the time when Grimmelshausen may have been writing The Wondrous Bird's Nest, a paraphrase of the Imitatio Christi appeared in German under the title Geistlicher gantz trostreicher Calender.... Munich: J. Jäcklin.

9. Paracelsus...: Theophrastus Paracelsus Bombast von Hohenheim (1493-1541), who was a renowned humanist, chemist, doctor of medicine, and philosopher, wrote a book on nature sprites entitled Liber de nymphis, sylphis, pygmaeis et salamandris et de caeteris spiritibus. The work, despite its Latin title, was written in German; an English translation of it appeared in Four Treatises of Theophrastus von Hohenheim called Paracelsus, ed. Henry E. Sigerist, Baltimore: The Johns Hopkins Press, 1941.

10. Heinrich Kornmann ...: Heinrich Kornmann (died c. 1626). The work cited is De Monte Veneris, d. i. Beschreibung der Göttin Venus, ihrer Königlichen Wohnung vnd Gesellschaft, wie auch von den Wasser-, Erde-, Luft-, vnd Feuermenschen, Frankfurt, 1614. Klaus Haberkamm, Sensus Astrologicus, p. 169, asserts that the fact that Grimmelshausen puts after the Latin words for the spirits equivalent German ones which are similar to those found in Kornmann's title represents strong proof that Grimmelshausen knew Kornmann's work and the remarks about sensus astrologicus in the twenty-first chapter of it. It is quite possible, however, that Grimmelshausen had no firsthand knowledge of either Kornmann's or Paracelsus' work, for the passage here is a reworking of the following remarks by Martin Zeiller in his translation of Francois Rosset's Theatrum tragicum, which is also probably the source of the affair between the hurdy-gurdy girl and the baker in Heedless Hopalong (cf. Chapter 26, footnote 2): "Theophrastus Paracelsus in lib. de Nymphis, Sylphis, Pygmaeis \& Salamandris \&c. - Item, Henricus Kornmann in Monte Veneris account and reckon these creatures [water sprites like Melusina] to the four types of spirit-humans, as 
they call them, and allege that such Nymphae or water sprites, Pygmaei or mountain gnomes, sylphs or Sylvestres and air sprites, and the salamanders or Vulcani and fire sprites were created by God in all four elements in the form of Adam, with blood, flesh, and bones, and that they give birth, and also speak, eat, drink, and wander abroad:..." (Theatrum tragicum, p. 19).

11. Weydt, p. $101 \mathrm{ff}$., suggests that this episode may have been inspired by an anecdote entitled "Die glückseligen Almosen" which Georg Philipp Harsdörffer included in his Der Große Schau-Platz / Lust- vnd Lehrreicher Geschichte.

12. manes...: manes are spirits of the dead, lemures spirits of the unburied dead who unless exorcized haunt the living, coelites the spirits of heaven, and inferi the spirits of hell.

\section{CHAPTER 9}

1. any fifty-year-old butcher: an allusion to the butcher feeling a calf before purchasing it. The earliest example of the image is found in Meister Altswert's "Der Kittel," in which the following lines appear in a description of the lewd way in which men treat women: "Umb das grifft er hin und her, / Ich wen er si ein metzger, / ... Ein metziger hat den sitten, / Das kalb begrifft er im schlitten, ...” ( $L V$, vol 21, p. 54 f.), which, somewhat freely rendered, is: "Here and there he feels the maid, / You'd think he was a butcher by trade, / ... A butcher's ways are very crass, / He'll always feel a young calf's ass." The image also appears as a simile in "Ein spil von der Yasnacht" ( $L V$, vol. 28, p. 381): "Another [woman] is felt like a calf."

2. the scene, of course, is a variant of the popular anecdote about "putting the devil in hell." Cf., for example, Boccaccio's Decameron, Third Day, Tenth Tale.

\section{CHAPTER 10}

1. classical style: Renaissance style is meant.

2. tormae solis: actually torna solis, red-dyed pieces of cloth of various kinds with which water, wine, and fruits were colored; the ladies of the time used them much as they use rouge today. The name allegedly derives from the heliotrope, whose fruit was used in preparing the pieces of cloth (the heliotrope, as the name implies, was "turned toward the sun"). 
3. oleum talci: a facial cream made of tallow.

4. Pickle Herring...: the clown in seventeenth-century low comedies; he sometimes amused audiences by twisting his hat into various shapes. Grimmelshausen calls him not Hanswurst, the normal German name, but Hans Supp, the German for Jean Potage, the clown of French vulgar comedy. Moscherosch describes the actions of the clown in "Ala Mode Kehrauß" (Moscherosch, vol. I, p. 639) when he has his hero Philander depict himself as follows: "I am whatever one wishes me to be, and in these wretched times I have been obliged to ... let Hanswurst's hats be twisted, turned, flattened, pulled out, and pressed in all kinds of ways."

5. beautiful Psyche...: the story of the love of Cupid and Psyche was told by Apuleius (c. 123-c. $180 \mathrm{AD}$ ) in The Golden Ass; the passage referred to here is found at the beginning of Book $\mathrm{V}$.

6. the rich man in Luke 16: Luke 16:19: "There was a certain rich man, which was clothed in purple and fine linen, and fared sumptuously every day." Grimmelshausen patterned his contrasting portrayal of rich and poor in this and the next chapter on the story of the rich man and Lazarus.

7. olla podrida: a stew made of one or more meats and several vegetables.

8. Spanish bread; a rich, flaky bread. Hohberg (vol. III, part 3, p. 169) gives the following recipe for it: "Beat well three eggs and three egg yolks in a bowl, stir in a half pound of sifted sugar, then stir in a half pound of fine flour and one ounce of finely ground almonds in rosewater. When the dough is nice and smooth, grease a bread pan with butter, fill it half full of dough, put in an oven and let bake slowly."

9. Hippocras...good red Jochem: See Chapter 7, note 3, and Chapter 2, note 8.

\section{CHAPTER 11}

1. He howled...: the comparison of various people wailing to the various singing voices is not original with Grimmelshausen. In Der deutsche Lucianus (1659) Johann Balthasar Schupp, for example, compares a lamenting family of mother, daughter, and father to a trio composed of an alto, a soprano, and a bass respectively. ( $N d r$, vols. 225-27, p. 12).

2. poor Lazari: see Luke 16:19-31. 
3. "hexecutioners": the German word for those who execute a judgment of a court was Exequierer; in his righteous anger the father refers to them as Hexengierer (Hexe: "witch" and Gierer; "greedy persons").

4. Perception deceives: the motto in German is Der Wahn betreügt. Wahn has a number of connotations, ranging from "erroneous opinion" to "folly" and "madness"; Grimmelshausen is probably using it in the motto to express that predisposition of the human mind to distort perceptions or misinterpret them which so preoccupied the Baroque. Weydt, p. 67, points out that this motto occurs in such laconic form in a marginal notation to Anecdote No. 220 in Harsdörffer's Frauenzimmer-Gesprächspiele. It should also be noted that Georg Henisch, in his Teutsche Sprach und Weisheit (Augsburg, 1616), p. 352 lists as a proverb Manchen betreugt sein Wahn, and Grimm's Deutsches Wörterbuch, vol. 13, p. 615, identifies a similar motto, Der Wahn trügt, as proverbial. Scholte, p. 246, pointed out that the motto does in fact appear on eighteen of the twenty copper etchings in the 1671 edition of Simplicissimus and that only the two meant to illustrate the so-called "Calender Continuations" (Continuatio 2 and 3) do not bear it. Koschlig, p. 196 ff., takes this to be strong evidence that the two "Calender continuations" were not the work of Grimmelshausen but rather of a hack hired by his son.

5. he so often...: Koschlig, p. 216, gives an interesting but rather farfetched reading of this passage. The pronoun "he" in the parenthetical statement, he contends, refers "unequivocally to 'his son' and not to 'old Simplicissimus'...," and since Grimmelshausen, according to Koschlig, occasionally attacked the author Johann Beer by calling him Harsdörffer's son, the parenthetical remark is a veiled jab at Beer for his predilection for using Harsdörffer's phrase Der Wahn betreugt. Koschlig was evidently insensitive to Grimmelshausen's tendency to play fast and loose with pronoun references (to the near despair of his translators on occasion).

\section{CHAPTER 12}

1. a fellow... with a cow in tow: the following episode was probably inspired by Anecdote No. 710 in Pauli's Schimpf und Ernst (Bolte, vol. I, pp. 16-18); A scoundrel steals an innkeeper's cow, takes it part of the way to Cologne, ties it up in a thicket, and returns to the inn. The next day, as he and the innkeeper are walking to Cologne, the thief, on the pretext of collecting a debt in a nearby village, retrieves the cow, which he claims to have taken in lieu of the money owed him. Because the thief does not 
wish to be seen in Cologne, where he is wanted for other crimes, he persuades the innkeeper to sell the cow for him and bring the money to an inn which he specifies. This the innkeeper does, and when the two meet at the inn, the thief insists that he be permitted to treat the cow's real owner to a meal, for which purpose he borrows two pewter platters and then, because he fears he may be recognized by his clothes, a cloak, allegedly to hide the roast chickens which he is going to fetch for the meal. The thief, of course, never returns. The anecdote was a popular one and was retold in various ways by a number of other German authors with whose works Grimmelshausen may have been acquainted. Cf. Johannes Bolte, "Die ältesten Fassungen des Schwankes vom Kuhdiebe," Archiv für das Studium der neueren Sprachen und Literaturen, vol. 113 [N. F. vol 13] (1904), pp. 17-30, particularly p. 27 f.

2. podograst: the German word used is Cyprianer ("man from Cyprus"), which is a play on the word Zipperlein ("podagra" or "gout"); inasmuch as the sexual morality of the natives of Cyprus was, in the view of seventeenth-century Europeans, extremely lax (Cf. The Runagate Courage, Chapter 19, Footnote 2), we have chosen to invent a word which should bring both podagra and certain sexual practices to mind.

3. salva guardia: guard duty.

4. Peter Simon: a wine, allegedly named after the Dutchman who introduced into Spain the Rhenish grapes from which the wine was made.

5. Striegau: a city in Silesia noted for its beer.

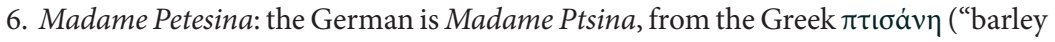
water," i.e. beer). Petesina is evidently meant to be a play on Peter Simon.

7. pile of excrement...: according to popular superstition among criminals, a thief could protect himself while committing a robbery by defecating at the scene of the crime. His fecal matter, it was thought, served as a guard or watchman, and as long as it remained warm, no one in the place he was robbing could awaken (cf. BächtoldStäubli, vol II, p. 234). The persistence of this belief is indicated by the fact that the same protective measure is taken by twentieth-century thieves in Alfred Döblin's Berlin Alexanderplatz. The "light" or "sleep-flame" which the two thieves use and for which the narrator knows no name was generally called a "thief's candle" or "thief's light" and was believed either to indicate whether everyone in the house was asleep 
or to put all the occupants to sleep or to make the bearer invisible (!) or to open all locks (cf. Bächtold-Stäubli, vol. II, p. 229).

8. they sent for the hangman...: only the hangman, who was deemed not to be honorable, was permitted to touch the body of a dead criminal.

9. soften a Hamburg zwieback in it: apparently this refers to the eating of zwieback (and other food) while drinking alcoholic beverages so as to prevent or inhibit intoxication.

\section{CHAPTER 13}

1. worse than a Jew: Grimmelshausen shared the prejudices of his age, but he was on the whole more tolerant and less anti-Semitic than most of his contemporaries.

2. sheepcote: at Grimmelshausen's time the word Schäferei meant both "sheepcote" and "pastoral romance," a form of the novel popular among the literate nobility and the bourgeois intelligentsia. That the behavior of the shepherd and his wife is in striking contrast to that of the highly idealized shepherds and shepherdesses of the pastoral novel would not have been lost on Grimmelshausen's readers.

3. honest Colerum...Oeconomia: Johannes Colerius (c. 1570-1639) published his Calendarium perpetuum in 1592 and his Opus oeconomicum between 1593 and 1603; the two works were then combined and published under the title Oeconomia Rural is et Domestica, Darinn das gantz Ampt aller trewer Hauß-Vätter, Hauß-Mütter, beständiges und allgemeines Hauß-Buch, vom Hauß-halten, Wein-Acker-Gärten-Blumen und Feldbau begriffen.... The Oeconomia went through fourteen editions by 1700 . Koschlig, pp. 121-58, examines in detail Colerius' importance for Grimmelshausen's professional life as a steward and as a writer.

4. But when the sky cleared...: the florid style of this description is probably a satire on the learned novelists of the time for whom Grimmelshausen apparently felt some envy but very little respect. In their works highly poetic descriptions of daybreak abound; for example, in Philipp von Zesen's Assenat, which Simplicissimus discusses below, Books 5 and 6 begin with brief but florid descriptions of the dawn.

5. a delicious ham...shoe...: the same motif occurs in Novella No. 98 of Il Trecentonovelle by Franco Sacchetti (c. 1330-c. 1400), but there a hat is substituted for the meat boiling in the pot. 


\section{CHAPTER 14}

1. St. Crispinus: the patron saint of cobblers; according to legend he stole leather from rich tanners and made from it shoes which he gave away to the poor.

2. for making shoes for old ladies to live in: the German, which literally is "for making shoes for the geese," refers to a popular German nursery rhyme for which there is no English equivalent: "Eia popeia was raschelt im Stroh? / Es sind die klein Gänschen, die haben kein Schuh. / Der Schuster hat Leder, kein Leisten dazu, / Drum kann er auch machen den Gänschen kein Schuh.” In English; “My, oh my! what's that in the mews? / 'Tis all the poor goslings without any shoes. / The cobbler has leather but no last to use, / So none of the goslings can have any shoes."

3. for seventeen weeks: Grimmelshausen seems to have had a predilection for the number "seventeen." As Koschlig, p. 31 f., has pointed out, it not only occurs twice in The Wondrous Bird's Nest, but also in Simplicissimus III, 7 and VI, 13, in The TopsyTurvy World, and in other of his works (cf. Johann Kienast, J. J. Chr. von Grimmelshausen. “Das Vogelnest I. und II., University of Vienna Dissertation, 1937, p. 53). Weydt, p. 298, suggests that the reason may be that it was Grimmelshausen's day of birth, which Weydt believes must have been March 17, 1621.

4. horas: see Chapter 4, note 2 .

5. chief cellarer: the chief administrator of all the property, animals, and produce of a monastery.

6. Battum: Battus, in Greek mythology, was a shepherd who promised to to keep silent about Mercury's theft of some cattle from Apollo's herd; when he broke his word and told all, he was turned into a stone (Ovid, Metamorphoses II, lines 687 ff.). He thus became the symbol for a person who carries tales harmful to others. Grimmelshausen uses Battus in this sense both in the introduction to The Satirical Pilgrim and in the Jupiter episode in Simplicissimus III, 5, both of which are based on the introductory essays in Garzoni's Piazza universale, in which Battus launches a tirade against Garzoni.

\section{CHAPTER 15}

1. Master Urian: the devil. 
2. a crime which must have been familiar to persons in and around Strasbourg may have inspired Grimmelshausen to have the murderer caught after robbing a draper. At the Mahlberg fair on 25 November 1664 a draper from Strasbourg named N. Fuchs was robbed of several bales of cloth, and his discovery of his wares in Offenburg led to the arrest of one Hans Wurtz (alias Hans Fellinger) on 12 December. The thief confessed and was executed on 16 January 1665-see Arthur Bechtold, Grimmelshausen und seine Zelt (Munich: Musarion Verlag, 1919) pp. 70-73. Grimmelshausen gives more details about the disappearance of the body from the gallows in The Mandrake: "About three years ago on Good Friday eve a thief's body-hide and hair, clothes, chains, and all-was stolen from the gallows of an Imperial city, and doubtless by dissolute folk...." The body, of course, could hardly have been that of Hans Wurtz, since the theft occurred in 1670 .

3. Master Cheatum: in German the innkeeper's name is Schrepfeisen, the term for a cupping instrument used in bleeding patients; schröpfen, the Modern German form, like its English equivalent "to bleed," soon came to mean "to fleece," "to cheat."

4. the prelate at N. : Baroque convention was to use N. or N. N. whenever proper names, for whatever reason, were being suppressed.

5. horoscope: Grimmelshausen's interest in and ambivalent attitude toward prophecy through use of the stars are attested to by the lengthy discourses in his Perpetual Calendar (which he borrowed, for the most part verbatim, from Garzoni and Indagine).

6. Thomas à Kempis: see Chapter 8, note 8 .

7. Asenath and Chaste Joseph: Der keusche Joseph (1666) was Grimmelshausen's treatment of the Joseph story. Four years after it appeared, Philipp von Zesen (16191689) published a novel on the same theme entitled Asenath (Assenat; das ist Derselben / und des Josefs Heillge Stahts- Lieb- und Lebensgeschicht... Zu Amsterdam... Kristian von Hagen...1670....).

8. Asenath and Joseph are said to have been man and wife: Genesis 41:50: "And unto Joseph were born two sons before the years of famine came, which Asenath the daughter of Potipherah priest of On bore unto him."

9. cuffs aplenty: in the 185 pages of "Concise Notes" which Zesen appended to his 334-page novel, he refers to Grimmelshausen (as Samuel Greiffensohn, under which 
pseudonym Chaste Joseph appeared) ten times, but only five of the references can be construed as "cuffs."

10. the trick which Simplicissimus plays on Cheatum was probably inspired by Anecdote No. 371 in Pauli's Schimpf und Ernst (LV, vol. 85, p. 227; Bolte, vol I, p. 223): "One time a guest came into an inn and ordered a measure of wine brought. The servant put the measure down before him, took a glass and rinsed it. Meanwhile the guest guzzled down the measure of wine. When the servant came with the glass and went to pour, there was no wine there, and he said: 'Where did the wine go?' Then the guest said; 'Do you serve your guests empty pitchers?' So the servant brought another measure of wine." Simplicissimus, of course, is too honorable to take such advantage of Cheatum.

11. Zoilum...Homerus: Zoilus was a Greek rhetorician of the third century B. C. whose harsh criticism of Homer (and Plato too) caused his name to become a symbol for the carping, niggling critic. Like Battus, he figures prominently in the Introduction to The Satirical Pilgrim and the Jupiter episode in Simplicissimus III, 5. Grimmelshausen's source of information was doubtless Garzoni’s introduction.

12. The History of Asenath...: one of Zesen's main sources for his Asenath was Die Histori Aßnath / Von Josephs Verkauffung vnd wieder Erledigung auß dem Kerker. Von seinem Heurath vnd Außgang, which was included in The Last Wills and Testaments of the Twelve Patriarchs (see below, note 17).

13. like the crow of Horatii: the allusion is to the crow which adorned itself with the plumage of other birds, an anecdote to which Horace refers in his Epistles, Book I, Epistle 3, $11.18 \mathrm{ff}$. (not Book II, Epistle 5, 1. 18, as Kurz and later annotators who unquestioningly copy Kurz' note assert-there is, of course, no Epistle 5 in Book II). Horace urges his friend Celsus Albinovanus to rely on his own genius and refrain from copying passages from the works of others, "lest, if the birds some day perchance come to take back their plumage, the poor crow, stripped of his stolen colors, arouse laughter." Grimmelshausen almost certainly had no firsthand knowledge of the passage, but rather was acquainted with "Horace's crow" from Garzoni. In the introduction to the Piazza universale (p. 3) Momus accuses Garzoni of stealing most of what he has written from other authors: "And even if we grant that the materia is amusing, and worthwhile that one write about it, that it is curious, and also worthy of all honor, it nevertheless does the authore slight honor that, by his own admission 
and through his list of sources, he is guilty of so many and manifold thefts, and it is indeed to be feared that if every one demanded the return of what was his, in the end we would see him [Garzoni], like the crow of Horatii, standing bare and naked before the whole world, an object of scorn and contempt."

14. "Imaus".... "Conchares"... "Alrian"...: in Zesen's notes to Asenath (pp. 394-95) he mentions that the name of the pharoah who was reigning when Joseph was brought to Egypt is given by an Arabian source as "Alrian," and by other sources as "Konchares"; Zesen then goes on to criticize Grimmelshausen: "Samuel Greiffensohn [Grimmelshausen], to be sure, does not give him any name other than Pharoah. But his son he calls, on page 138 in the history of Joseph, whence I know not, "Imaus," and writes that this Imaus, after the death of his father, was just about to be crowned king when he had Joseph fetched from prison to interpret his dreams, which conflicts with all historians whom I have read, also with the History of Asenath, and even with The Last Will and Testament of Joseph."

15. The Last Will and Testament of Joseph: another of Zesen's main sources for Asenath; it was one of The Last Wills and Testaments of the Twelve Patriarchs (see below, note 17).

16. "Nephrem" and "Tomestor": Zesen, in his notes to Asenath (p. 395) writes concerning the name of the pharoah: "But because most sources, including The History of Asenath, call the pharoah who ruled when Joseph was sold 'Nefrem', or 'Nefrem Tomestor,' we have decided to follow the majority and will keep the name 'Nefrem' in our story rather than any of the others."

17. The Last Wills and Testaments of the Twelve Patriarchs: Testament und Abschrifft der Zwölf Patriarchen, 1554 [recta 1664] was modeled on Genesis 49. Just as Jacob on his death bed passes on his teachings to his sons, in the Twelve Patriarchs each of his twelve sons on his deathbed instructs, his offspring, and in so doing reminisces about his own life.

18. That these two works should have been kept secret...: in his preface (unpaginated) to Asenath Zesen writes concerning The History of Asenath and The Last Wills and Testaments of the Twelve Patriarchs: "These two latter works the Jews-out of envy, it has been written-kept secret for a long time." Zesen goes on to relate how the Greeks got hold of the works and translated them into Greek, which version Robert the Second, Bishop of Lincolnshire, rendered into Latin, from which the German translations were then made. 
19. before Ezra's time...: Grimmelshausen's source was Garzoni’s Discourse No. Twenty Nine, “On Cabalists” (p. 197/198). Sixtus IV was pope from 1471 to 1484.

20. was composed long after Joseph's time: Grimmelshausen's surmise is correct.

21. Holy Scripture: the Bible does indeed make clear that the man who bought Joseph as a slave in Egypt and the father of Asenath are not one and the same person, as Zesen believed and made them in his Asenath. Cf. Genesis 39:1 ("And Joseph was brought down to Egypt; and Potiphar, an officer of Pharoah, captain of the guard, an Egyptian, bought him...") and Genesis 41:50 (see above, note 8).

22. the Jewish historian Josephus: Flavius Josephus (c. 37 - c. 100 A. D.); his Jewish Antiquities was one of the works Grimmelshausen used in writing his Chaste Joseph.

23. the opinion of enlightened Augustini: Zesen's note concerning the identity of Potiphar (p. 408) supplied Grimmelshausen with the information concerning St. Augustine: "On the other hand, Augustinus claims that Joseph's father-in-law was another Potiphar other than the one who bought him. And of the same opinion are Lipomatus, Oleaster, Pererius, as well as the oft-mentioned S. Greiffensohn, and Vossius...;"

24. the learned Vossio: Gerhard Johann Vossius (1577-1649) whose De Theologia gentili et physiologia christiana; sive de origine ac progressu idolotriae (1641) Zesen cites repeatedly in his notes.

25. the ermine: (in his notes p. 440 ) Zesen explains his choice of the ermine as a symbol for Joseph (the ermine was depicted in the frontispiece illustration) as follows: “...it is a white little weasel, ... a snow-white little animal which keeps its fur so clean that it would rather die than befoul it. And therefore we have put it together with Joseph on the first copper etching of this book as a symbol of chastity."

26. Selicha...: Zesen's criticism was as follows (p. 442 f.): “... I wonder that Samuel Greiffensohn, ...I know not whence, makes Potiphar a widower who married Sefira, whom he calls Selicha, only after Joseph had already long been in his service."

27. the Persians, Arabs, and others: Grimmelshausen, although probably not competent in any language but his own and thus forced to rely on works in German for all his erudition, nevertheless boasted on the title page of Chaste Joseph that he had consulted "Holy Scripture as well as the books and sagas of other Hebrews, of Persians, and of Arabs." 
28. The Persian Travels of the famous Olearii: Adam Olearius [Oehlschlegel](15991671), who was a member of the trade mission sent by Duke Frederick III of HolsteinGottorp to Persia by way of Moscow (1633-35), published in 1647 an account of the journey under the title Offt begehrte Beschreibung Der Newen Orientalischen Reyse. From the title used by Grimmelshausen it seems probable that he was familiar with the second edition of the work, which was entitled Vermehrte Newe Beschreibung der Muscowitischen vnd Persischen Reyse (1656), or one of two later editions (1661, 1663), both of which mention Persia in the title. No reference to Selicha is made in this work, but in another of Olearius' works, Persianischer Rosenthal (1654), which was a German translation of the works of the Persian poet Shikh Saadi, Olearius does mention in a footnote that according to the Persians Potiphar's wife was named "Selicha" (Book I, Chapter 40, Footnote a, p. 40 in the 1654 edition). It seems likely that in his researches for Chaste Joseph Grimmelshausen used a volume in which the Persianischer Rosenthal was bound together as a second work with the more famous Vermehrte Newe Beschreibung.

29. had talked more than was otherwise his wont: Grimmelshausen wishes to present the mature Simplicissimus as a wise and thoughtful man who remains silent unless he has something really important to say. Old Simplicissimus' taciturnity is also stressed in Heedless Hopalong, Chapter 3.

30. dicentes: statements, utterances.

31. ram's horn...Buckhorn Inn: in the German the first inn has the sign of a black horse (German Rappe) while the second one has the sign of a raven (German Rabe, dialect form Rappe); the first inn, however, is called zum schwarzen Rößl, not zum Rappen, as young Simplicissimus assumes, while the second inn is named zum Rappen, which old Simplicissimus had designated in his letter as the meeting place.

\section{CHAPTER 16}

1. "Will God not see it?...: the omnipresence and omniscience of God is emphasized repeatedly in the Bible and was, of course, a favorite topic treated in sermons and in popular religious literature. Grimmelshausen may have been reminded of it by Balthasar Schupp's advice to his son in Friend in Need (p. 55), which he mentions above (see Chapter 4, note 7): "if you wish to lay the proper fundament to true wisdom, then always remember that God is with you and sees, hears, and understands everything 
you do, speak and think... God's eyes, however, are brighter than the sun and see everything which happens in the dark and in hidden nooks and crannies." Aegidius Albertinus (1560-1620), in his Hirnschleiffer, which Grimmelshausen mentions by name in Proud Melchior and from which he borrowed several longer passages for The Satirical Pilgrim, expatiates on the same theme (p. 218): "When, because of lust and desire, I say to my lecherousness, 'Perhaps the darkness has hidden me', then I am already caught, for, $\mathrm{O}$ Lord, in Thy eyes the night is like a burning torch which shows Thee my sins and betrays me, for darknesses are not dark before Thee." Albertinus later returns to this theme and discourses on it at greater length (pp. 248-252), citing numerous passages from the Bible and the legend of St. Paphnutius.

2. that pious monk...: not St. Paphnutius, as most annotators of The Wondrous Bird's Nest have assumed, but St. Ephraem, as Ilse-Lore Konopatzki asserts in Grimmelshausens Legendenvorlagen (Berlin: Schmidt, 1965 ["Philologische Studien und Quellen,” vol. 28]), p. 68 f. Konopatzki is in error, however, when she assumes that Grimmelshausen could only have encountered this legend in a Latin work, Vitae patrum; he probably was familiar with it from the German translation of Juan Luis de Cerda's famous work, which Aegidius Albertinus translated and published in 1605 under the title Weiblicher Lustgarten, where it is recounted (p. $31 \mathrm{f}$.) immediately before the Paphunutius legend.

3. Sequitur nocentes victor a tergo Deus: Seneca (c. 4 B. C. - 65 A. D.), the famous Roman playwright; the verse is found in Hercules furens (line 385) in Megara's speech to Lycus, where it reads: "sequitur superbos ultor a tergo deus" (an avenging god pursues the proud) Grimmelshausen probably borrowed not only the misquoted line but also its translation and the reference to its location, but the source has not been identified.

4. the holy Apostle...: St. Paul in Romans 13:12-13 admonishes: "The night is far from spent, the day is at hand: let us therefore cast off the works of darkness, and let us put on the armor of light. Let us walk honestly, as in the day; not in rioting and drunkenness, not in chambering and wantonness; not in strife and envying."

5. for he who does evil...: a reminiscence from John 3:19-20: "And this is the condemnation, that light is come unto the world, and men loved darkness rather than light, because their deeds were evil. For everyone that doeth evil hateth the light..." 


\section{NOTES}

6. that noble Roman...: Velleius Paterculus, in his Historiae Romanae, Book II, Chapter 14, tells this anecdote about M. Livius Drusus (assassinated 91 B.C.). The source from which Grimmelshausen took the anecdote has not been identified.

\section{CHAPTER 17}

1. N. N.: see Chapter 15, note 4 .

2. ex officio: by virtue of [his] office.

3. Abraham's words...: Luke 16:29. The chapter concerns Lazarus and the rich man.

4. Breslau or Striegau beer: see Chapter 12, note 5.

\section{CHAPTER 18}

1. the Swedish war: that part of the Thirty Years' War which began with Gustav Adolf's entry into the war in 1630.

2. the Swabian lad's first request is in Westphalian dialect, but in his second he lapses into his native Swabian dialect, that of Ulm and environs.

3. Charles IV of Lorraine and the Count Palatine...: Charles IV of Lorraine and Karl Ludwig, Count Palatine, were at war from 1668 until early 1669.

4. good Monsieur Raphanus: Raphanus is Latin for "radish"; Grimmelshausen may have that member of the radish family in mind which is called Raphanus raphanistrum, "wild radish," which is extremely difficult to root out and control. It is possible that he is also poking fun at the then popular fashion of changing a German surname into its Latin equivalent, for no reason but to impress others. The tale of the encounter with the wolf is similar to that which Franco Sacchetti (c. 1330-c. 1400) tells about one Piero Brandani of Florence in Novella No. 17 of II Trecentonovelle.

5. Ariosto...: Grimmelshausen took both the Italian verses and the German translation of them verbatim from Garzoni, Discourse No. Sixty Two, "On Life at Court" (p. 415). This is why the second line of the Italian, which is misquoted by Garzoni, does not scan; in its correct form it is the perfect hendecasyllable one would expect to find in Ariosto's terza rime: "Se ben dicesse, c'ha veduto il giorno." The tercet is found in Ariosto's First Satire, 11. 10-12. 


\section{CHAPTER 19}

1. a terrible sin, such as cries to Heaven: bestiality was doubtless a matter of some concern and discussion in and around Strasbourg at the time Grimmelshausen was probably writing this episode. Theatrum Europaeum (vol. 10, p. 402) reports, among the heinous crimes perpetrated during the year 1670, the following: "In Strasbourg two sodomites were executed and afterwards burned. The first was a man of some sixty-odd years who is said to have frequently had to do with very small children; the other a lad of sixteen or seventeen years who had to do with a horse, which was burned with him."

2. Show thyself to the priest: the command is not meant to assert that the shepherd is a Catholic, for the narrator is quoting Matthew 8:4, in which Jesus, after healing the leper, instructs him on what he should do next.

\section{CHAPTER 20}

1. little songbird: the contrasting of man, who despite his reason is heedless, and the birds and other animals, who despite the lack of reason and of an immortal soul, act more reasonably than man was a well-known and favorite theme of the time. Pierre Boaistuau de Launay (d. 1566), for example, wrote at length on the subject in his Le Theatre $d u$ Monde (four-language edition of 1619, p. 88 ff.), to which Grimmelshausen alludes in The Satirical Pilgrim and from which he borrowed nearly verbatim the list of birds and animals he cites in a similar argument in Simplicissimus II, 12. In Continuatio, Chapter 23, Simplicissimus, alone on an island and deprived of books to read, also finds in observing nature constant reference to the precepts of the Christian religion.

2. I also learned...: Grimmelshausen here manages to include all of the Seven Deadly Sins, in the following order: Pride, Gluttony, Envy, Rage, Lust, Avarice, and Sloth. The serpent, the dragon of hell, is spoken of in Revelations 12:1-9.

3. accursed Satan...: a reminiscence of I Peter 5:8: "Be sober, be vigilant; because your adversary the devil, as a roaring lion, walketh about, seeking whom he may devour."

4. She is enjoining you to praise your Creator: the first and most famous occurrence of this notion in Grimmelshausen's works is found in Simplicissimus I, 7, in the song of the anchorite: 
Come, balm of night, thou nightingale, Come, let thy dulcet tones regale The world with joyous singing. Come, praise Him who made me and thee, For others, sleeping peacefully, Have put aside their singing. So lift thy voice now, Sweet and clear, in songs of cheer, In songs of love To our Lord God in Heav'n above!

And though the sun no longer shines, Though darkness now the world confines, We still shall keep on singing Of God's beneficence and might, So that in even dark of night His praises still are ringing.

So lift thy voice now, etc.

And echoes, ringing through the dale, Now wish to join thee, nightingale, And let God hear their ringing. They frighten mortal sleep away, To which we are in thrall each day, So we can hear them singing.

So lift thy voice now, etc.

The stars in heaven, shining bright, Are praise to God this starry night, To Him they're honor bringing. The owl, who cannot sing at all, Proves by her rasping, hooting call: God's praise she too is singing. So lift thy voice now, etc.

So come, my darling little bird, And we shall show by song and word; To sleep we'll not be clinging! For till the dawn comes fresh and clear, O'er these dark virgin forests here God's praises we'll keep singing! So lift thy voice now, etc. 
5. a broken spirit and a contrite heart...: see Psalm 51:17: reminiscences of this psalm are particularly appropriate, for it is "a psalm of David, when Nathan the prophet came to him, after he had gone unto Bathsheba."

6. Arise, go quickly...: the passage contains several borrowings from Psalm 51.

7. the horse of Sejanus: Aulus Gellius tells in his Noctes Atticae, Book III, Chapter 9, of a prominent Roman named Cnaius Sejus who had a horse which was supposed to be a descendant of the horse of Diomedes. The animal was extremely beautiful but had the property of bringing misfortune upon whoever owned it. Sejus was banished and later killed; the next owner of the horse was murdered; and the next two owners also died under most unfortunate circumstances. The horse of Sejus thus came to be looked on as a bringer of bad luck.

8. what a great calamity...: this is precisely what happens with it in The Wondrous Bird's Nest, Part II.

9. seventeen hundred pieces: see Chapter 14 , note 3 .

10. Solomonis proverb...: Proverbs 6:6; it continues "consider her ways and be wise."

11. there came a pack of wolves...: the wolves are phantoms of hell; Hopalong too was besieged by wolves and forced to climb to safety (on a rooftop), but these wolves were anything but immaterial (see Heedless Hopalong, Chapters 16 and 17). Grimmelshausen also links wolves and greed in the scene in Continuatio, Chapter 3, in which Avarice appears riding on a wolf.

12. basilisci: basilisks; the basilisk was a legendary reptile whose breath and gaze were fatal.

13. the thousand double ducats...: see Heedless Hopalong, Chapter 24.

14. Amadis: this romance of chivalry, full of erotic love stories, originated in Spain, became popular in France, and appeared in German translation in 1583. Grimmelshausen, like Moscherosch, considers it a worthless but dangerous book (see The Runagate Courage, Chapter 5). 



\section{Bibliography}

\section{German Editions of Grimmelshausen's Works}

\section{Das wunderbarliche Vogelnest}

Grimmelshausens Wunderbarliches Vogelnest, Erster Teil. Abdruck der ältesten Originalausgabe (1672) mit den Lesarten der anderen zu Lebzeiten des Verfassers erschienenen Ausgaben. Edited by J. H. Scholte. ("Neudrucke deutscher Literaturwerke des XVI. und XVII. Jahrhunderts," Vols. 288-291.) Halle: Max Niemeyer Verlag, 1931.

Das wunderbarliche Vogelnest. Edited by Rolf Tarot. (Gesammelte Werke in Einzelausgaben). Tübingen: Max Niemeyer Verlag, 1970.

\section{Works}

Hans Jacob Christoffels von Grimmelshausen Simplicianische Schriften. Edited by Heinrich Kurz. ("Deutsche Bibliothek," Vols. 3-6.) Leipzig: J. J. Weber, 1863-64.

Grimmelshausens Werke. Edited by Felix Bobertag. ("Deutsche National-Litteratur," Vols. 33-35.) Berlin and Stuttgart: W. Spemann, $1882 \mathrm{ff}$.

Grimmelshausens Werke in 4 Teilen. Edited by H. H. Borcherdt. Berlin: Bong, 1921.

Die Simplicianischen Schriften des Hans Jacob Christoffel von Grimmelshausen. Monumentalausgabe in zwei Bänden. Edited by Franz Riederer. Naunhof bei Leipzig: F. W. Hendel, 1939. 
Der abenteuerliche Simplicissimus and Simplicianische Schriften. Edited by Alfred Kelletat. ("Werke der Weltliteratur in Dünndruckausgaben," Vols. 21 and 41.) Munich: Winckler, 1956/1958.

Grimmelshausens Werke in vier Bänden. Edited by Siegfried Streller. Berlin and Weimar: Aufbau Verlag, 1960.

\section{Other Works}

\section{Important Scholarly Treatments of Das Wunderbarliche Vogel- nest}

Ermatinger, Emil. "Der Weg der menschlichen Erlösung in Grimmelshausens 'Simplicissimus,' 'Courasche' und 'Vogelnest,' in Ermatinger, Emil. Krisen und Probleme der neueren deutschen Dichtung. Aufsätze und Reden. Zurich, Leipzig and Vienna: Amalthea-Verlag, 1928, pp. 105-23.

Jöns, Dietrich. "Emblematisches bei Grimmelshausen," Euphorion, Vol. 62 (1968), pp. 385-91.

Kienast, Johann. J. J. Chr. von Grimmelshausen. "Das Vogelnest I. und II." University of Vienna Dissertation (unpublished), 1937.

Negus, Kenneth. Grimmelshausen. ("Twayne's World Authors Series," Vol. 291.) New York: Twayne Publishers, Inc., 1974. (pp. $121 \mathrm{ff}$.)

Scholte, J. J. “Der Sinn des Wunderbarlichen Vogelnests," Euphorion. Vol. 32 (1931), pp. 141-45.

Wagener, Hans. "Perspektiven und Perspektivismus in Grimmelshausens Wunderbarlichem Vogelnest." German Quarterly. Vol. 69 (1976), pp. 1-12. 


\section{Works Cited in the Notes}

Albertinus, Aegidius. Aegidii Albertini Hirnschleiffer. Cologne: Constantinus Münich, 1645.

Bebel, Heinrich. Heinrich Bebels Facetien. Drei Bücher. Edited by Gustav Bebermeyer. ("Bibliothek des literarischen Vereins in Stuttgart,” Vol. 276.) Leipzig: Verlag Karl W. Hiersermann, 1931.

Bechtold, Arthur. Johann Jacob Christoffel von Grimmelshausen und seine Zeit. Munich: Musarion Verlag, 1919.

Boaistuau-de Launay, Pierre. Le Theatre du Monde.... [four-language edition] Cologne: Jean de Tournes, 1619.

Bolte, Johannes. "Die ältesten Fassungen des Schwankes vom Kuhdiebe," Archiv für das Studium der neueren Sprachen und Literaturen, Vol. 113 [N. F. 13] (1904), pp. 17-30.

Cerda, Juan de la. Weiblicher Lustgarten.... Translated by Aegidius Albertinus. Munich: Nicholaus Henricus, 1605.

Fastnachtspiele aus dem fünfzehnten Jahrhundert. Edited by A. v. Keller. ("Bibliothek des literarischen Vereins in Stuttgart," Vol. 28.) Stuttgart: Anton Hiersemann, 1853.

Garzoni, Tomaso. Piazza universale. Das ist: Allgemeiner Schawplatz / oder Marckt / und Zusammenkunfft aller Professionen / Künsten / Geschäfften / Händeln und Handwercken / so in der gantzen Welt geübet werden:...Frankfurt am Main: Lucas Jennesius, 1626.

Haberkamm, Klaus. "Sensus Astrologious." Zum Verhältnis von Literatur und Astrologie in Renaissance und Barock. ("Abhandlungen zur Kunst-, Musik-, und Literaturwissenschaft," Vol. 124.) Bonn: Bouvier, 1972. 
Handwörterbuch des deutschen Aberglaubens. Edited by Hanns Bächtold-Stäubli et. al. 10 vols. Nerlin and Leipzig: W. de Gruyter \& Co., 1927-42.

Hohberg, Wolfgang Helmhard, Freiherr von. Georgica curiosa acta, das ist Umständlicher Bericht und klarer Unterricht von dem adelichen Land- und Feld-Leben... 3 vols. Nuremberg: Martin Endters, 1701-15.

Könnecke, Gustav. Quellen und Forschungen zur Lebensgeschichte Grimmelshausens. Edited by J. H. Scholte. 2 vols. Weimar: Gesellschaft der Bibliophilen, 1926.

Konopatzki, Ilse-Lore. Grimmelshausens Legendenvorlagen. (“Philologische Studien und Quellen,” Vol. 28.) Berlin: Erich Schmidt Verlag, 1965.

Kornmann, Heinrich. Mons Veneris, Fraw Veneris Berg, Das ist, Wunderbare und eigentliche Beschreibung der alten Haydnischen und Newen Scribenten Meinung, von der Göttin Venere... Frankfurt am Main: Matthias Becker / Jacob Fischer, 1614.

Koschlig, Manfred. Grimmelshausen und seine Verleger. ("Palaestra," Vol. 218) Leipzig: Akademische Verlagsgesellschaft m. b. H., 1939.

- Das Ingenium Grimmelshausens und das 'Kollektiv.' Studien zur Entstehungs- und Wirkungsgeschichte des Werkes. Munich: Verlag C. H. Beck, 1977.

Lauremberg, Peter. Acerra philologica. Das ist: Vierhundert außlerlesene Nützliche, lustige, und denckwürdige Historien und Discursen... Leyden: Frantz Heger, 1646. 
McKee, David Rice. "Isaac de La Peyrère, a Precursor of EichteenthCentury Critical Deists," PMLA, Vol. 59 (1944), pp. 456-485.

Meister Altswert. Meister Altswert. Edited by W. Holland and A. Keller. ("Bibliothek des literarischen Vereins in Stuttgart," Vol. 21.) Stuttgart: Literarischer Verein, 1850.

Moscherosch, Hans Michael. Visiones de Don de Quevedo. Das ist: Wunderliche und warhafftige Gesichte Philanders von Sittewald... Grankfurt: Johann Gottfried Schönwetter, 1645-48.

Olearius, Adam. Persianischer Rosenthal.... Vor 400. Jahren von einem Sinnreichen Poeten Schich Saadi in Persischer Sprach beschrieben.... Translated by Olearius and "a Persian named Hakwirdi.” Schleswig: Johann Holwein, 1654.

- Vermehrte Newe Beschreibung Der Muscowitischen vnd Persischen Reyse... Schleswig: Johan Holwein, 1656.

Paracelsus, Theophrastus Bombast von Hohenheim. Four Treatises of Theophrastus von Hohenheim, called Paracelsus. Translated by C. L. Temkin, George Rosen, Gregory Zilboorg, and Henry E. Sigerist. Edited by Henry E. Sigerist. Baltimore: The Johns Hopkins Press, 1941.

Pauli, Johannes. Schimpf und Ernst. Edited by Hermann Österley (“Bibliothek des litterarischen Vereins in Stuttgart," Vol. 85.) Stuttgart: Litterarischer Verein, 1866.

- Schimpf und Ernst. Edited by Johannes Bolte. 2 vols. Berlin: Herbert Stubenrauch Verlagsbuchhandlung, 1924.

Rosset, François. Herrn Frantzen von Roßet Wunderlich und Trawrige Geschichten. Durch Martin Zeillern Auß dem Frantzöslschen verteütscht... (earlier editions were entitled Theatrum Tragicum) Ulm: Johann Görlin, 1655. 
Sacchetti, Franco. II Trecenfonovelle. Edited by Emilio Faccioli. Turino: Giulio Einaudi, 1970.

Scholte, J. H. Probleme der Grimmelshausen-Forschung. Groningen: Wolters, 1912.

- Der Simplicissimus und seln Dichter. Tübingen: Max Niemeyer Verlag, 1950.

- Zonagri Discurs von Waarsagern. Ein Beitrag zu unserer Kenntnis von Grimmelshausens Arbeitsweise... ("Verhandelingen der koninklijke Akademie van Wetenschappen te Amsterdam, Afdeeling Letterkunde," New Series, Vol 22.) Amsterdam: Johannes Müller, 1921.

Schupp, Johann Balthasar. Streitschriften. Zweiter Teil. Abdruck der jeweils ältesten Ausgaben mit den Varianten der Einzeldrucke und der ältesten Gesamtausgabe deutscher Schriften. Edited by Carl Vogt. ("Neudrucke deutscher Litteraturwerke des XVI. und XVII. Jahrhunderts," Vols. 225-227.) Halle: Max Niemeyer, 1911. [contains J. B. Schuppii D. Deutscher Lucianus]

. Der Freund in der Not. Abdruck der ersten Ausgabe (1657). Edited by Wilhelm Braune. ("Neudrucke deutscher Litteraturwerke des XVI. und XVII. Jahrhunderts," Vol. 9.) Halle: Max Niemeyer Verlag, 1878.

Theatrum Europaeum... 20 parts. Frankfurt am Main: various publishers, 1662-1734.

Weydt, Günther. Nachahmung und Schöpfung im Barock. Bern and Munich: Francke Verlag, 1968.

Zesen, Phillip von. Assenat (1770). Edited by Volker Meid.

(“Deutsche Neudrucke, Reihe Barock," Vol. 9.) Tübingen: Max Niemeyer Verlag, 1967. 